\title{
الوطن بين هلدي القرآن وضلالات الأفهام
}

$$
\text { إعداد }
$$

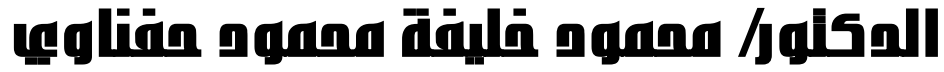

أستاذ التفسير وعلوه القرآن المساعد بقسه أصول الدين

كليت العلوم الإسلاميت الأزهريت للطلاب الوافدين بالقاهرة 


\section{|المقدمة}

الحمد الله رب العالمين، والصلاة والسلام على أشرف المرسلين،،، وبعد

فإن حب الوطن من الأمور التي حبى الله تعالى بها الفطر السليمة، وأولى بها العقول المستقيمة، فهو موضع الميلاد، ومضجع الآباء والأجداد، هواؤه أول هواء حرك الرئتين، وترابه أول تراب مس الراحتين، وشعاع شمسه أول شعاع اغترف العينين، مجرى الصبا وملعبه، وعرس الثباب ومو كبه، ومراد الرزق ومطلبه، وطريق

预. rTo الججد ومركبه، فهو النعمة القريبة للإنسان، ففيه مستقر حياته ومحل ميلاده، ومكان عرضه ومكمن شرفه. أولاه القر آن عناية فائقة، فذكره في غير موضع منه، بين آية تصرح وأخرى تلمح، والغاية واحدة إذ كان حب الأوطان من الإيمان.

وعلى هدي القرآن سارت السنة النبوية المطهرة، وباين هذين الهدي الشريف - هدي القر آن الكريم والسنة النبوية - ضلال أناس رأوا من الوطن صنما يعبد، وحفنة تراب لا قيمة لها تذكر، وغفلوا عن كونه جوهرة شريفة يجب أن تحفظ، وقطعة تبر يتنسم الإنسان من خلالها عبير الأمن والأمان. لأجل ما سبق جاء هذا البحث الذي يصور نظرة القر آن الكريم - دستور الأمة الإسلامية وكتابها الخالد - إلى الوطن عل من يقف على هذه الحقيقة يرعوي عن غيه، ويئوب إلى رشده، فجاء عنوان البحث "الوطن بين هدي القر آن وضلالات

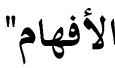 \\ أسباب اختثيار الموضنوع} هذا وقد دفعني إلى الكتابة في هذا الموضوع بالإضافة إلى ما سبق:

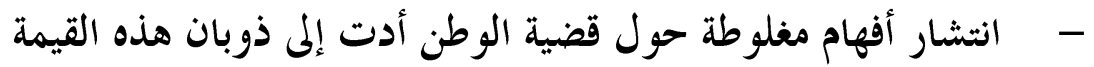
وتلاشيها أمام فهوم عقيمة حينا وتقدمية حينا آخر. 
- - - الصراع الفكري المنتشر بين الأوساط العلمية والثقافية حول قضية

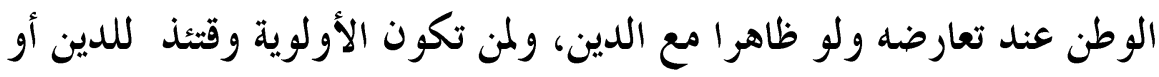

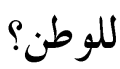

-دعوة بعض الجماعات والطو ائف والفرق المنتشرة في زماننا هذا إلى تنحية فكرة

الوطن، وتجنيها تماما وتغليب فكرة الصراع بين الدين والوطن جهات ولها منهم

بمكانة الوطن من الدين

- شطط بعض الفهوم في تقديم فكرة الوطن على سائر المقدمات التي يدين الإنسان

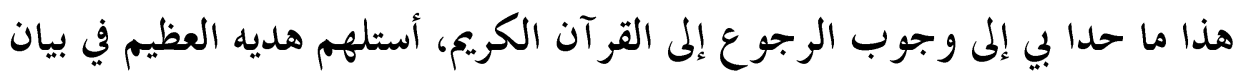

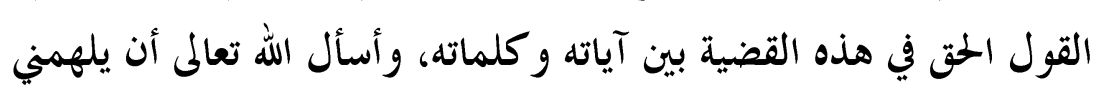

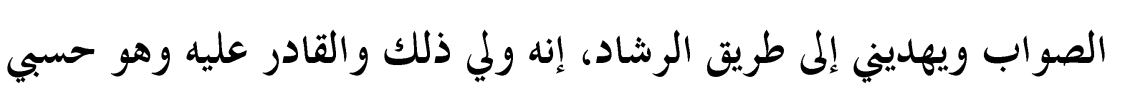

\section{خطة البحث}

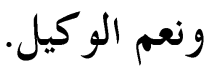

rut

أما عن الخطة التي توصلت إلى مقصودي من هذا البحث من خلالها فقد اشتملت على :مقدمة وتمهيد وفصلين وخحاتمة

المقدمة: واشتملت على البسملة والحمدلة والتصلية على البي محمد صلى ولى الله

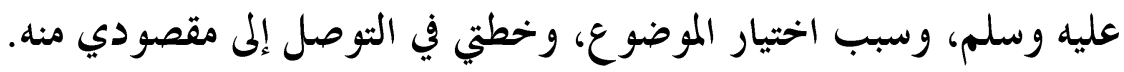

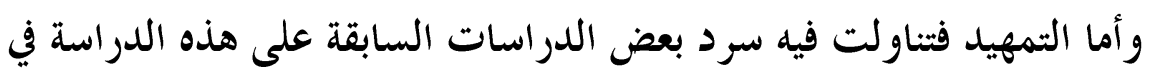
ذات الموضوع، وأهمية هذه الدراسة بين هذه الدراسات.

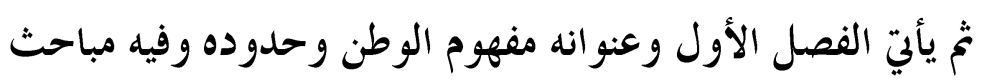
المبحث الأول: مفهوم الوطن لغة واصطلاحا. المبحث الثالي: مرادفات الوطن في اللغة. المبحث الثالث: حدود الوطن وأقسامه وشروطه ونو اقضئ. مراته. 
المبحث الرابع: صور التعبير عن الوطن في القر آن الكريم. المبحث الخامس: مأثورات في مكانة الوطن عند الأمم والصالحين. ثم الفصل الثاني وعنوانه: الوطن بين هدي القر آن وضلالات الأفهــام وفيـــهـ تسعة مباحث

المبحث الأول: تباين الأفهام في معنى الوطن. المبحث الثالي: الوطن حق للإنسان. المبحث الثالث: الوطن نعمة من نعم الله تعالم.

势 rT

$\frac{\overline{3}}{3}$

المبحث الرابع: الموازنة بين الدين والوطن.

المبحث الخامس: الحرمان من الوطن عقوبة. المبحث السادس: الخروج من الوطن قرين القتل والعذاب. البحث السابع: هجرة الوطن بين الثواب والعقاب. المبحث الثامن: مشروعية الدفاع عن الوطن المبحث التاسع: موقف الأنبياء من الوطن ثم الخاتمة وتنضمن أهم النتائج التي تمخض عنها البحت البحث التمبمديد

$$
\text { وفيه الحديث عن }
$$

- - - الدراسات السابقة على هذه الدراسة.

- - - أهمية هذه الدراسة بين هذه الدراسات.

\section{أولا: اللدراسات السابقة على هذه الدراسلة}

لم تكن هذه الدراسة التي نحن بصددها هي البادرة الأولى في موضوع الـــوطن،

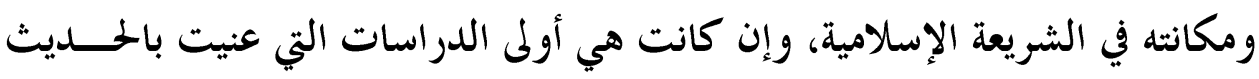

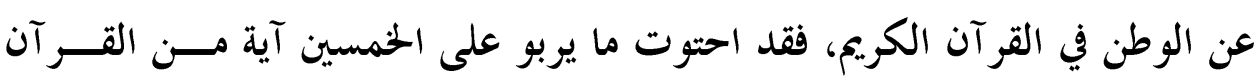
الكريم التي تحدثت تصريحا أو تلميحا في موضوع الوطن، وقد سبقت هذه الدراســـة 
بجمع غير قليل من المؤلفات التي تحدثت في موضوع الوطن، والتزوع إليه ومكانتسه. من الدين، وأخص من هذه الدراسات ما يلي:

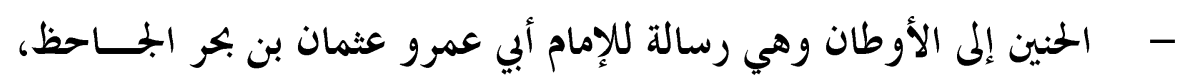

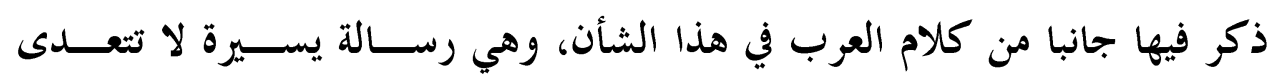

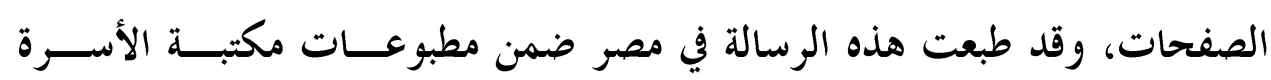
199 ام بتحقيق الأستاذ عبد السلام هارون.

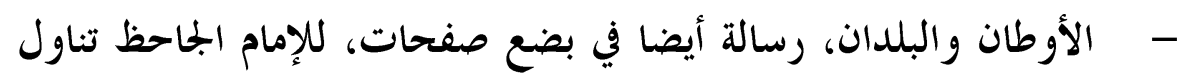

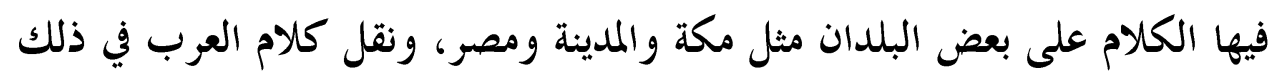

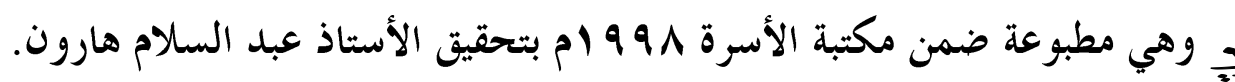

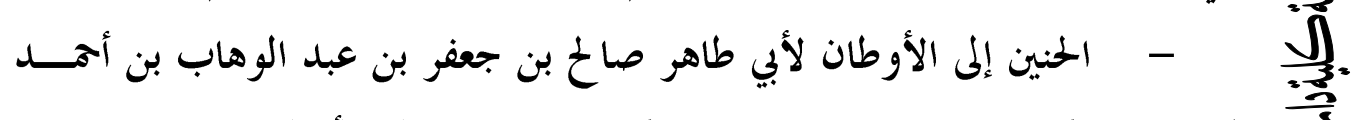
يرج

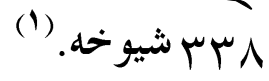

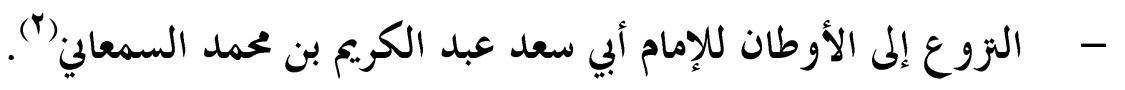

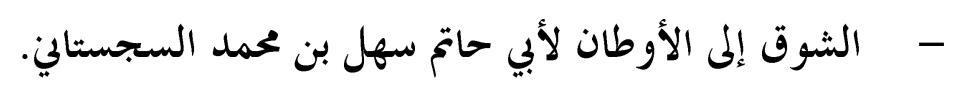
$\overline{3}$

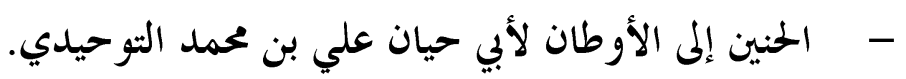

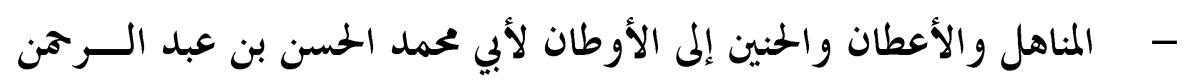
بن خلاد الرامهرمزي.

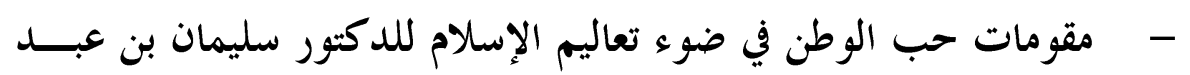
الله بن محمود أبا خليل. - حب الوطن من منظور شرعي للدكتور زيد بن عبد الكريم الزيد. - - الوطن والاستيطان دراسة فقهية للدكتور محمد بن موسى بن مصطفي الدالي. 
فهذه بعض المؤلفات التي تناولت الوطن بالدراسة، غير أن أغلبـــها مفقـــود

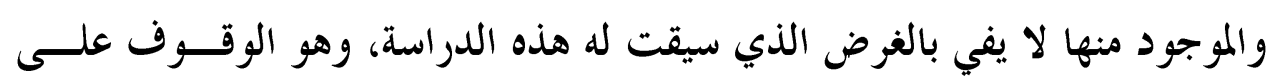
آيات الكتاب الكريم التي تصرح أو تلمح بقيمة أو مكانــة الـــوطن في الثــــريعة الإسلامية، ومن هنا جاءت أهمية هذه الدراسة.

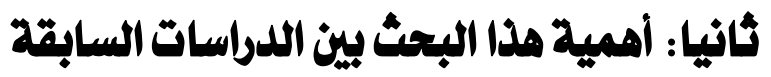

$$
\text { تكمن أهمية هذا البحث في: }
$$

- - يساهم هذا البحث في الوقوف على المكانة الحقيقية للوطن في ضوء القــــر آن

势 الكريم مقارنا ببعض الفهوم السائدة.

- - يساهم هذا البحث في الرد على الفهوم الباطلة تجاه قضية الوطن والتي تجني البشرية بمعاء الثمار المرة لمذه الفهوم.

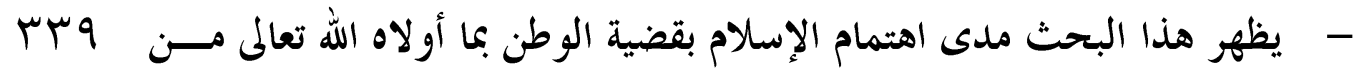

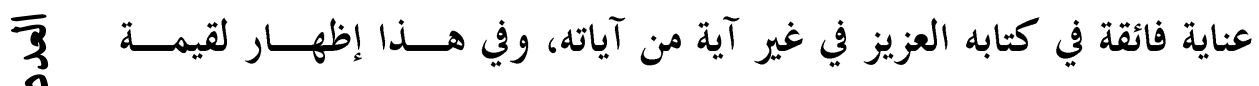

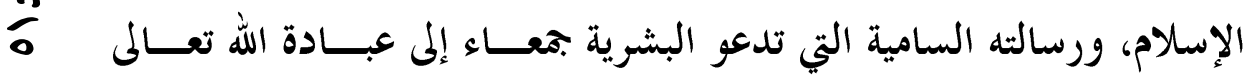

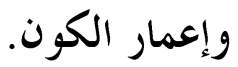

- يقف هذا البحث على خمسين آية من التبزيل تكلمت عن موضوع الوطن.

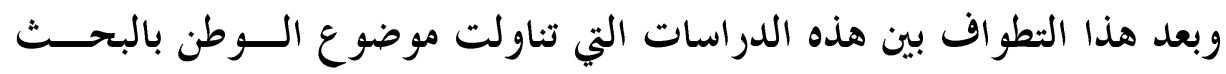
والدراسة هذا أوان الثروع في المقصود بعون الله تعالى المعبود. 


\section{الفمل الأول : مفهوم الوطن وحدوده}

\section{وفيه أربعة مباحث}

المبحث الأول: تعريف الوطن لغة واصطلاحا

$$
\text { المبحث الثالي: مرادفات الوطن في اللغة }
$$

المبحث الثالث: حدود الوطن أقسامه وشروطه ونواقضه

المبحث الرابع: صور التعبير عن الوطن في القر آن الكريم

\section{المبحث الأول: تعريف الوطن لغلة واصطلاحما:}

أولا: التعريف اللغوي

تعددت أقوال اللغويين في معنى الوطن، وكلها تدور حول معنى الإقامة بالمكان

قال ابن منظور: الوطن المنزل تقيم فيه، وهو موطن الإنسان ومحله، والجمـــع

• ع ع أوطان، وأوطان الغنم والبقر مر ابضها وأماكنها التي تأوي إليها.

$$
\text { قال الأخطل: }
$$

كروا إلى قريتكم تعمروها كما تكر إلى أوطانها البقر

ومواطن مكة مواقعها وهو من ذلك، وطن بالمكان وأوطن أقام، وأوطنه اتخذه

وطنا، يقال أوطن فلان أرض كذا و كذا، أي اتخذها محلا ومسكنا يقيم فيه، وأوطنت الأرض ووطنتها توطينا واستوطنتتها أي التخذها وطنا، أما المواطن فكل مقام قام بــهـ الإنسان لأمر فهو موطن له كقولك إذا أتيت فوقفت في تلك المواطن فــادع الله لي

$$
\text { ولإخوالين(T) }
$$

قال الرازي في مختار الصحاح :والموطن المشهد من المشاهد

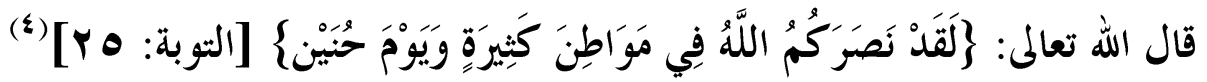
وفي المعجم الوجيز : وطن بالمكان يطن وطنا أقام فيه، وأوطن البلــــد اتخــــهـ وطنا، وواطنه على الأمر وافقه عليه، والقوم عاش معهم في وطن واحد، توطن أقام، 


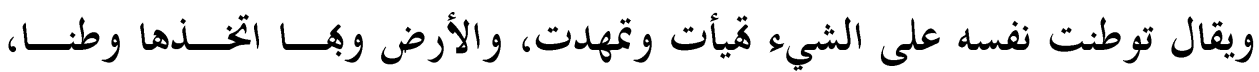

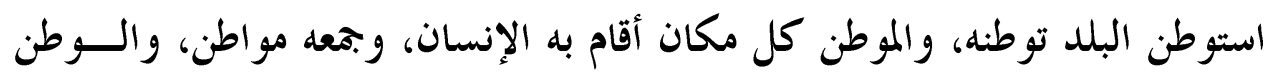

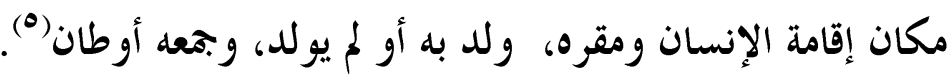

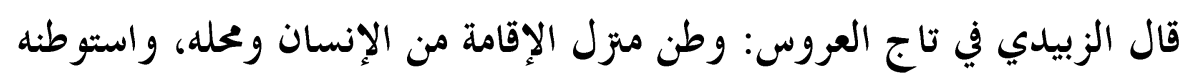
إذا اتخذه محلا ومسكنا يقيم فيه").

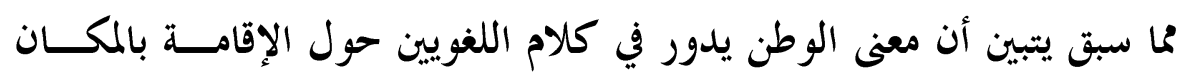

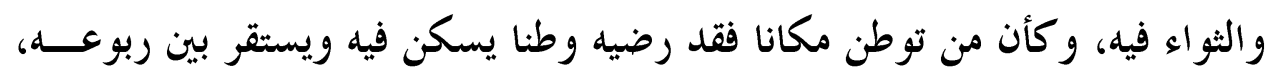

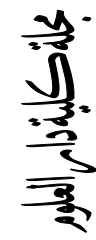
ولد فيه أو لم يولد. ثانيا: التعريف الاصطلاحي

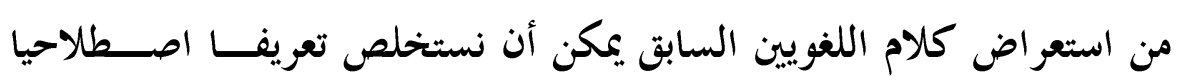

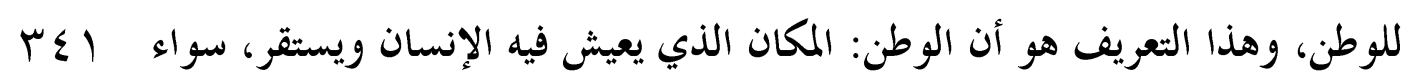

$\overline{3}$

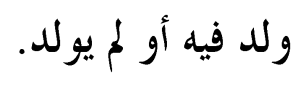

وذلك لأن الاصطلاح هنا لا ينبو عن اللغة، إذ اصطلاح جميع الناس في الوطن

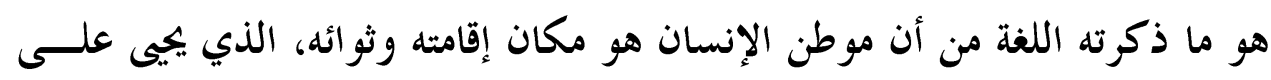
أرضه ويعيش من خيراته ويرتوي من مائه.

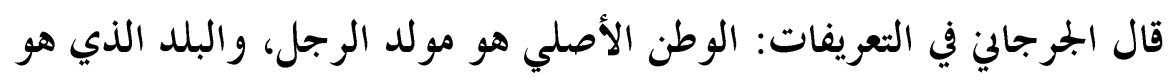
فيه.

ووطن الإقامة: موضع ينوي أن يستقر فيه تخسة عشر يومًا أو أكثر من غير أن

$$
\text { يتخذه مسكنًا (v) }
$$

وفي الموسوعة الفقهية الكويتية قال : وفي الاصطلاح: الوطن هو متزل إقامــة

$$
\text { الإنسان ومقره ولد به أو لم يولد (م) . }
$$




\section{口الإبحثُ الثُاني: مرادضات الوطن في اللغة}

لم يقتصر اللغويون في التعبير عن الوطن على هذه اللفظة فقط، وإنما تعدوها إلى تورة

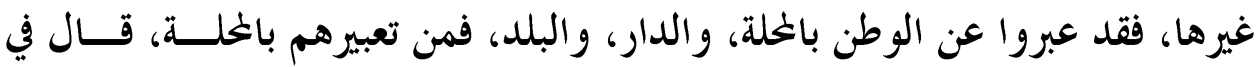

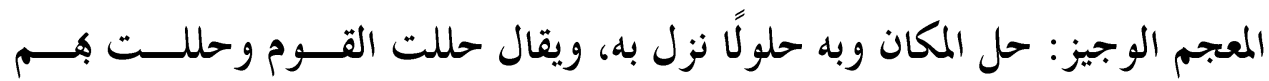

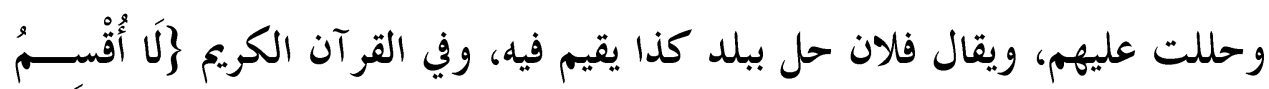

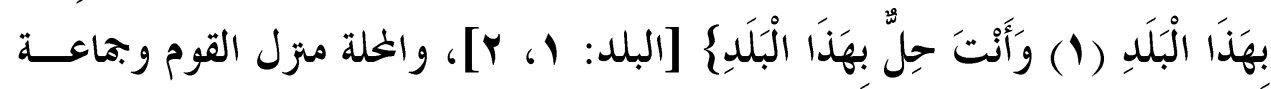
البيوت، ومجتمع الناس، و.جعه محال (9).

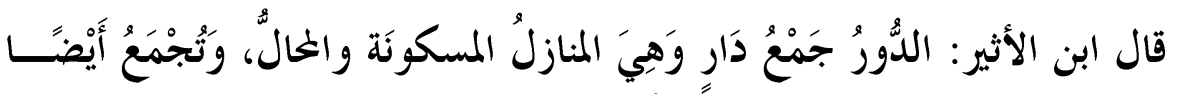

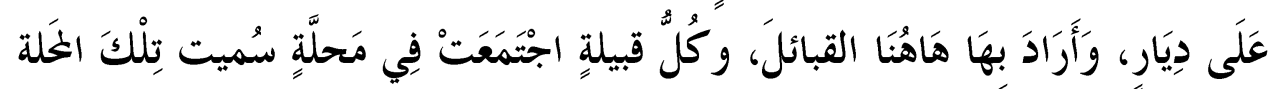

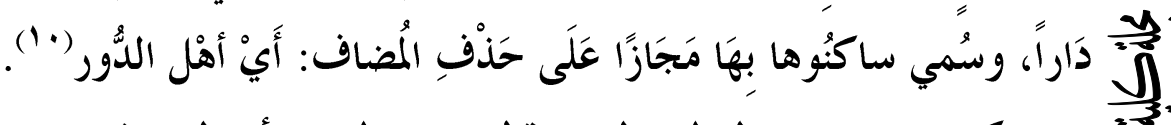

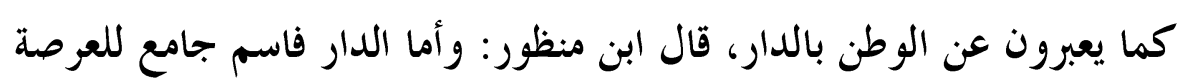
و البناء والخلة، و كل موضع حل فيه قوم فهو دارهم، والدنيا دار الفناء، والآخرة دار

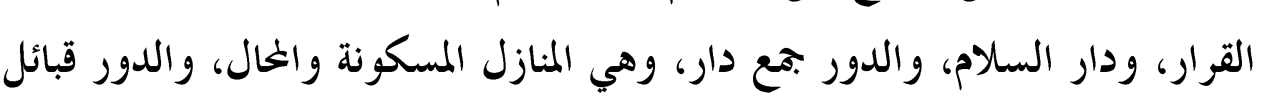

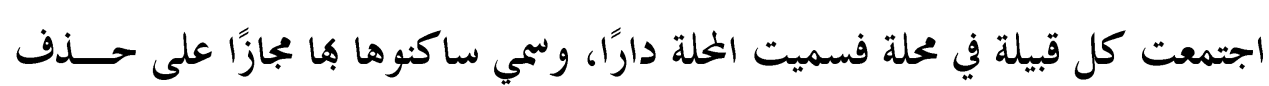
المضاف أي أهل الدور، والدار البلد، حكى سيبويه هذه الدار نعمت البلد، فأتـــت $\overline{3}$
3
0 البلد على معنى الدار، والدار اسم مدينة سيدنًا رسول الله - صلى الله عليه وسلم -

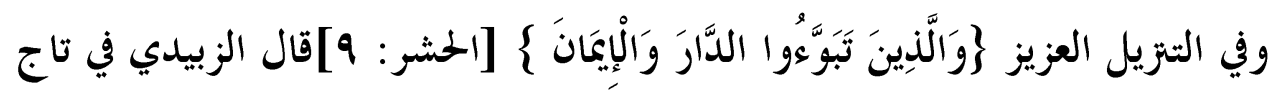
العروس: الخل مجمع البناء، وكل موضع حل به قوم فهو دارهم، والدور هي المنازل

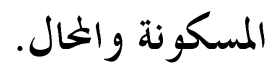

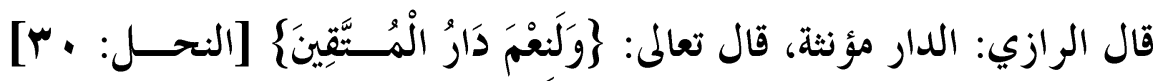

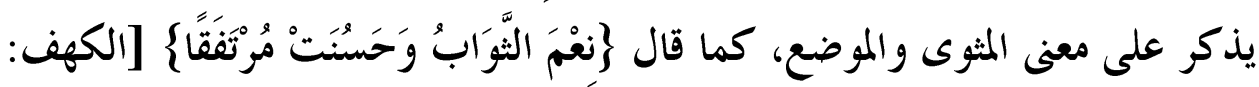

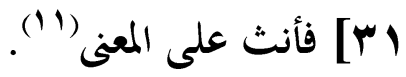




\section{المبحثُ الثَالث: حدود الوطن وأقسامه}

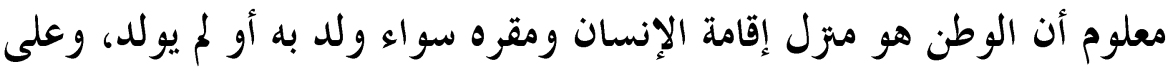

هذا التعريف يمكن أن نقصر الوطن على البلدة أو الخلة التي ولد فيها أو استقر فيها،

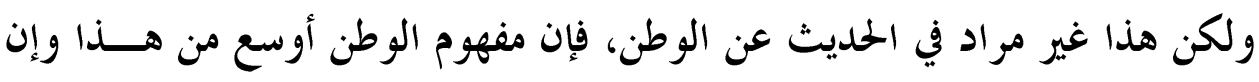
كان يشمل ما سبقت الإنشارة إليه.

فحدود وطن الإنسان تنتهي عند فاية أموره ومصالحه وشئون حياتسه، الــتي

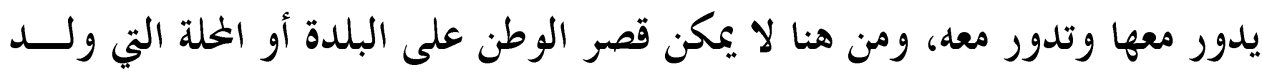

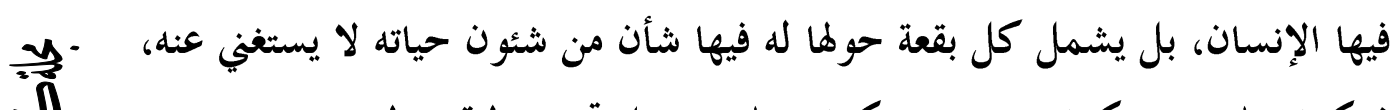

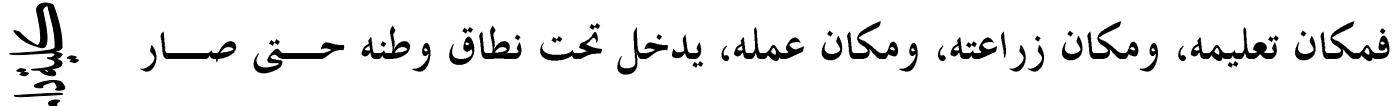
㿣 $r \leqslant \mu$ العرف في هذا الزمان - ومعلوم أن العرف معتبر - أن وطن الإنسان هو البلدة التي يحمل جنسيتها، فهذا مصري، وهذا جزائري، وهذا مغربي، وهكذا.

率

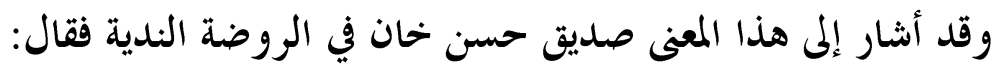

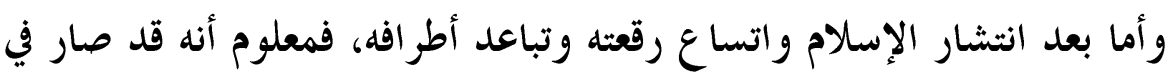

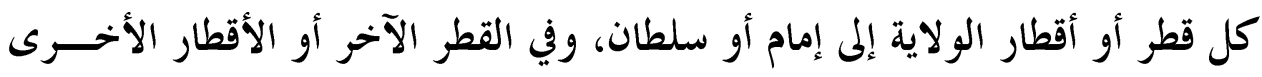

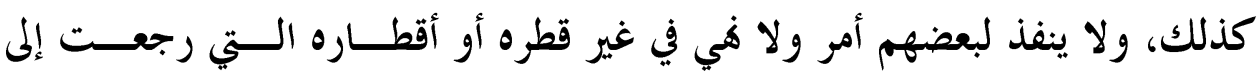

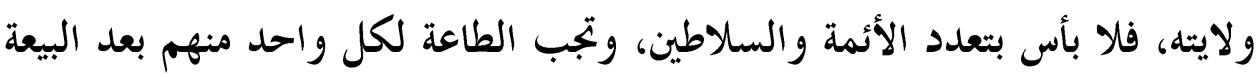

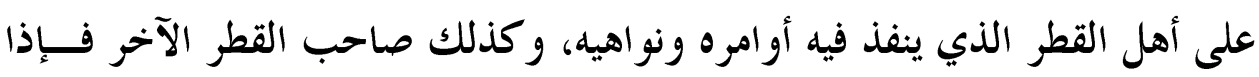

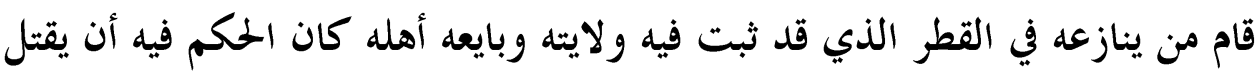

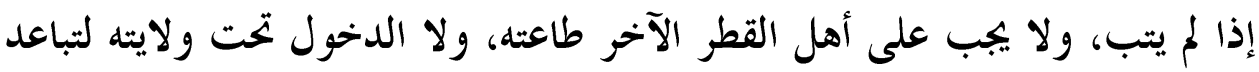

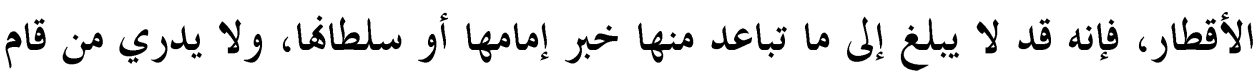

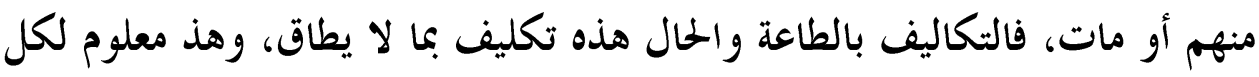

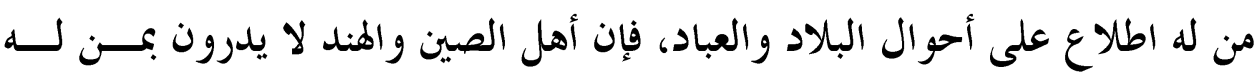

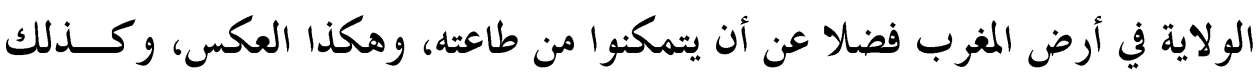


أهل ما وراء النهر لا يدرون بمن له الولاية في اليمن، وهكذا العكس، فاعرف هــذا فإنه المناسب للقو اعد الثرعية والمطابق لما يدل عليه الأدلة، ودع عنك ما يقــال في مخالفته، فإِن الفرق بين ما كانت عليه الولاية الإسلامية في أول الإسلام وما هي عليه

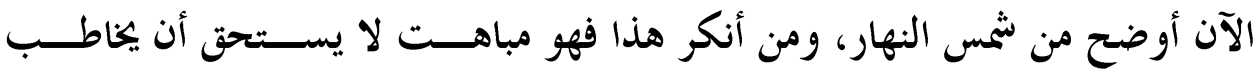

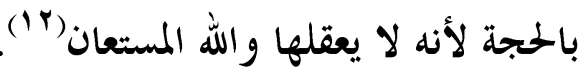
قال محمد رشيد رضا بعد نقل الكلام السابق: وهذ أوجه تفصيل قيل في جواز التعدد للضرورة، وهو اجتهاد وجيه ويشبه عند بعض الأئمة تعدد الجممعة في البلـــد الواحد، فالأصل في الشرع أن يجتمع أهل البلد كلهم في مسجد واحسـد ....وجـــوز التعدد للضرورة بقدرها، سدا لما يعتبره له في حال الاختيار (r"i).

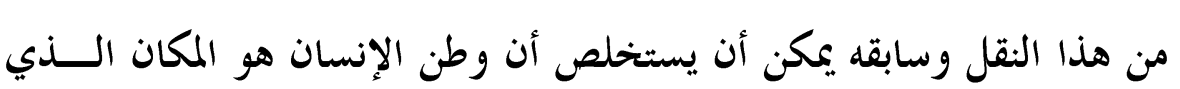

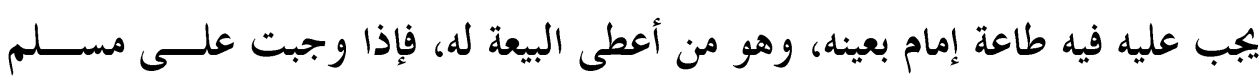
طاعة إمام لقطر بعينه فهذا القطر بأكمله له وطن، وعليه فقد قسم العلماء الوطن إلى لى ए $\leqslant \varepsilon$ أقسام نظرا لما يترتب علي معرفته من أحكام شرعية، تأتيك في الصفحات الآتية. ثانيا: أقسام الوطن سبق أن ذكرنا أن الوطن في الشريعة الإسلامية تناط به أحكام كثيرة منها قصر الصلاة، والإفطار في السفر، والإعفاء من الأضحية، وسقوط التكليــف بالجمعــة،

ولأجل هذا قسم الفقهاء الوطن إلى ثلاثة أقسام :

الوطن الأصلي ووطن الإقامة ووطن السكنى أمـــا الـــوطن الأصــلي فتــــال الثرنبلالي: والوطن الأصلي هو الذي ولد فيه وتزوج أو لم يتزوج وقصد التعيش لا الارتحال عنه، ووطن الإقامة موضع نوى الإقامة فيه نصف شهر فما فوقه. قال: ولم يعتبر الخققون وطن السكنى وهو ما ينوي الإقامة فيسـه دون نصــف 
وقال الرعيني: الوطن هو محل سكنى الثخص بنية التأبيد، وموضع الزوجــة المدخول بها وإن لم يكثر سكناه عندها (10).

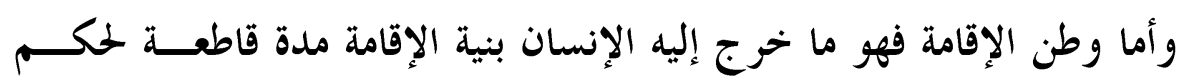
السفر، ويسمى بالوطن المستعار، أو بالوطن الحادث.

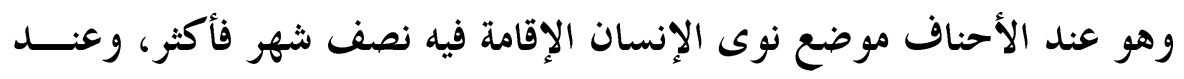
غيرهم خلاف في المدة القاطعة لحكم السفر، وعليه كلام الشرنبلالي السابق.

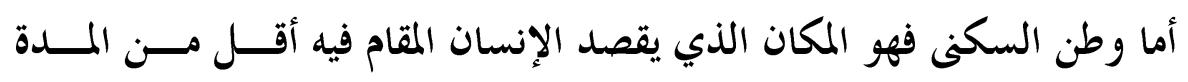

氛 $\mu \leqslant 0$

$\overline{3}$

القاطعة للسفر (14).

$$
\text { المبحث الرابع: شروط الوطن ونو اقضه لمان }
$$

ويشرط للوطن الأصلي أن يكون مبنيا بناء مستقر المبا جرت العرنه العادة بالبناء به، وهذا عند الثافعية والحنابلة والمالكية.

وعند الأحناف هو المكان الذي ولد فيه الشخص أو تأهل فيه أو توطن فيسه. وطنا أصليا له. ويشترط في وطن الإقامة نية الإقامة، ومدة الإقامة المعتسبرة، واتخــاذ مكسـان

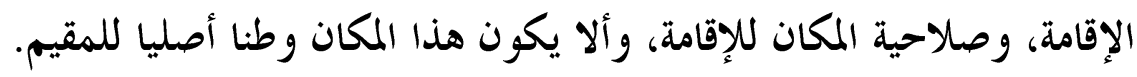
أما وطن السكنى فيشترط فيه شرطان وهما عدم نية الإقامة فيه، وعدم الإقامة فيه فعلا المدة القاطعة للسفر، وألا يكون وطنا فئن أصليا للمقيم (iv). ثانيا: نو اقض الوطن

كما أن لكل قسم من الأقسام السابقة للوطن شروطا يجب أن تتوفر في كــل

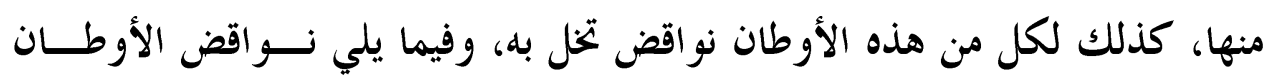
الثلاثة: 


\section{الوطن الأصلي - مأي}

ينتقض الوطن الأصلي بالانتقال منه إلى مثله بشرط نقل الأهل منــهـ وتـــــك

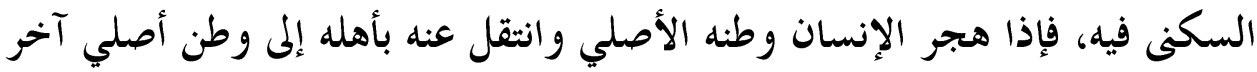
بشروطه لم يبق المكان الأول وطنا أصليا له، هذا عند الأحناف. ويرى الحنابلة أن الوطن الأصلي لا ينتقض باتخاذ وطن أصلي آخر.

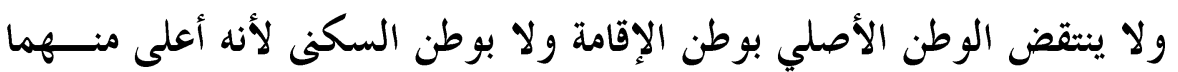

$$
\text { فلا ينتقض بو احد منها. }
$$

ينتقض وطن الإقامة بالوطن الأصلي لأنه فوقه، وينتقض بوطن الإقامة أيضــــا

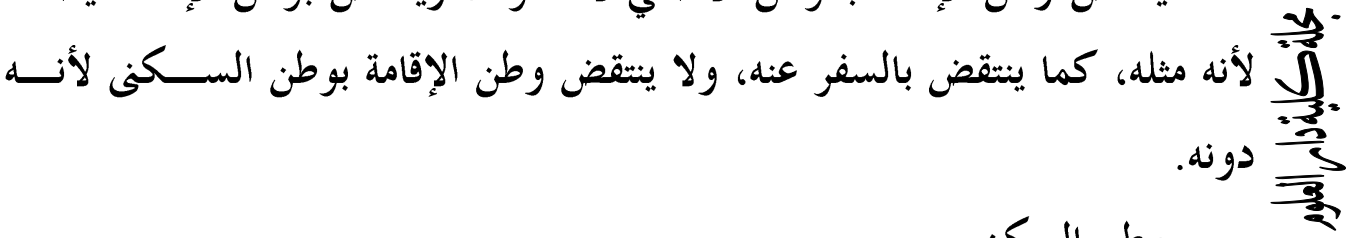

$$
\text { وطن السكنى }
$$$$
r \leq 7
$$

أما وطن السكنى فإنه ينتقض بالوطن الأصلي، وينتقض بوطن الإقامة وبـــوطن

$$
\text { مَ }
$$

أما الأولان فلأفما فوقه وأما الآخر فلأنه مثله. والثيء ينتقض بمثله أو بما هو

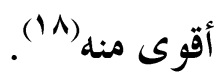

من استعر اض ما سبق من كلام الفقهاء يتبين أن للوطن حقوقا على الإنســان، وإلا لما جعل هذا الوطن أقساما عدة، ولما كان لكل قسم منها شروطا ونواقض، ولما كان أعلى هذه الأوطان الثلاثة أولى بما بعده منها، وفي الصفحات المقبلة يكشف لنا النظر في كتاب الله تعالم عن هذا. 


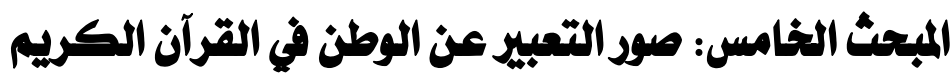

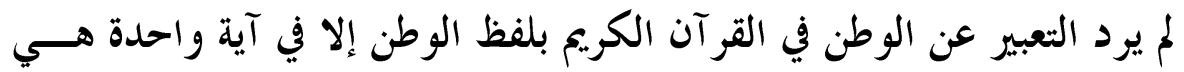

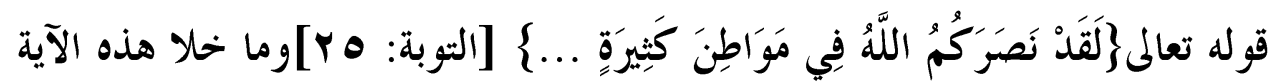
جاء التعبير عن الوطن بثلاثة ألفاظ هي لفظ الدار، ولفظ السكن، ولفظ البيت.

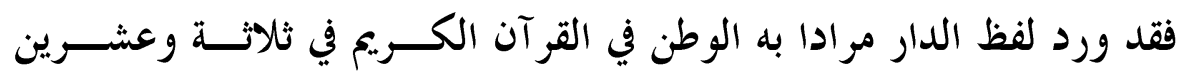

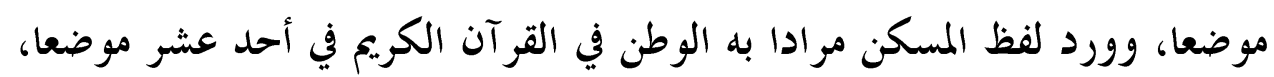

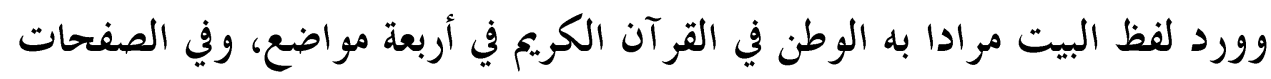

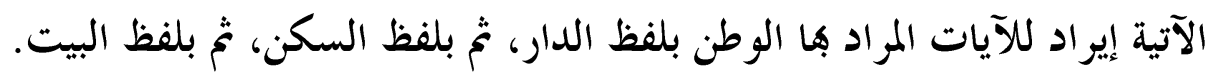

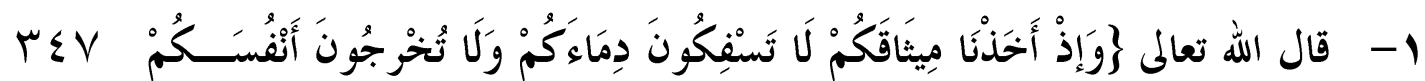

⿳亠口了口𧘇

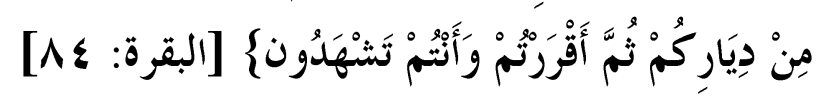

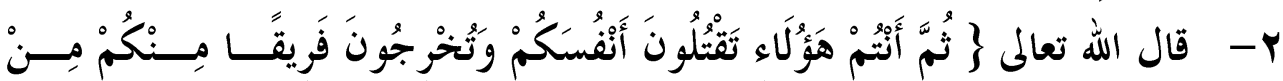

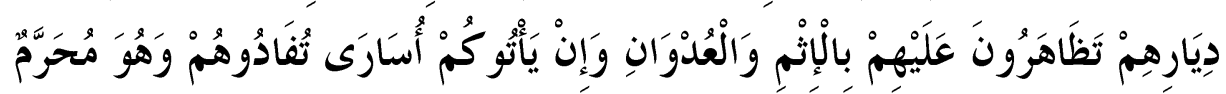

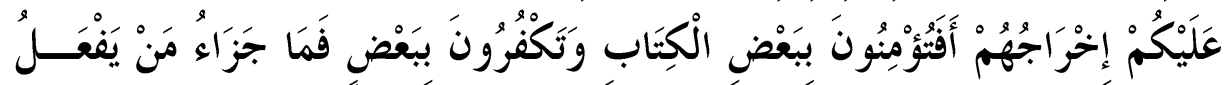

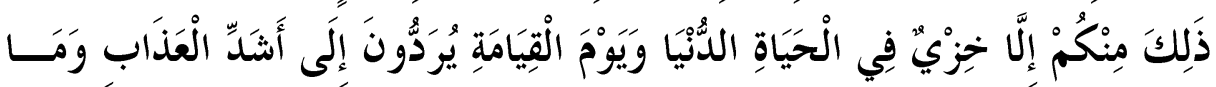

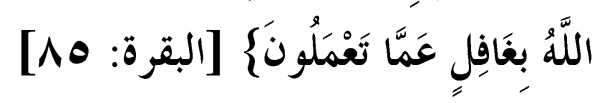

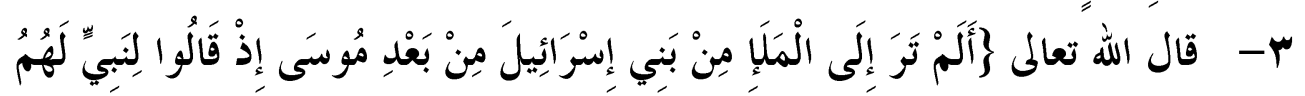

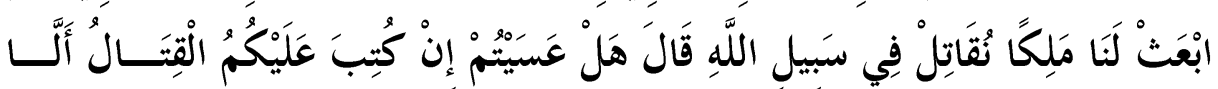

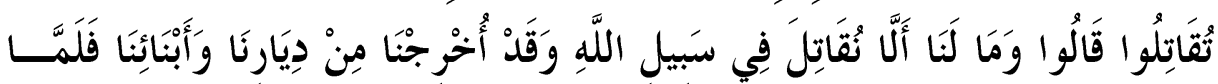

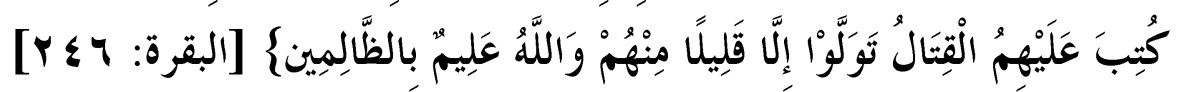




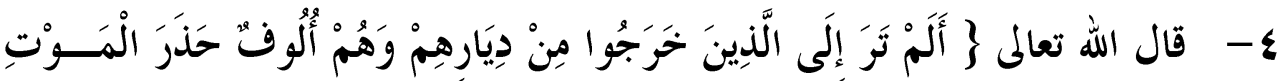

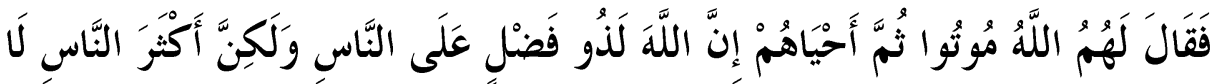

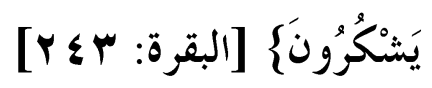

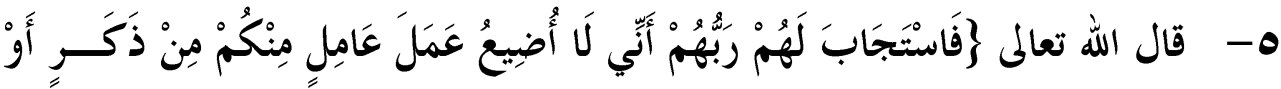

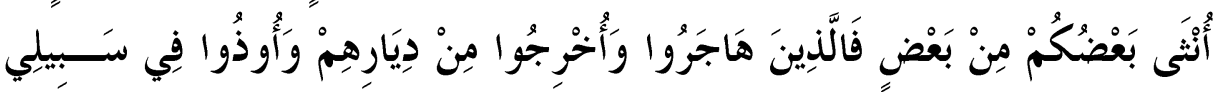

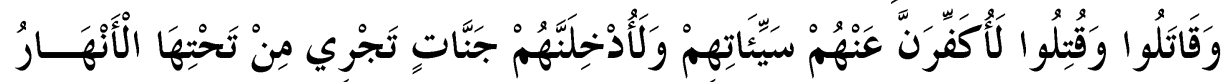

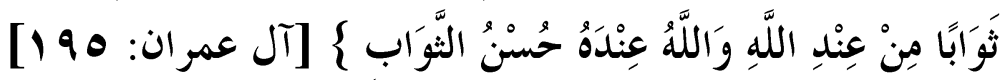

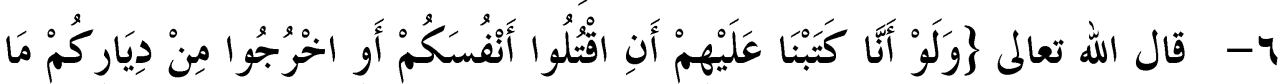

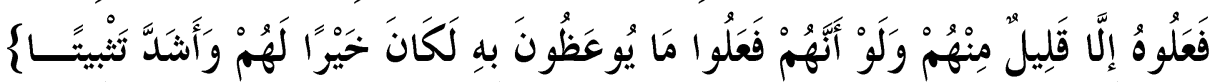

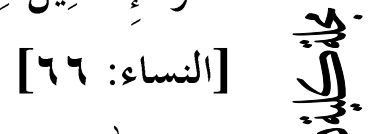

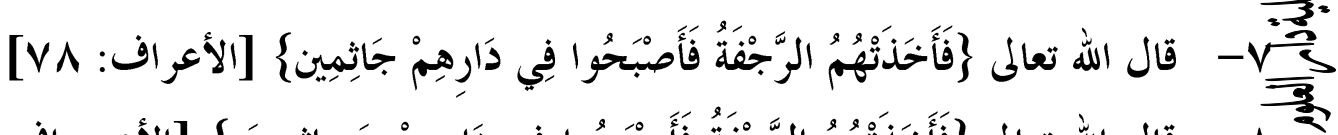
人

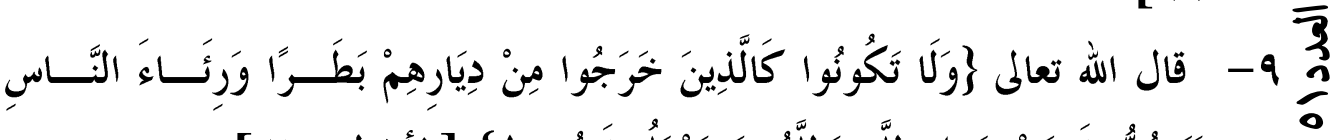

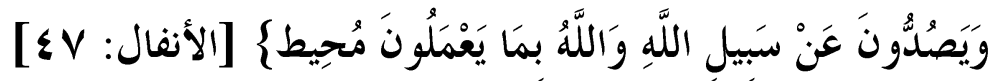

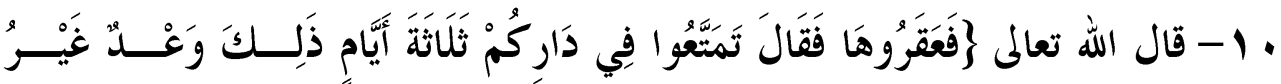

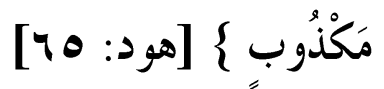

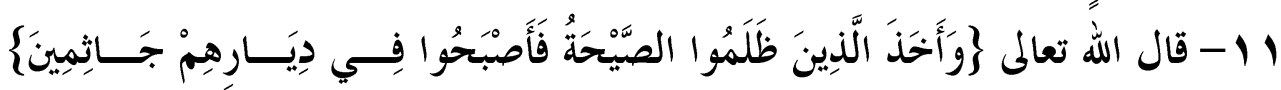

$$
\text { [ }
$$

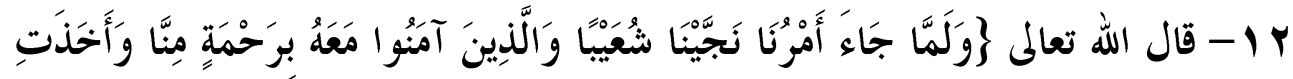

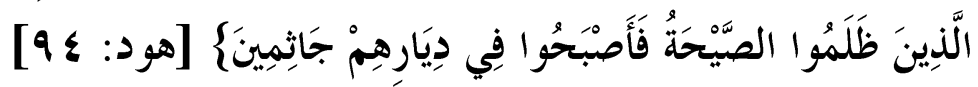

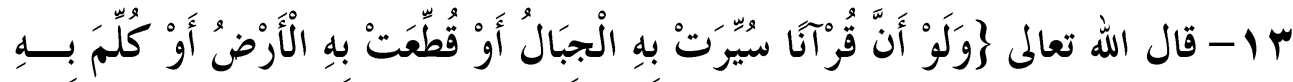

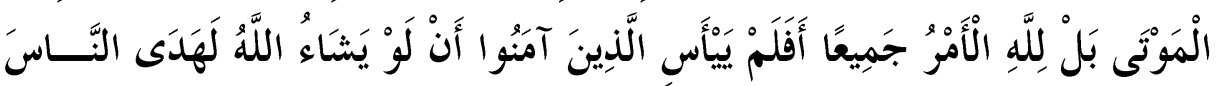




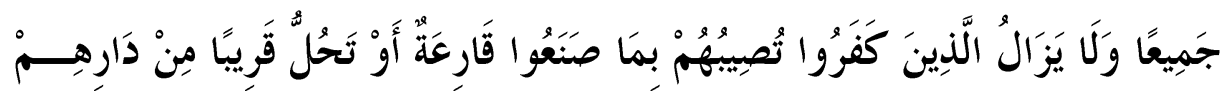

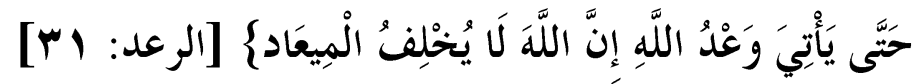

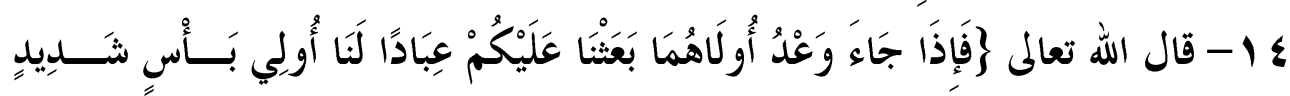

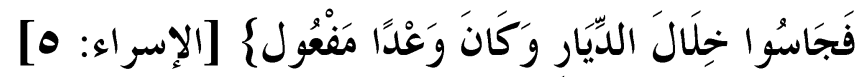

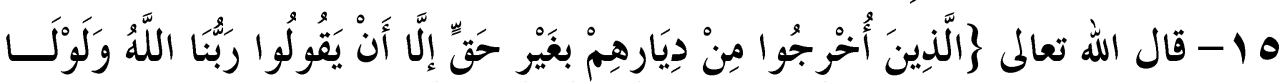

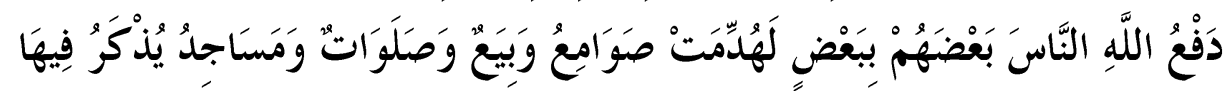

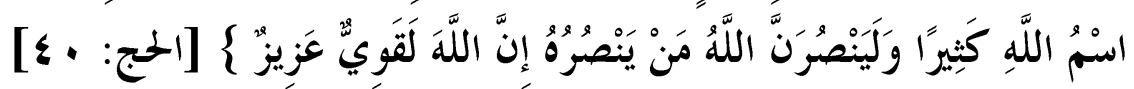

14 学. اللَّهِ وَمَا كَانَ مِنَ الْمُنْنَصِرينَ

دَارِهِه: جَساثِمِين $r \leq q$

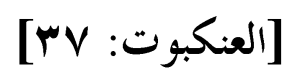

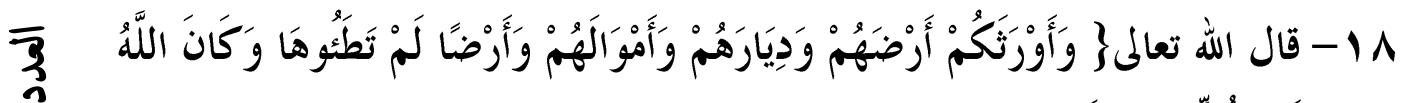

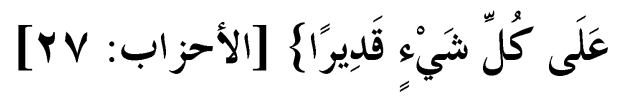
9 ا 19

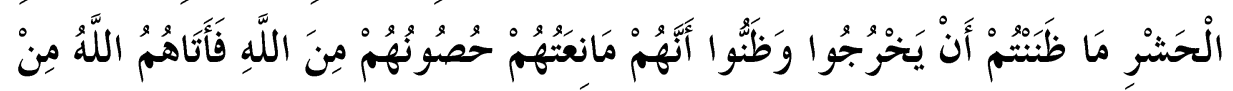

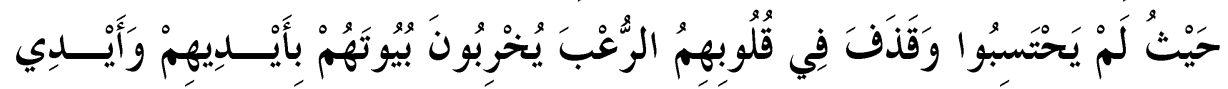

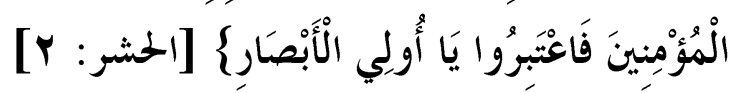

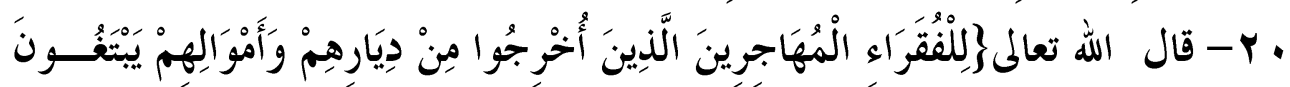

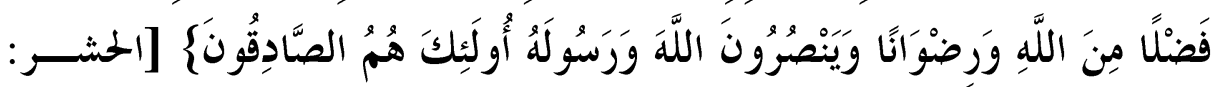

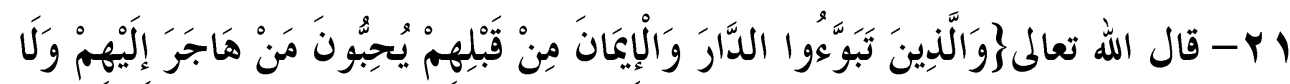

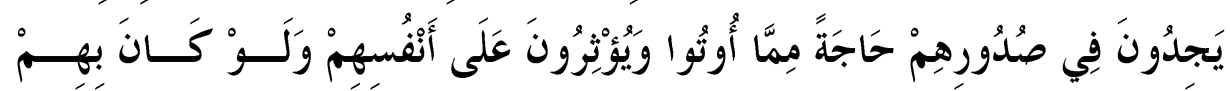

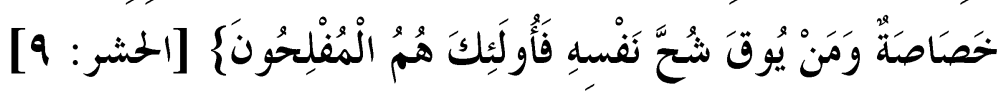




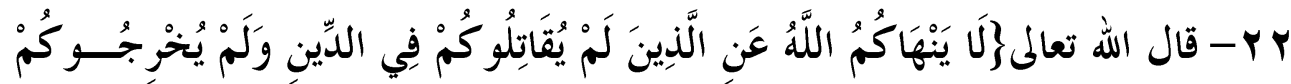

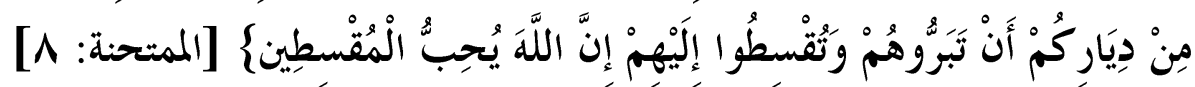

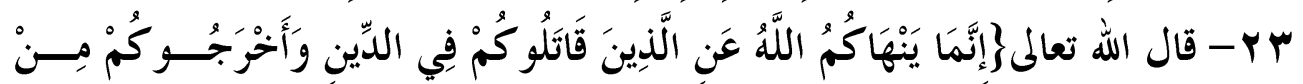

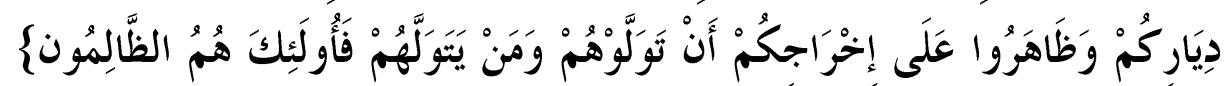

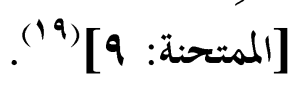

ثانيا: لفظ المسكن

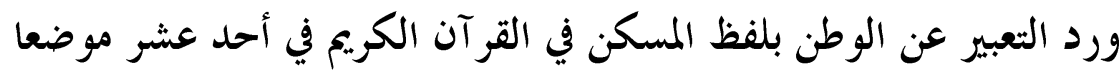

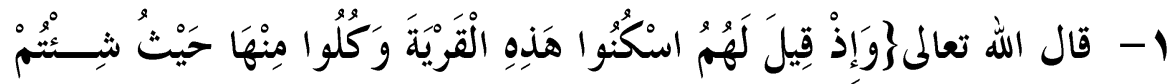

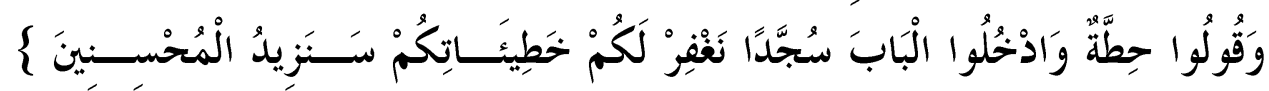

$$
\text { [إل }
$$

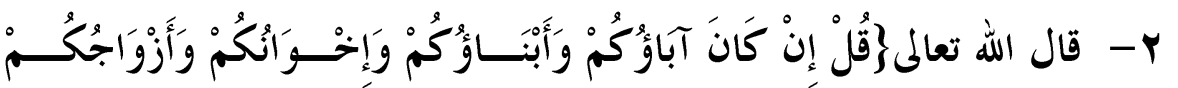

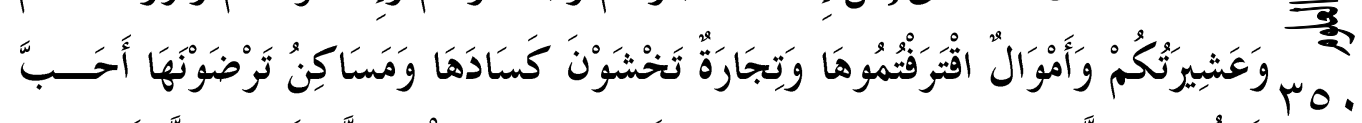

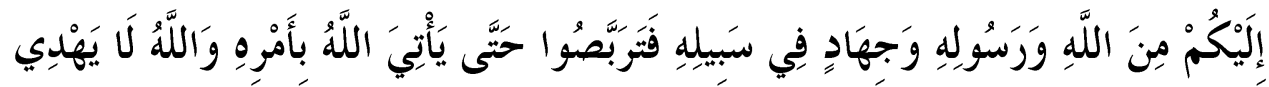

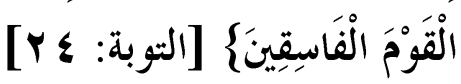

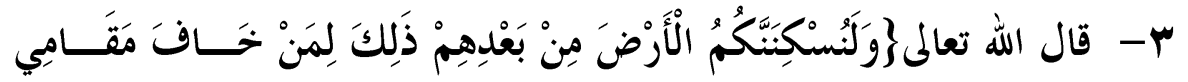

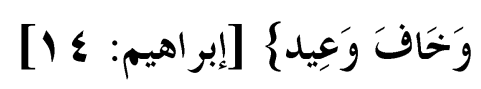

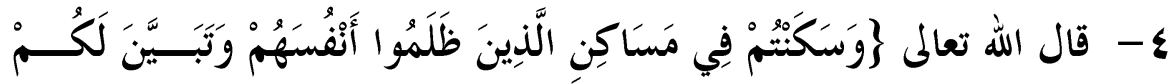

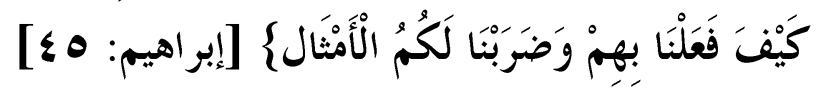

ه- قال الله تعالِى

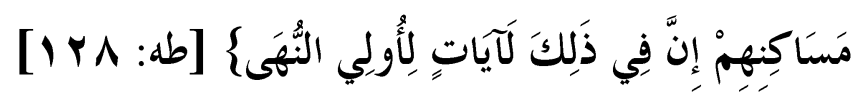

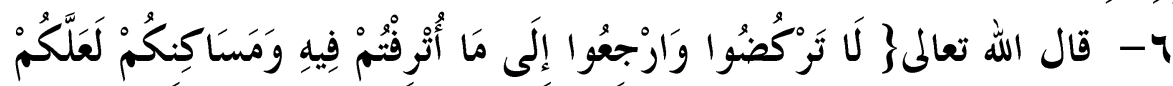

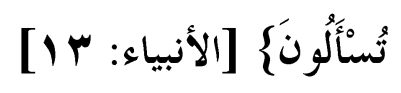




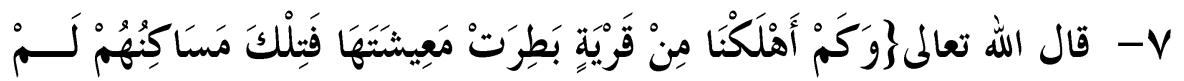

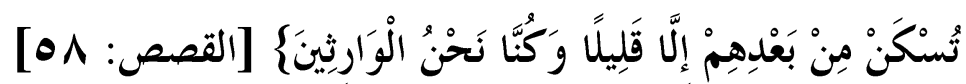

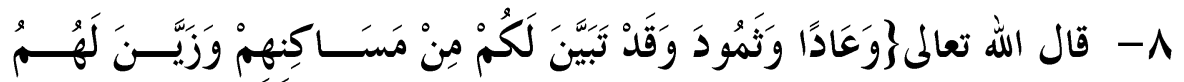

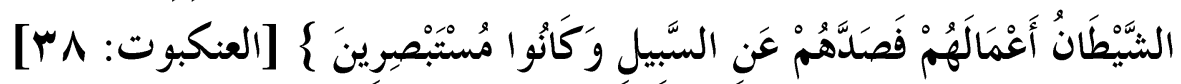

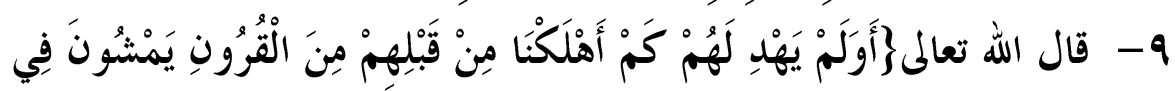

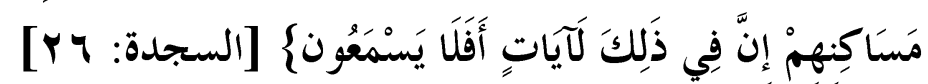

•

年

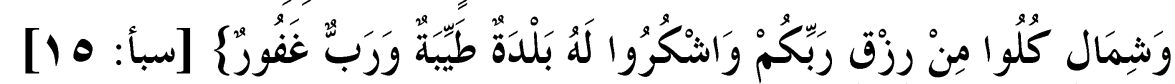

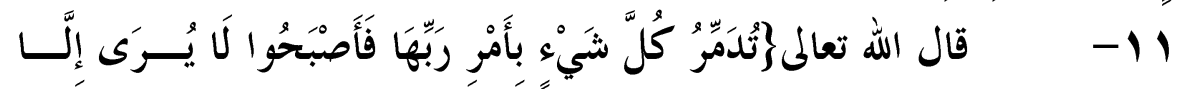

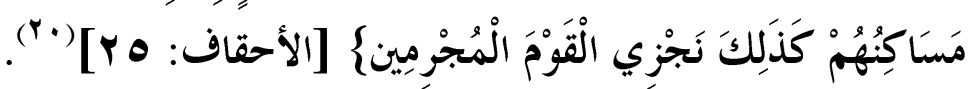

rol

ثالثا: لفظ البيت

$\frac{\overline{3}}{3}$

ورد التعبير عن الوطن بلفظ البيت في القر آن الكريم في أربعة مواضع:

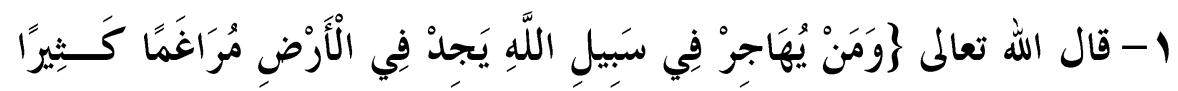

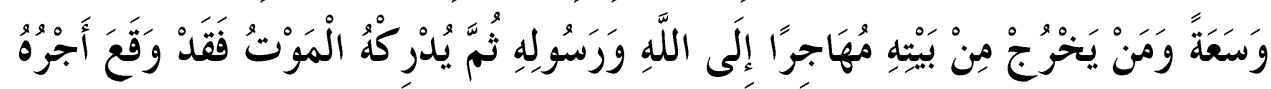

عَلَى اللَّهِ وَكَانَ اللَّهُ غَفْورًا رَحِيمًا

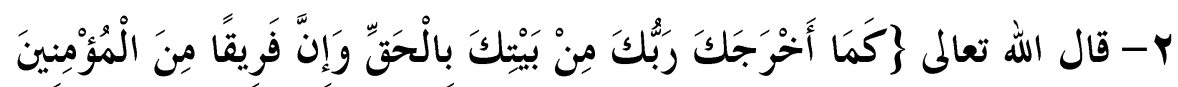

$$
\text { لَكَارِهُونِ }
$$

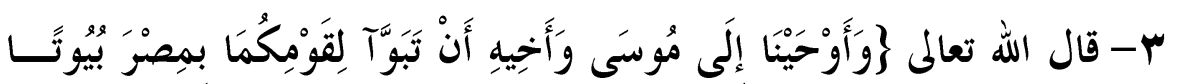

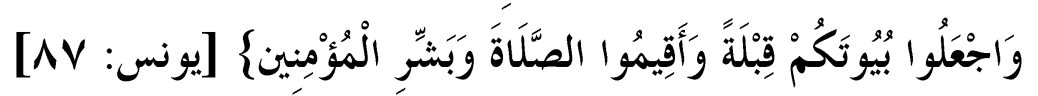

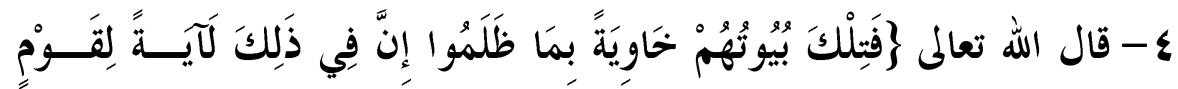




$$
\text { المبحث السادس: مأثورات في حب الوطن }
$$

الذي يستعرض تاريخ البشرية في أقو الها واعتقاداتحا يجد أن الله تعالم أودع فيها

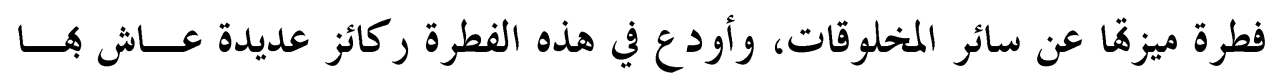
الإنسان في هذه الحياة، ومن هذه الر كائز حب الوطن. فحب الوطن فطرة فطر الله تعالم الحلتى عليها ظهرت في الإنسان لتميزه بالعقل

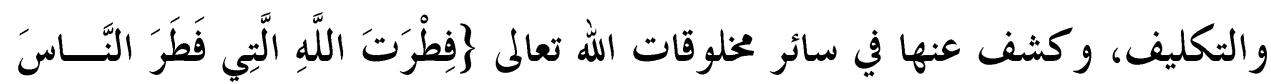

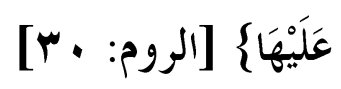

فلا تجد في بني البشر إلا وهو مفطور على حب وطنه، لا يخــرج عــن هــــه الفطرة إلا شاذ، وكم ظهر على مر الدهر وكر العصر في كتابات العلماء وما أثــــ

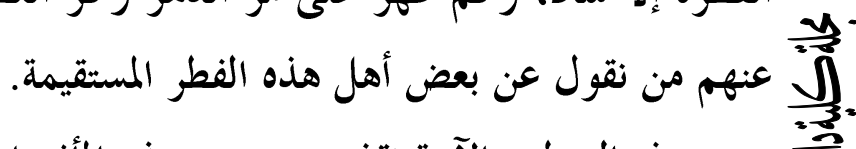

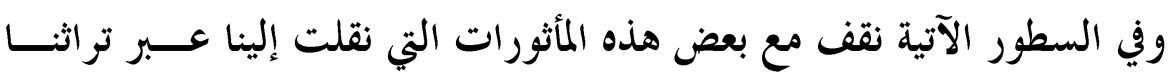
r حهم وتصلح للتقدمة بين هذه الدراسة التي نحن بصددها.

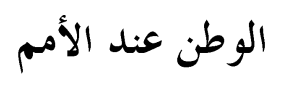

هذا بعض ما أثر في حب الوطن عن بعض الأمم:

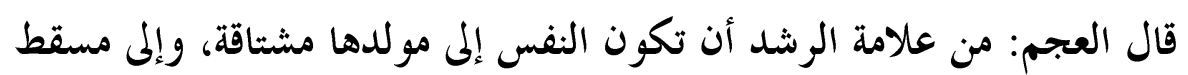
رأسها تو اقة.

وقال الهند: حرمة بلدك عليك مثل حرمة أبويك لأن غذاءك منهما وغــــاؤهما

$$
\text { وقالت العرب: حاك أحىى لك وأهلك أحفى بك. }
$$

و كانت العرب إذا غزت وسافرت حملت معها من تربة بلدها رمــلا وعفـــرا تستنشقه عند نزلة أو زكام أو صداع، ومن هذا أخذ الطائي قوله: كم متزل في الأرض يألفه الفتى ...وحنينه دوما لأول منزل 
وقيل لبعض الأعراب: ما الغبطة؟ قال الكفاية مع لزوم الأوطان والجلوس إلى

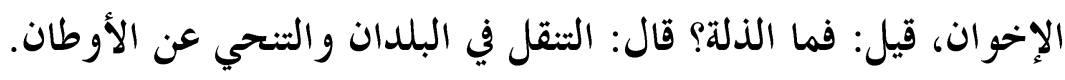

$$
\text { الوطن عند الحكماء }
$$

وهذا بعض ما أثر في حب الوطن عن الحكماء:

قالت الفلاسفة: فطرة الرجل معجونة بحب وبل وطنه

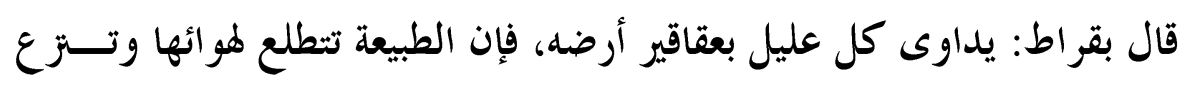

إلى غذائها .

忽

وقال أفلاطون: غذاء الطبيعة من أنجع أدويتها .

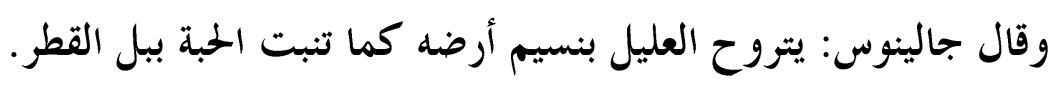

وشبهت الحكماء الغريب باليتيم اللطيم الذي ثكل أبويه فلا أم ترأمه ولا أب الب البه

ror

يحنو عليه.

$\overline{3}$

$$
\text { ما أثر عن أناس في حب الوطن }
$$

قال أحدهم: الكريم يحن إلى جنابه، كما يحن الأسد إلى غابه.

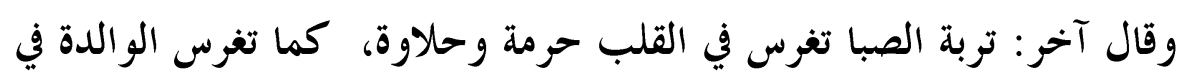

القلب رقة وحفاوة.

وقال آخر: إذا كان الطائر يحن إلى أوكاره، فالإنسان أحق بالحنين إلى أوطانه.

$$
\text { وقال آخر: ميلك إلى مولدك من كريم محتدك. }
$$

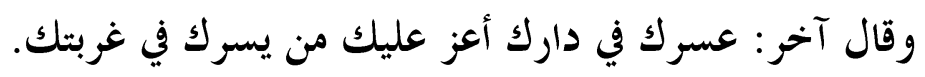

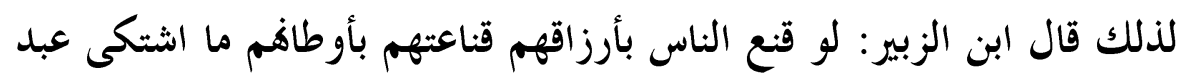
الرزق.

وقال آخر: يحن اللبيب إلى وطنه كما يحن النجيب إلى عطنه.

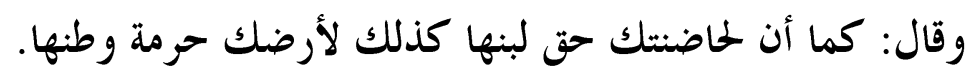


وهؤلاء الملوك و الجبابرة الذين لم يفتقدوا في اغترابهم نعمسـة، ولا غـــادروا في

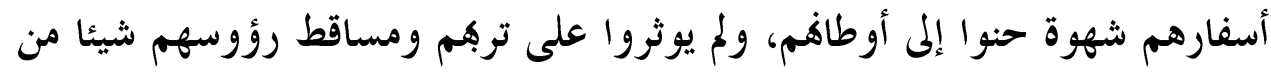

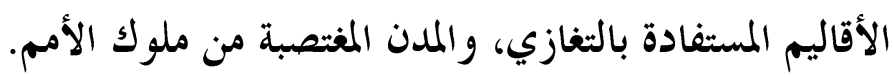

وهؤلاء الأعراب مع فاقتهم وشدة فقرهم يحنون إلى أوطافم ويقنعون بتــــهم

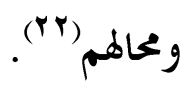

$$
\text { وقيل :لولا حب الوطن لخرب بلد السوء. }
$$

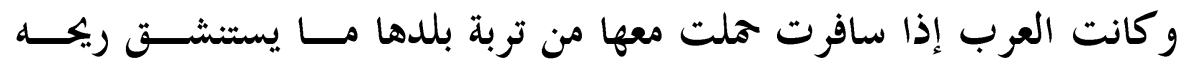

$$
\text { وتطرحه في الماء إذا شربته من كثرة حبها لأوطانها. }
$$

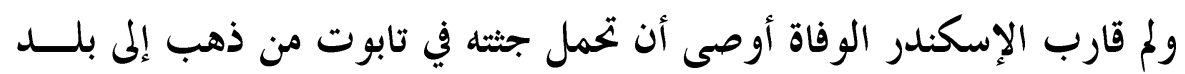

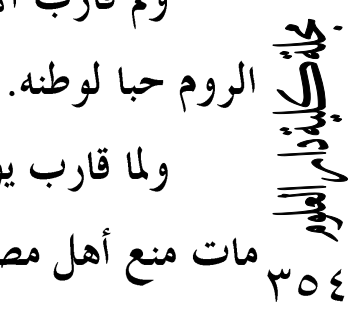

نقله موسى عليه السلام إلى تربة آبائه (Trا). 


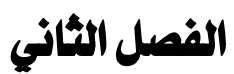 الوطن بين هدي القرآن وضلالات الأفهام}

哥.

roo

⿳亠口了口𧘇

$$
\begin{aligned}
& \text { وفيه تسعة مباحث: } \\
& \text { المبحث الثاني: الوطن حق للإنسان } \\
& \text { المبحث الثالث: الوطن نعمة من نعم الله تعالى } \\
& \text { المبحث الرابع: الموازنة بين الدين والوطن } \\
& \text { المبحث الخامس: الحرمان من الوطن عقوبة لمرن } \\
& \text { المبحث السادس: الإخراج من الوطن قرين القتل والعذاب } \\
& \text { المبحث السابع: هجرة الوطن بين الثواب والعقاب } \\
& \text { المبحث الثامن: مشروعية الدفاع عن الوطن } \\
& \text { المبحث التاسع: موقف الأنبياء من الوطن } \\
& \text { المبحث الأول: تباين الأفهام في معنى الوطن }
\end{aligned}
$$

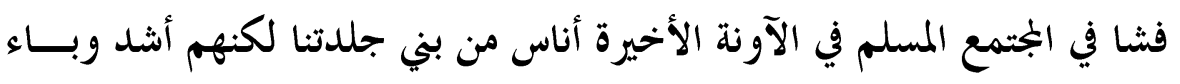
من الأعداء على ديننا وعقيدتنا ووطننا، بحسن نية تارة و بسوء نية تارة أخرى، فهم كالسوس الذي يتخلل العظام داخل الجمسد الواحد، أو قل كالســــــان الــــي إذا ابتلي به الجحسم صعب على الأطباء استئصاله، إلا من أعطي الحكمة وتذرع بالصــبر وتفنن في العلم، هؤلاء رأوا الباطل حقا ورأوا الحتى باطلا، واختلط عليهم الأمر فدار بأدمغتهم كما تلدور الخمر بدماغ صاحبها. وانقسم هؤلاء الناس إلى فرقتين متباينتين كلاهما باين الحقى وعادى الصـــواب، أولى هاتين الفرقتين رأت أن الوطن لا يعدو أن يكون حفنة تراب، أو صنما يعبد من

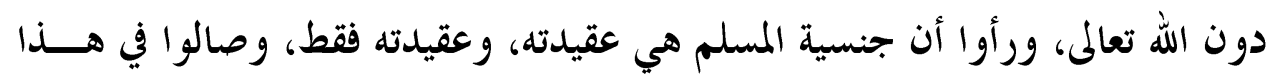
الأمر وجالوا وشرقوا وغربوا، وتكلموا بما يكاد يذهب لب العاقل. 
وثانيتهما رأت أن الوطن هو الأصل والأساس وما وراءه تابع، فأعلـــت مـــن قدره ورفعت من قيمته إلى مكانة ليست له في الحقيقة، فرفعوه فوق العقيدة وفــــوق الدين، فهو عندهم الأصل والدين و العقيدة تابعان له. "و هما رؤيتان قاصرتان لدوائر الانتماء وأصول الهوية المصرية العربية الإسلامية على الرغم من تناقض منطلقات كل منهما، فالأولى رؤية دينية ترى الوطنيــة ولاء

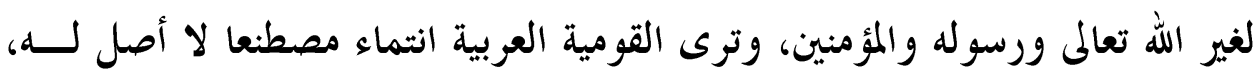
والأخوة الإنسانية مدعاة لتمييع التمايز العقدي والاختلالف الديني، وربما وقع هــــه الؤية طعنها البعيد ما جد من فكر علمالي يرمي إلى إعادة تأسيس الموية والانتمـــاء خارج دائرة المرجعية الحضارية الأصلية ومن قبلها الإسلام برؤيته وبمبادئه الجامعة. ولكن على وقع رد العقل الديني النافي لمعاني الوطنية والقومية والإنســانية في

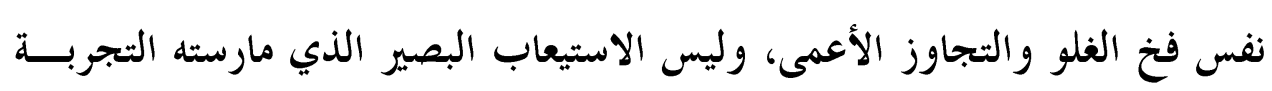

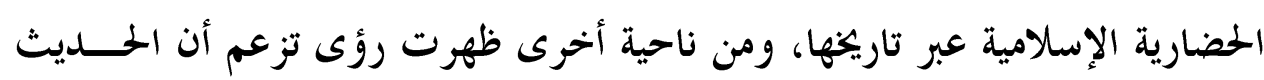
roy عن رابطة دينية في القرن العشرين سخافة أو كارثة أو تخلف، وأن العصر والمعاصرة لا يسمحان إلا بالر ابطة على أساس التراب والإقليم والقطر فكما أن انجلترا للإنجليز

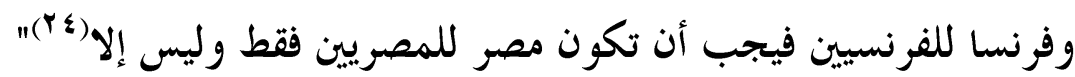
$\frac{3}{3}$ وفي السطور الأتية استعراض لبعض أقوال هؤلاء دون إفراط أو تفريط

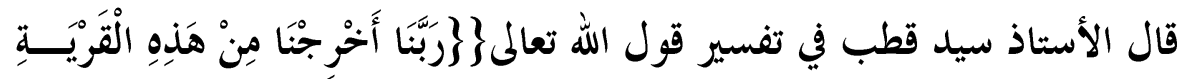

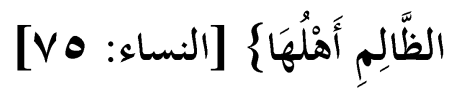
ولابد من لفتة هنا إلى التصور الإسلامي للبلد والأرض والوطن، إذ هذه القرية الظالم أهلها التي يعدها الإسلام - في موضعها ذاك - دار حرب يجــب أن يقاتــل

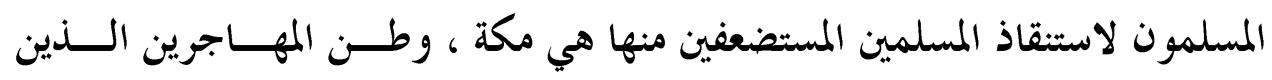
يدعون هذه الدعوة الحارة إلى قتال المشر كين فيها ويدعو المسلمون المستضعفون هذه الدعوة الحارة للخروج منها. 


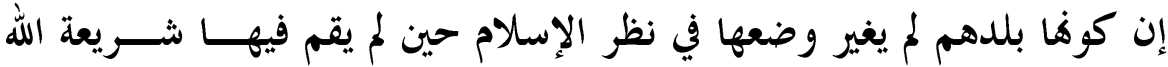
ومنهجه ،وحين فتن فيها المؤمنون عن دينهم وعذبوا في عقيدقم، بل اعتبرت بالنسبة

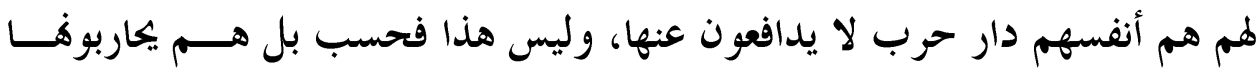
لإنقاذ إخوقم المسلمين منها. إن راية المسلم التي يحامي عنها هي عقيدته، ووطنه الذي يجاهد من أجله هــــ البلد الذي تقام شريعة الله فيه، وأرضه التي يدافع عنها هي دار الإسلام، التي تتخذ المنهج الإسلامي منهج حياة، وكل تصور آخر للوطن هو تصور غير إسلامي تنضح

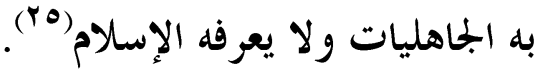
الزمان فيراها هنالك هنالك في السفوح، ويرى بين تلك القمة السامقة والســفوح

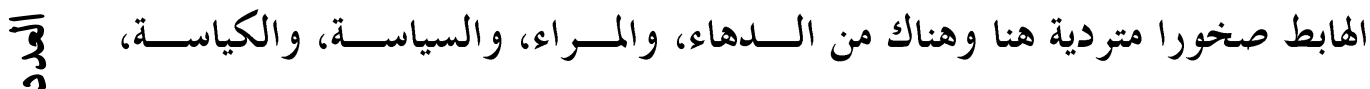

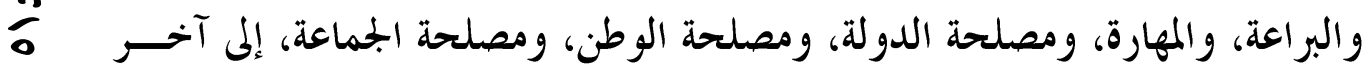

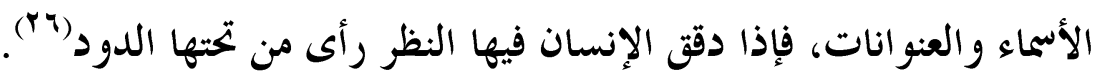
ويواصل الأستاذ سيد كلامه كواحد مُن يمثلون التيار الأول فيقول" إن الناس يقيمون لهم اليوم آلمة يسموفا القوم، ويسموفا الوطن، ويسموفا الشعب، إلى آخر ما يسمون، وهي لا تعدو أن تكون أصناما غير مجسدة كالأصنام السائدة التي كــان يقيمها الوثنيون، ولا تعدو أن تكون آلمة تشارك الله في خلقه، وينذر لهم الآبناء كما كانوا ينذرون للآلهة القديمة يقدمون لمم كالذبائح التي كانت تقدم في المعابد علــى

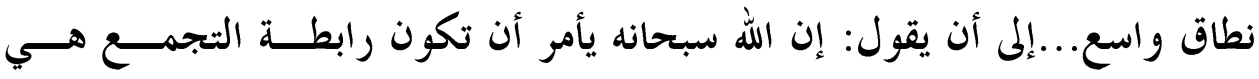
العقيدة، ولكن القومية أو الوطن يأمر باستبعاد العقيدة من قاعدة التجمع، أن يكون الجنس أو القوة هو القاعدة فمن هو الإله الذي نتبع أوامره أهو الله سبحانه أم هـي الآلمة المدعاة(YV) 
ثم يعلنها صريحة في كتابه معالم على الطريق فيقول: بهذه النصاعة الكاملة وبهذا الجزم القاطع جاء الإسلام جاء ليرفع الإنسان، ويخلصه من وشائج الأرض والطــين، ومن وشائج اللحم والدم، فلا وطن للمسلم إلا الذي تقام فيه شــــيعة الله، فتقـــــم الروابط بينه وبين سكانه على أساس الارتباط في الله، ولا جنسية للمسلم إلا عقيدته التي تجعله عضوا في الأمة الإسلامية في دار الإسلام، ولا قرابة للمسلم إلا التي تنبثق لهائ من العقيدة في الله فتصل الوشيجة بينه وبين أهله في الله، ليست قر ابة المســلم أبــاه

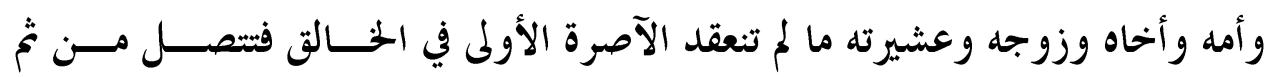

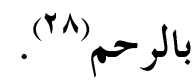

هكذا نري الأستاذ سيد قطب يلغي كل الصلات الو اقعة بين البشر ما دامـــت

وهو فهم مغلوط يخالف الهدي القرآين الذي أضاء في كثير من آيات الكتــاب

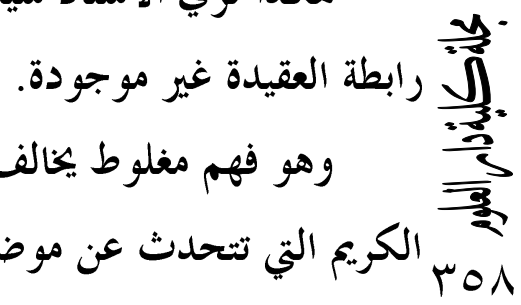

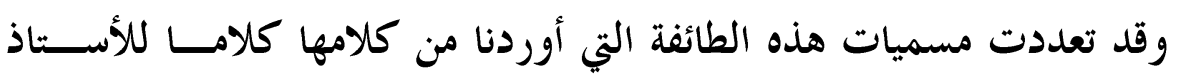
المرحوم سيد قطب، ولسنا في معرض تعديد الأسماء، فمنهج ديننا وعقيدتنا لا ينظــــ إلى القائل بقدر ما ينظر إلى القول، فنحن لا نحاكم القائل فقد أفضى إلى ربه تعــالى $\overline{3}$
$\frac{2}{0}$ وإنما نحاكم أفكارا وأقو الا ومذاهب ملتوية لبست على الناس عقيدقم واجتالتهم عن دينهم وهدي قر آكم وسنة نبيهم. هذه الفرقة وضعت الوطن عن مكانه ومكانته حتى إنه عندها لا يمثــل شـــئا

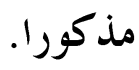
وطائفة أخرى رأت أن الوطن ألمى ما يمكن أن يدافع الإنسان عنه، ورفعتــه. على كل شيء حتي وصل الأمر أن تعلي هذه الطائفة من قدره فوق قـــدر الــدين والعقيدة، وأخذ هؤلاء ينظرون ويشرحون ويفسرون ويكتبون، وغفلوا عن أن هذا مجانب للصواب، وأن الفضيلة بين رذيلتين فلا إفراط ولا تفريط. 
ومن كلام هذه الطائفة نكتفي بنقل كلام الأستاذ زكي نجيب محمود في مقــال

كتبه قال فيه: - 20 - n

ما هي المعاني الكبرى التي يجيب بها المصري حين يسأل من أنت؟ فعنسـد هــــه

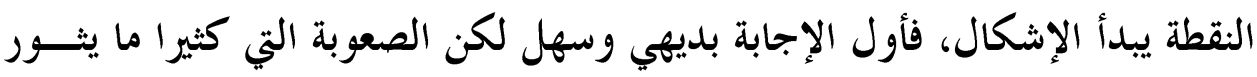

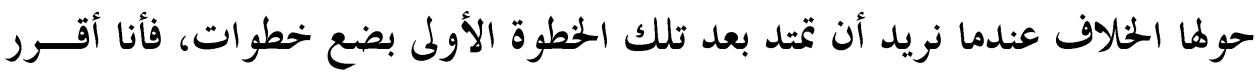

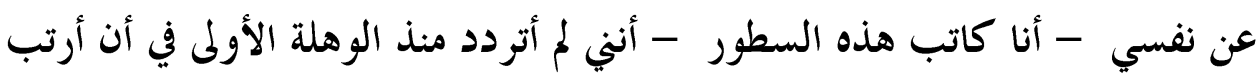

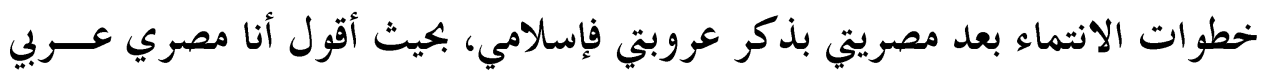

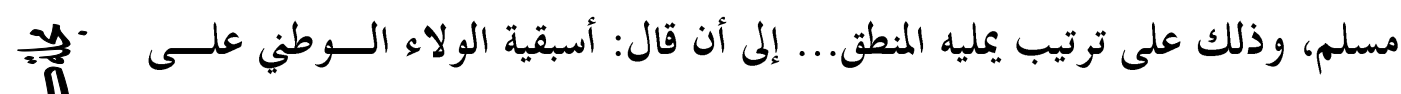

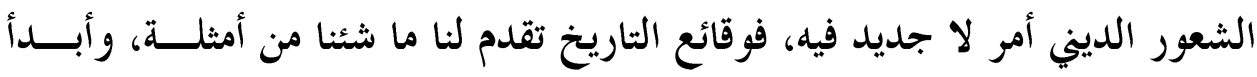

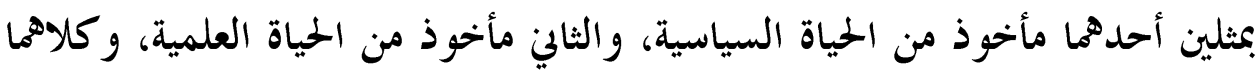

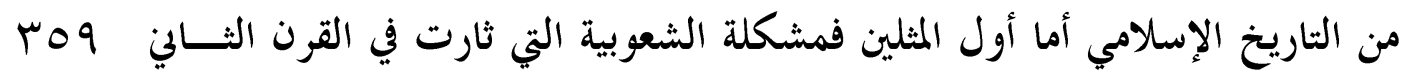

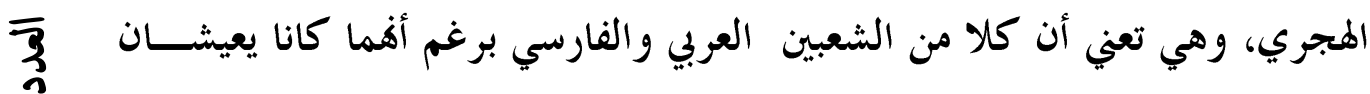

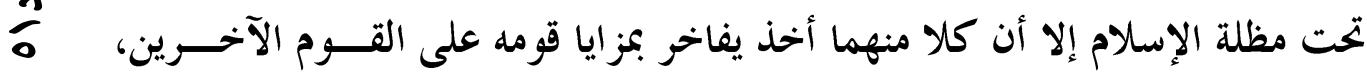

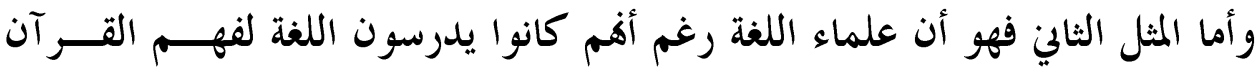

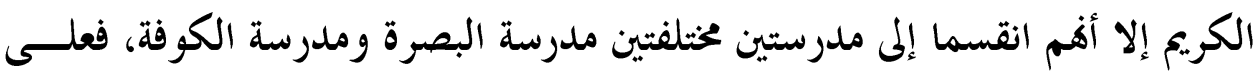

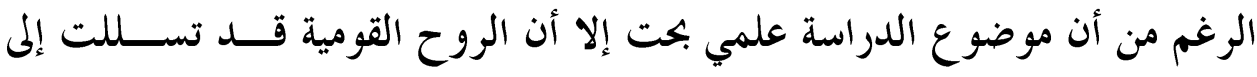

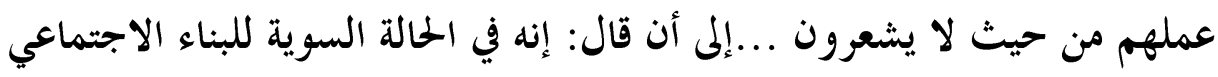

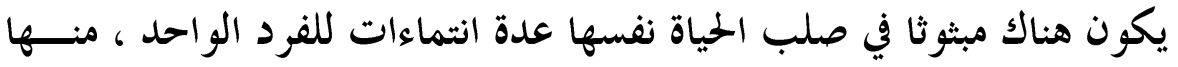

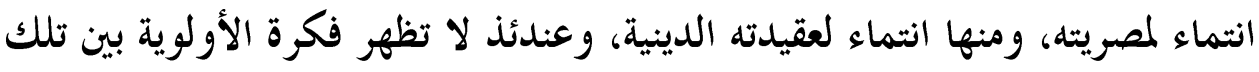

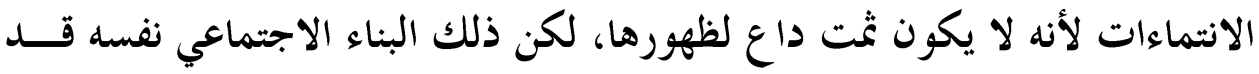

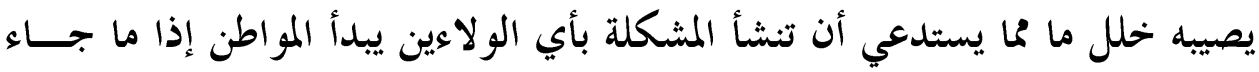

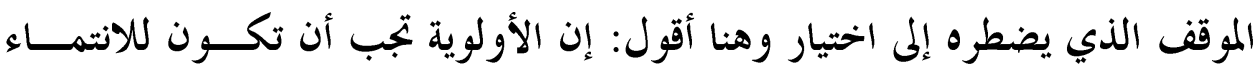


وعلى هذا المنحى درج كثير من الكتاب والباحثين من تقديم الوطن على الدين مقابلة للغلو الأول بغلو مثله، ولسنا في معرض السرد لأسمائهم وإنغا حسبنا أنا وقفنا على هذه الفكرة لنتولى الرد عليها من خلال استجلاء المعالي القر آنية التي تتحسـدث في هذا الثأن، وفي السطور الآتية وقفة مع هاتين الطائفتين إحداهما في إفراطهما، والثانيسـة في تفريطها، نستجلي الحقيقة من كتاب الله تعالم وسنة نبيه صلى الله عليه وســلم والله من وراء القصد وهو حسبنا ونعم الوكيل.

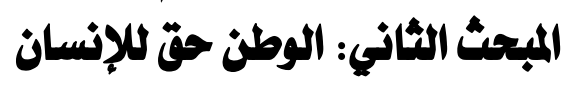

أصَّل الإسلام لمسألة حب الوطن والانتماء إليه والذود عنه و العمل على رفعته

.

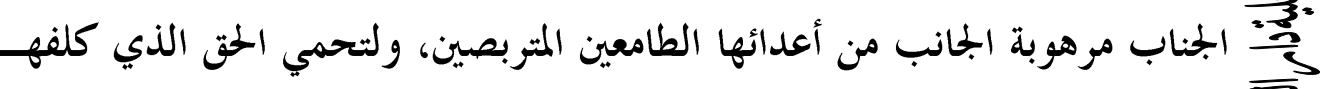
، ومن هذا التأصيل أن جعل الله تعالى الوطن حقا للإنسان يمتن عليــهـ ســـحانه ry. بالأمن والأمان فيه ويكثن على الدفاع عنه وبذل النفس والنفيس في سبيل رفعته فهو

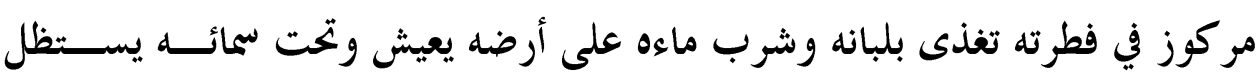
$\overline{3}$
3
0 عزته من عزته ورفعته من رفعته دونه لا تستقيم له حياة ولا يهنأ له عيش.

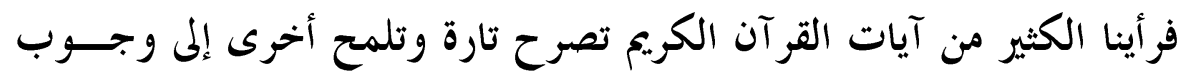
اتخاذ الإنسان وطنا يجيا فيه ومتبوأ يتبوأ ظلاله ومكانا يعبد الله تعالم فيه يأمن فيه على لى له

$$
\text { نفسه وماله وعر ضه ويستطيع فيه أن يقيم شعائره ويرضي فيه ربه. }
$$

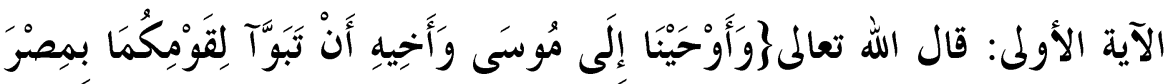

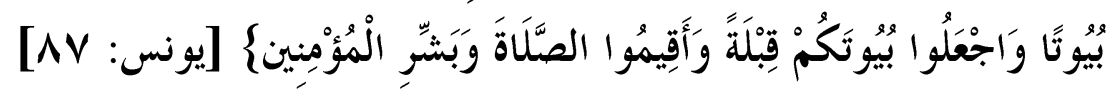


جعل الله تعالى في هذه الآية الكريمة اتخاذ الوطن وحيا أوحسـاه الله تعسلى إلى

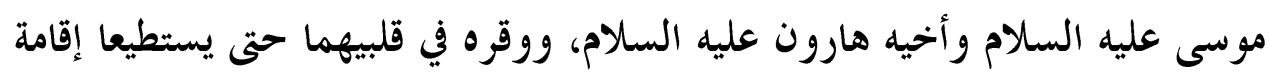

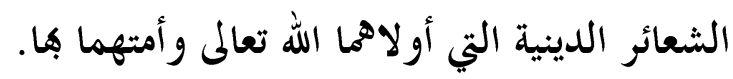

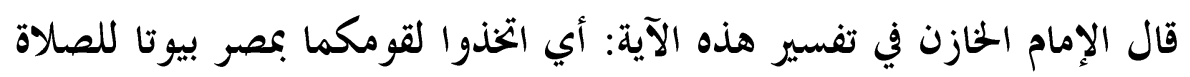

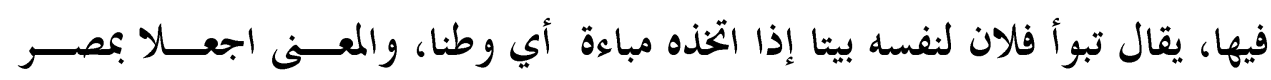
لقومكما بيوتا ترجعون إليها للصلاة والعبادة (•).

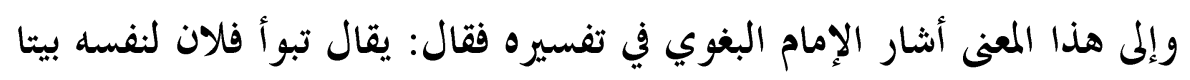

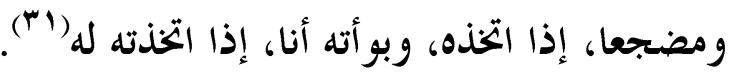

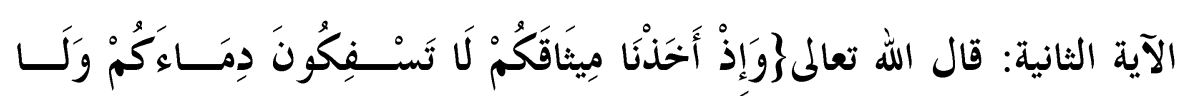

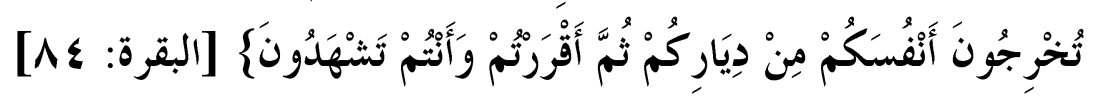

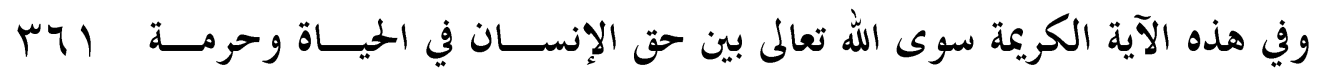

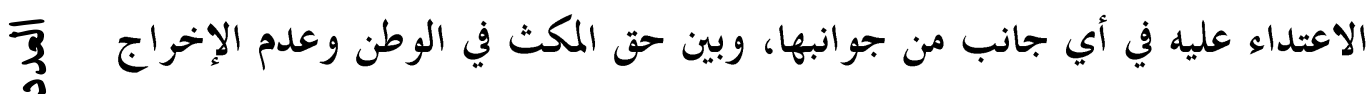
منه، ومن هنا أخذ الميثاق على بني إسرائيل.

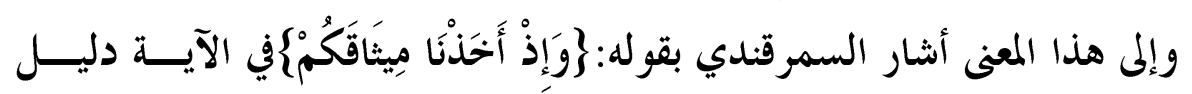

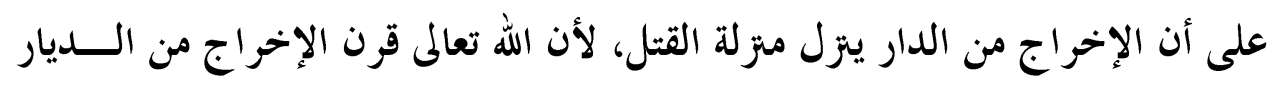

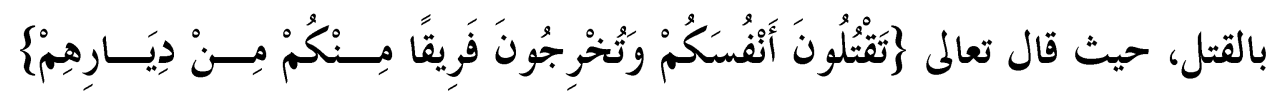

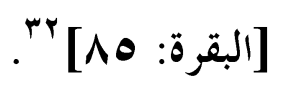

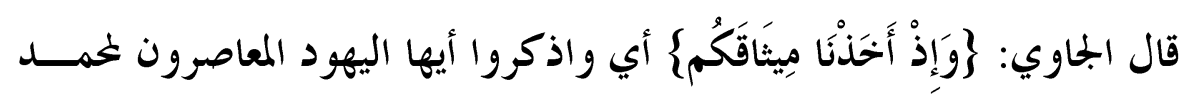

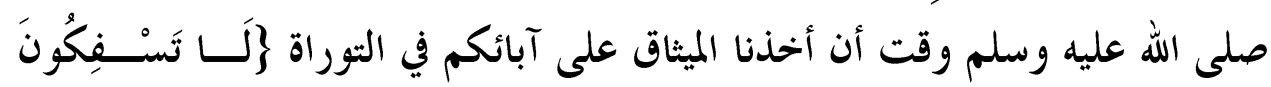

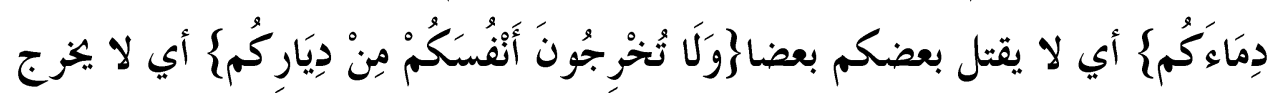

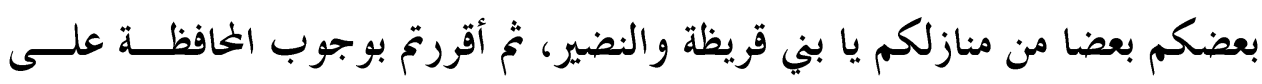

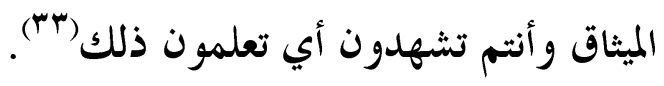




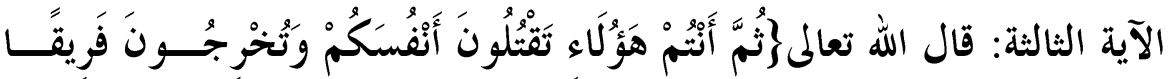

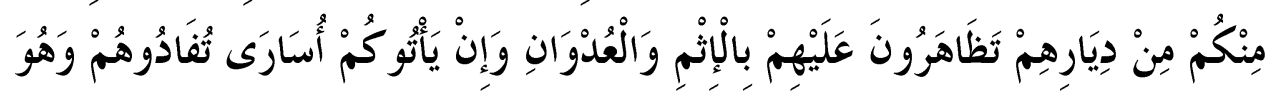

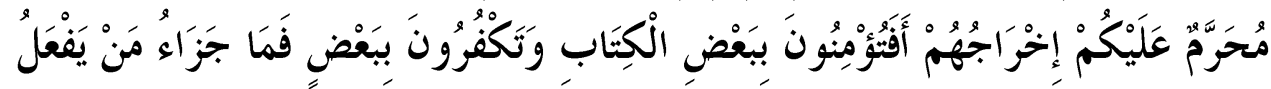

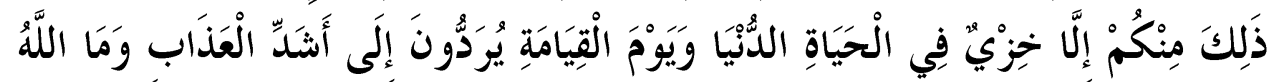

$$
\text { بغَافِلٍ عَمَّا تَعْمَلُوَنَ }
$$

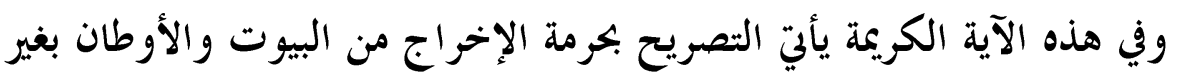

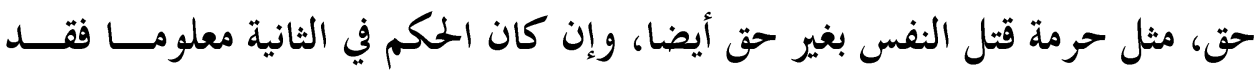
صرحت الآية بحرمته في الأولم بقوله تعالى

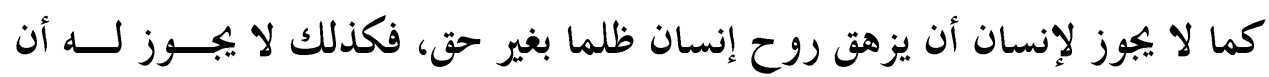

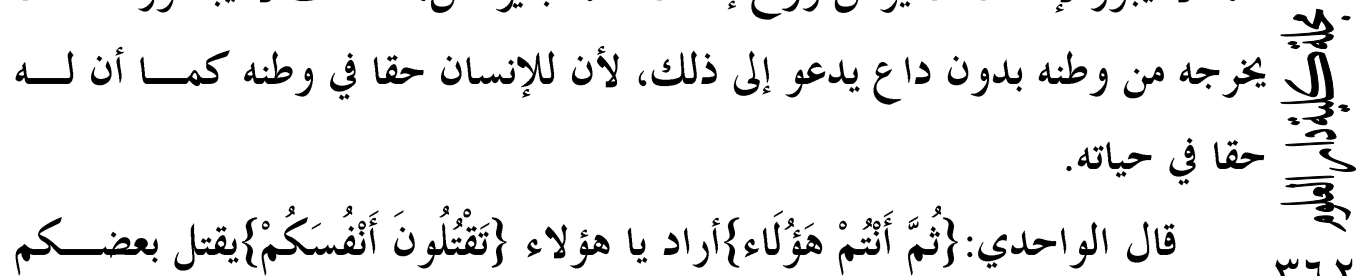

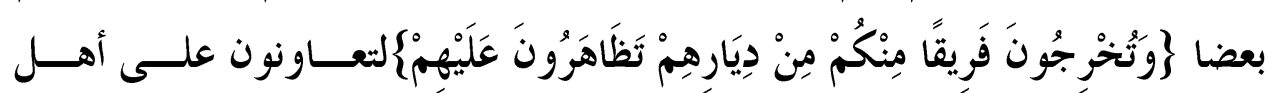

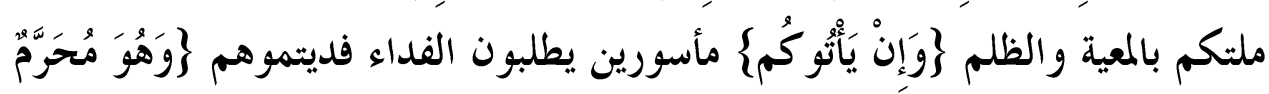

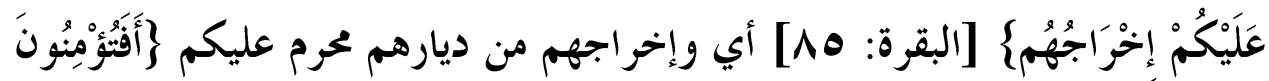
$\frac{\overline{3}}{3}$

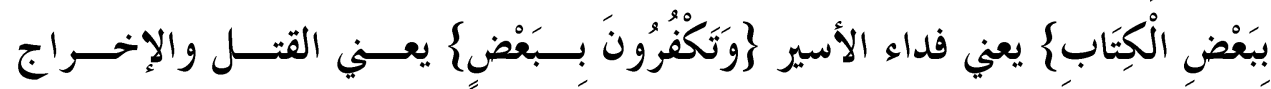

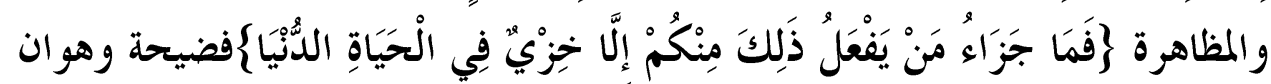
في الحياة الدنيا وقوله

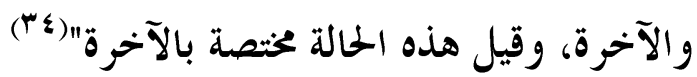

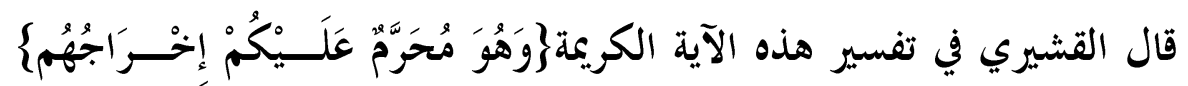

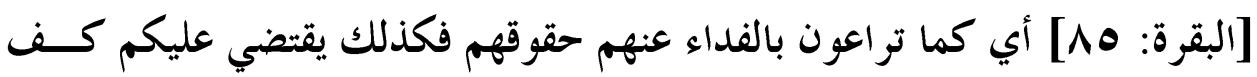

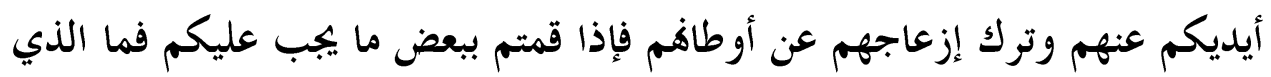


يقعدكم عن الباقي حتى تقوموا به كما أمرتم أما علمتم أن من فق بين ما أمر به فآمن

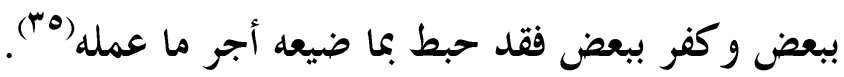

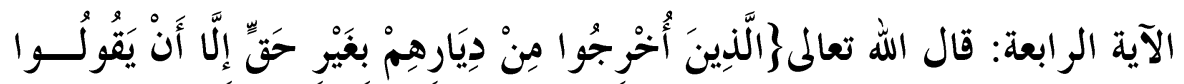

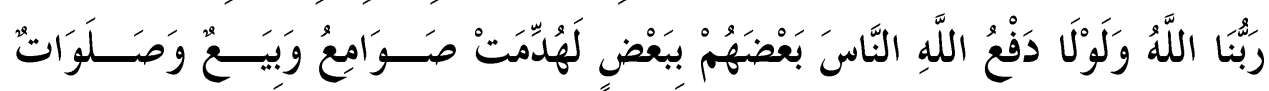

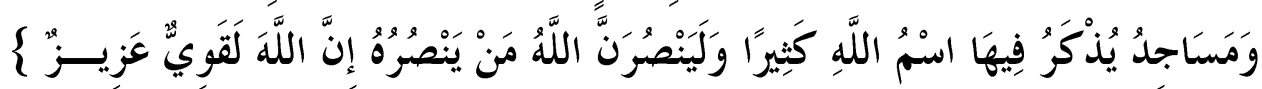

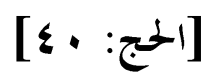

في هذه الآية إظهار لعلة جواز المقاثلة والقتال وتشريع الجههـاد في سـبيل الله الله

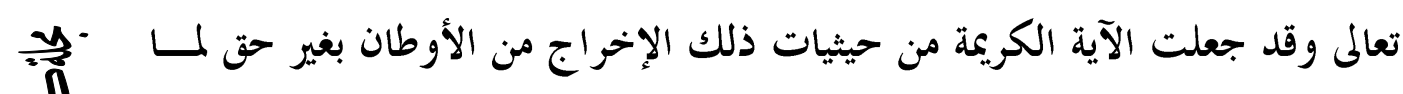
年

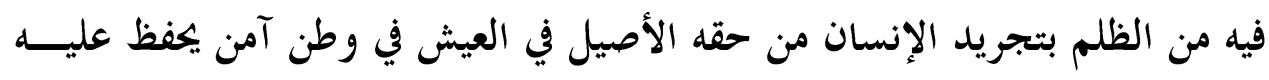

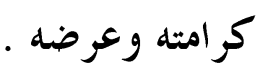

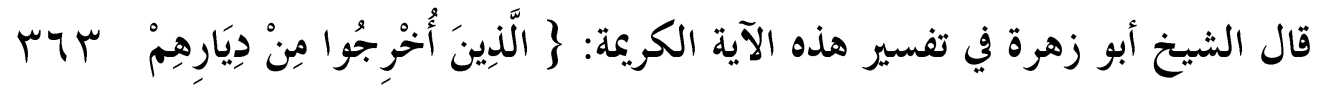

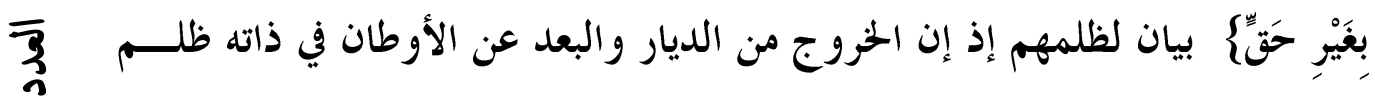

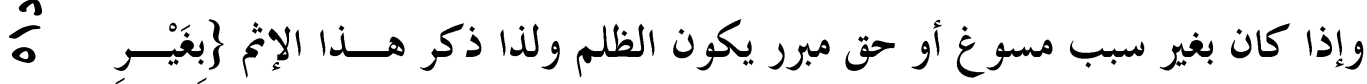

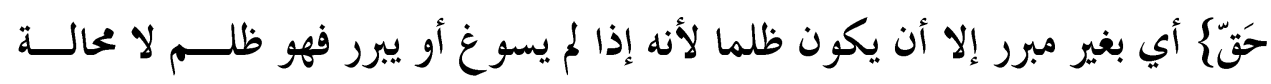

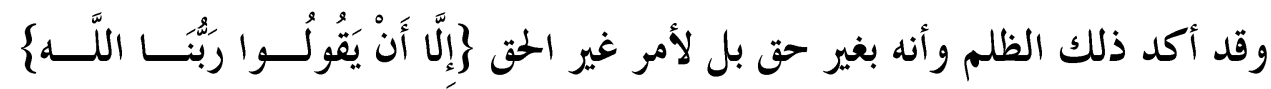

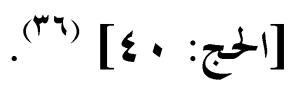

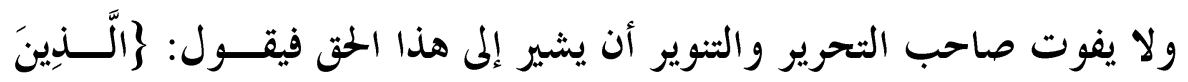

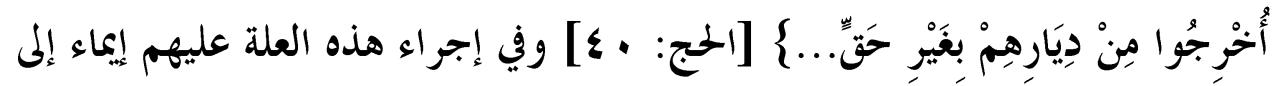

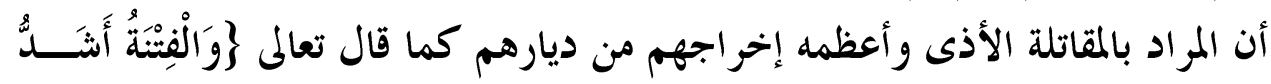

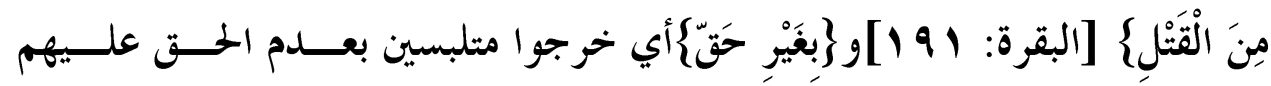

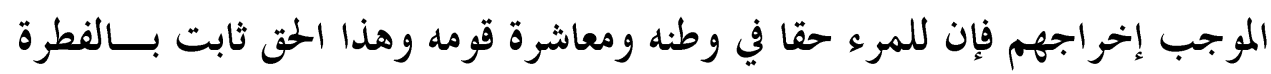

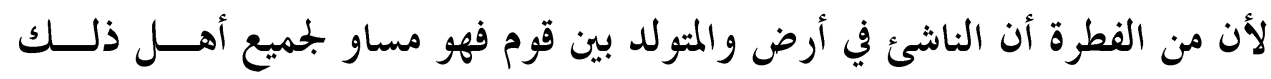

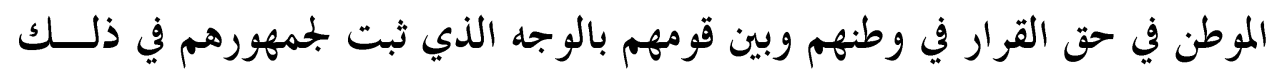


المكان متقادمة أو قهر غلبة لسكانه كما قال عمر بن الخطاب رضي الله عنــهـ "إفــــا بلادهم قاتلوا عليها في الجحاهلية وأسلموا عليها في الإسلام" ولا يزول ذلك الحق إلا بموجب قرره الشرع أو العوائد قبل الشرع كما قال زهير فإن الحقى مقطعه ثلاث...يمين أو نفار أو جلاء

فمن ذلك في الثرائع التغريب والنفي ومن ذلك في قوانين أهل الجاهلية الجلاء والخلع وإنما يكون ذلك لاعتداء يعتد به المرء قومه لا يجدون له مسلكا من الــردع غير ذلك(rv). وبعد هذا النطواف في كلام المفسرين حول الآيات الكريمة السابقة وبيــان أن للإنسان حقا في وطنه تبقى لحة مهمة نستطيع أن نقرأها من كل الآيات الـــواردة في

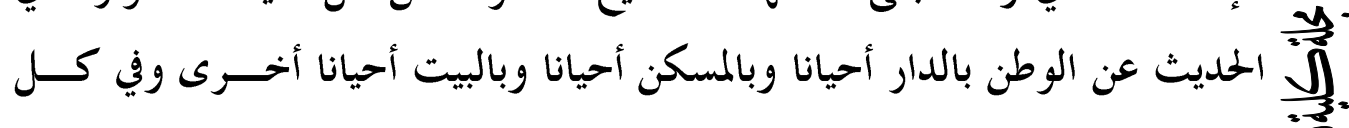

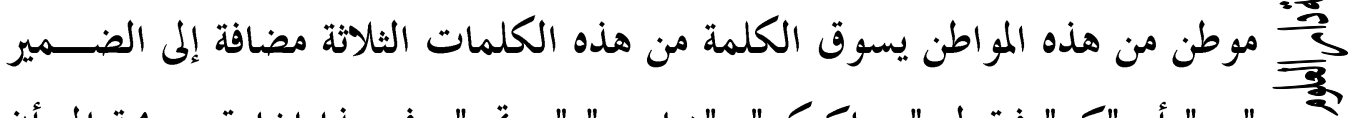
ع حَب "هم" أو "كم" فيقول "مساكنكم" "ديارهم" "بيوقم" وفي هذا إثارة صريحة إلى أن الإضافة هنا تفيد معنى اللام أي ديار وبيوت ومساكن هي لفم وسواء كانت الــلام للملك أو للاستحقاق أو للاختصاص ففيها ثلاثتها أن الوطن حق للإنسان والله تعالى

وقد سبق سرد تفصيلي للآيات الكريمة في هذا الشأن في البحث الخامس مــن

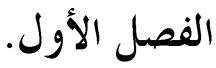

\section{المبحث الثهالث: الوطن نعمة من نعم الله تعالى الألى}

من أعظم نعم الله تعالمى على الإنسان استقراره في بلده آمنا على نفسه وأهله عابدا ربه سبحانه مطيعا لحالقه وقد جسد النبي هذا المعنى عندما اختصر الــدنيا في

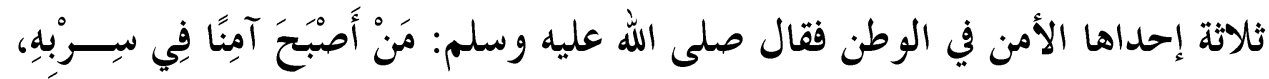

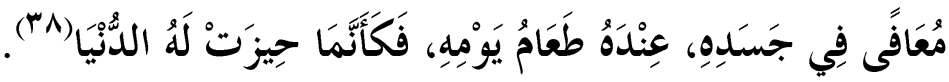


فانظر كيف جعل النبي صلى الله عليه وسلم الأمن في الوطن ركنا ركينا مــن

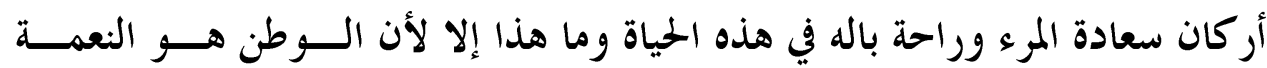
القريبة للإنسان لأنه مستقر حياته كرامته من كرامته وعزته من عزته به يعرف وإليه ينتسب ومن ذا الذي يستطيع أن يحيا حياة هانئة بلا وطن ويكفي أن الإنســان إذا أردت أن تجرح كر امته عيرته بأن لا وطن له.

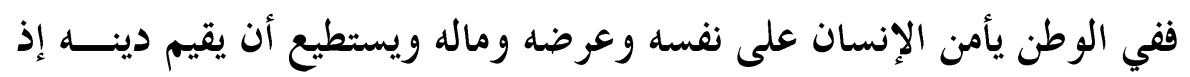
لا نفس ولا عرض ولا مال ولا دين بال وطن وقد أولى القر آن الكريم عناية فائقـــة لمذا المنحى من التعامل مع الوطن في آيات بينات مضيئة منه.

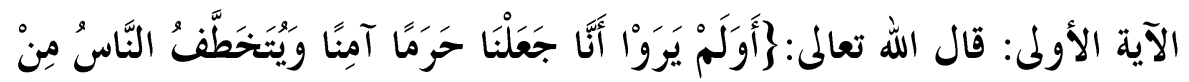

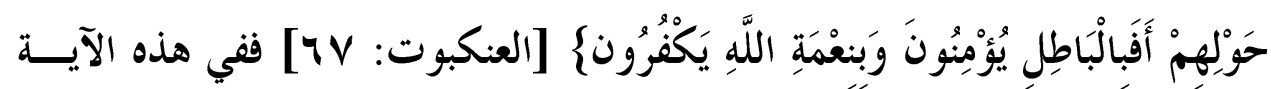

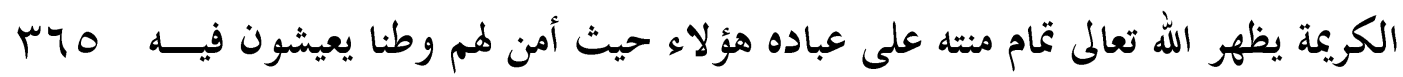

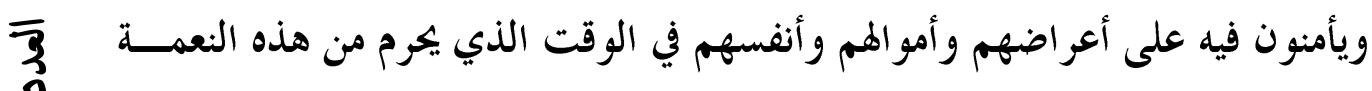
$\frac{3}{6}$

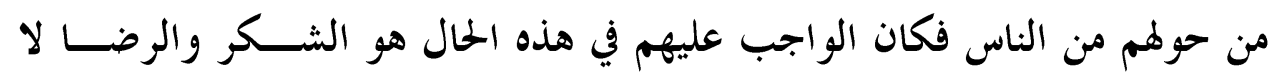

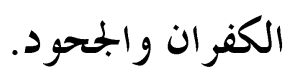

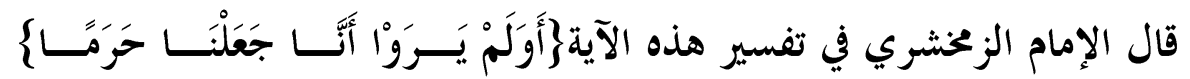
[العنكبوت: TV] كان العرب حول مكة يغزون ويتغاورون ويتناهبون وأهل مكـــة مستقرون فيها آمنون لا يعتدى عليهم مع قلتهم وكثرة غيرهم فذكرهم الله تعسالى

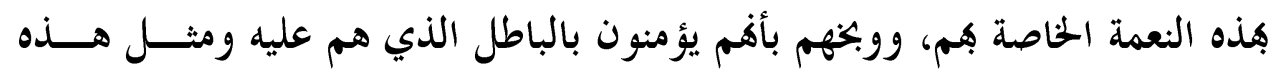

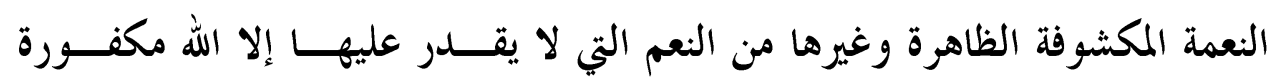

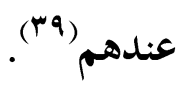
وقال الشيخ طنطاوي رحمه الله مشيرًا إلى هذا المعنى: والمعنى أجهـــل هــؤلاء

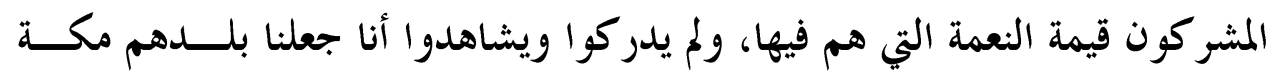


حرمًا آمنًا يأمنون فيه على أنفسهم وعلى أمو الفم وعلى أعر افهم والحال أن النــاس

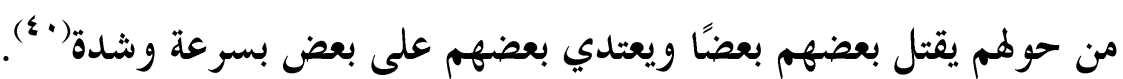

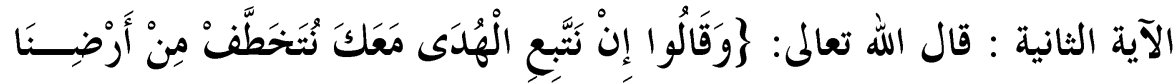

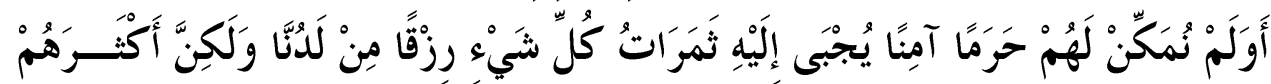

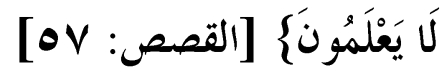
ففي هذه الآية الكريمة أيضًا منة من منن الله تعالى على أهل مكة بأن مكـــن الله

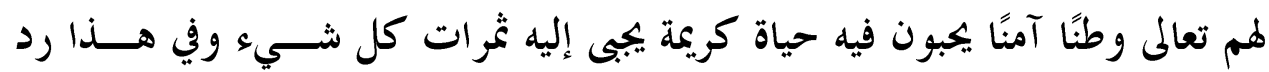

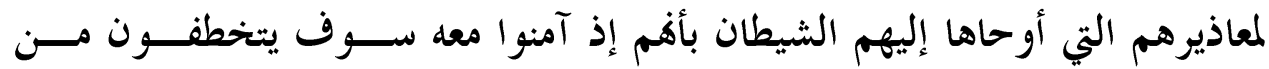

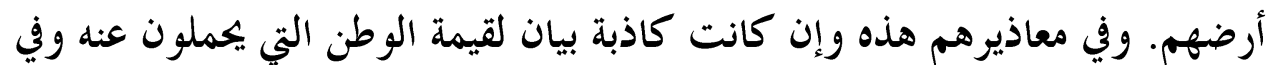

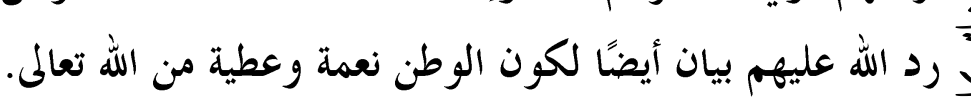

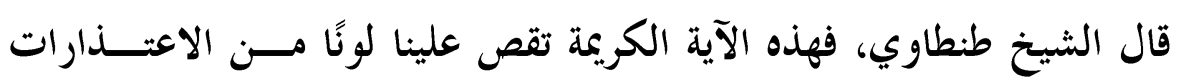

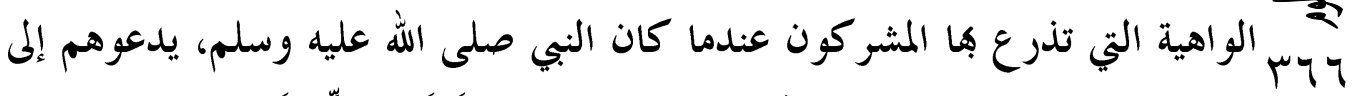

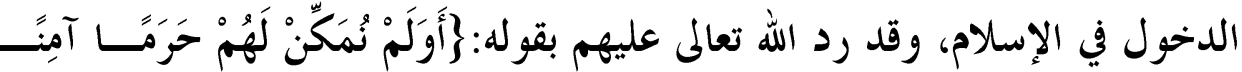

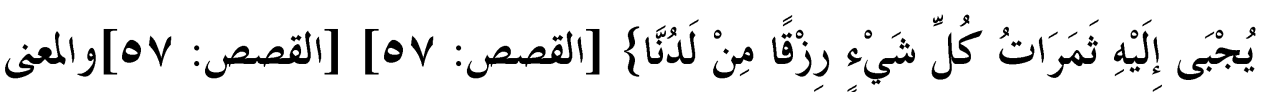
$\overline{3}$

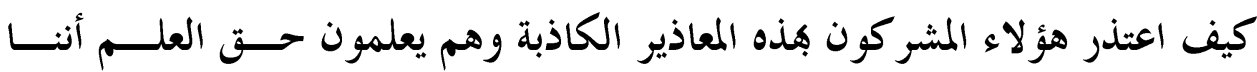
بفضلنا وإحساننا قد جعلنا لمم حرمًا ذا أمان يعيشون من حوله، وتــأتيهم خــيرات

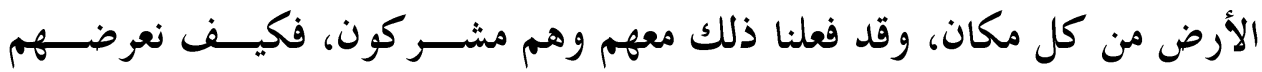
للخطف والعدوان عليهم وهم مؤمنون (1). قال الإمام الزمخشري مشيرًا إلى نعمة الله تعالى عليهم بالأمن في الوطن: كــــان العرب في الجاهلية حولمم يتغاورون ويتناحرون، وهم آمنون في حرمهم لا يخسـافون،

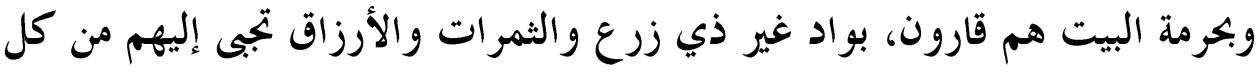




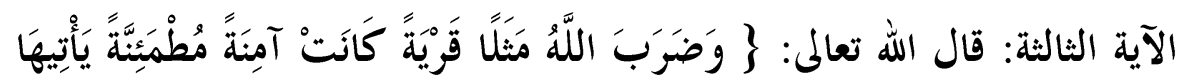

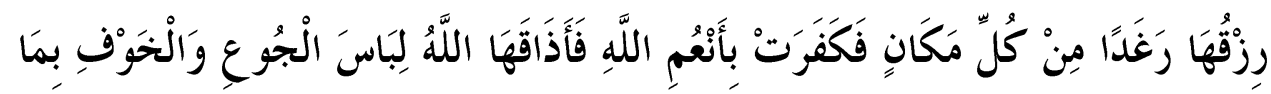
كَائوا يَصْنُعُونَ

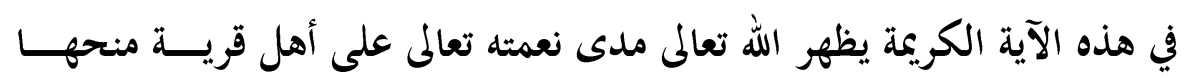

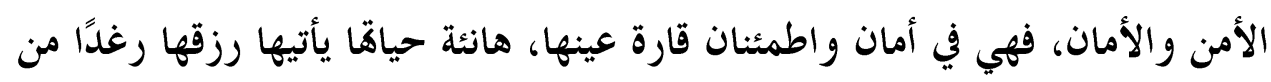

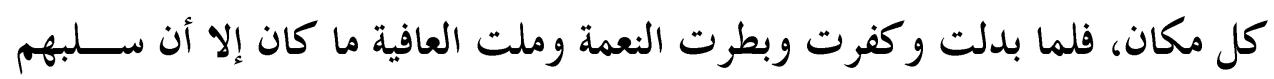
الله تعالى هذه النعمة العظيمة، وفي قوله تعالى:

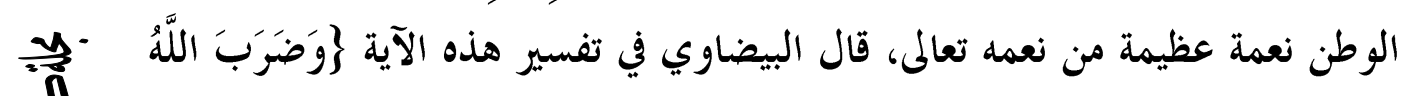
$\frac{5}{5}$

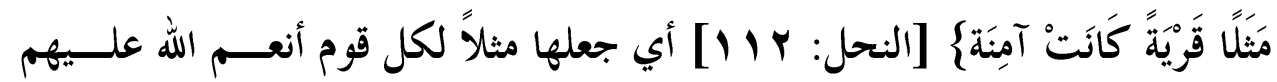

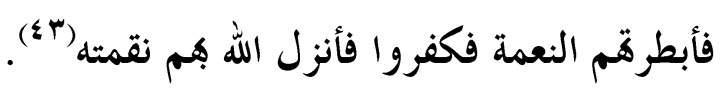

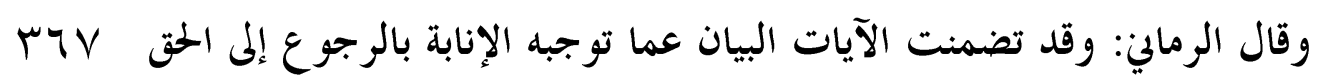

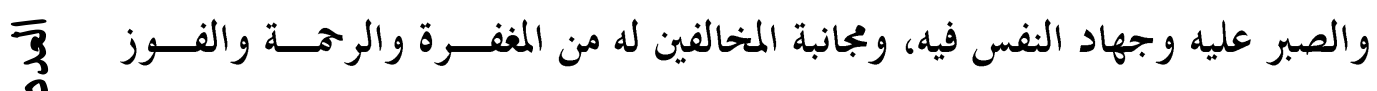

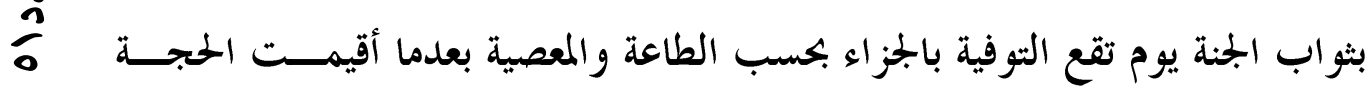
وأزيحت العلة (๕ \&).

وإلى هذا المعنى أشار الإمام القاسيمي في محاسن التأويل(ه ؛).

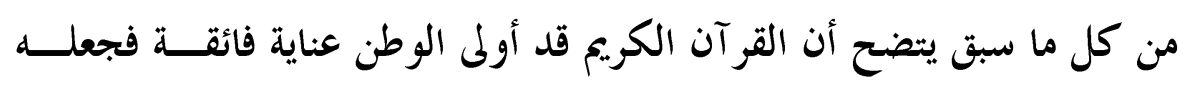

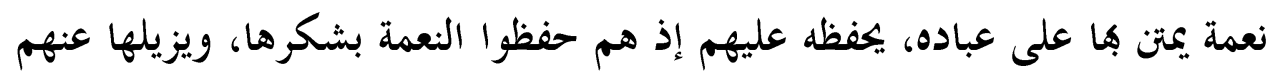

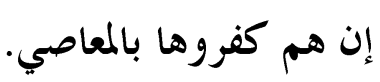

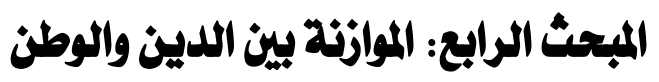

سبق في المبحث الأول أن تحدثت عن تباين الأفهام في مكانة الوطن وقيمتسائسه،

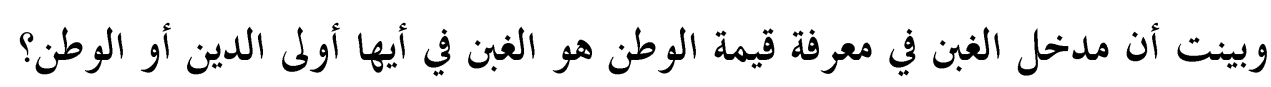

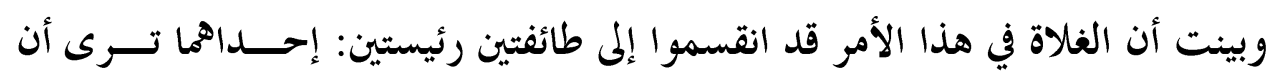
الوطن لا يعدو أن يكون حفنة تراب. 
والثانية ترفع الوطن فوق كل مقدس، ولا ترى أن شيئًا كائنًا ما كان يســـبقه ولو كان هذا الشيء هو الدين. فكان لزامًا في هذا المبحث أن نتكلم عن الموازنة بين الانتماء للدين والانتمـــاء للوطن. والحقيقة أنه لا تعارض ولا تناقض بين الانتماء للدين والانتمـــاء للـــوطن في

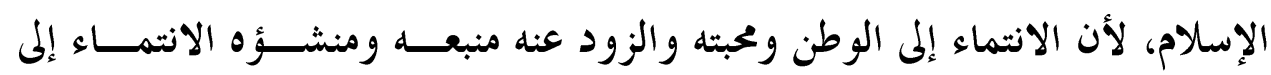
الإسلام، فالانتماء للوطن يستمد قواعده من الثريعة وعلى أساسها، فهــــو انتمــــاء

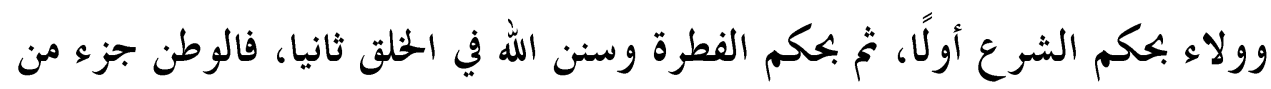

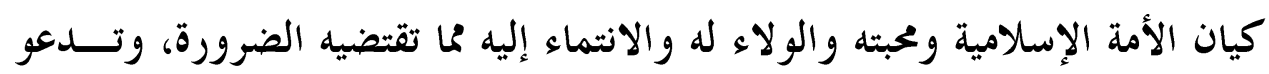

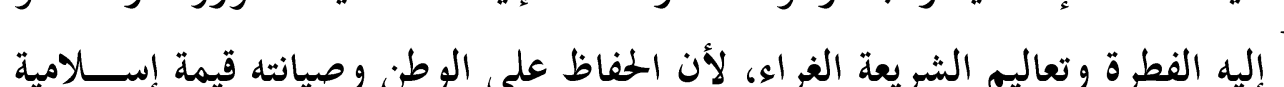
إلِّ إليه الفطرة وتعاليم الثريعة الغراء، لأن الحفاظ على الوطن وصيانته قيمة إســالامية 年

وليس هناك حرج في تعدد الانتماءات شريطة ألا يطفى واحد منها على باقيها، رفيعة. فكما أنه بحكم العقل ليس هناك من تعارض بين محبة الرجل لأبيه ومحبته لأمه، كذلك ليس هناك تعارض بين انتماء الإنسان لأسرته، وانتماء الإنسان لعائلتــه، وبلدتــهـ، 产 ودينه، فهي دوائر متداخلة بعضها أعم من بعض، فانتماء الإنسان لدينه لا يعــارض مجال انتمائه لوطنه، وانتماؤه لوطنه لا يعارض بحال انتماءه لأسرته وبيته وهكذا.

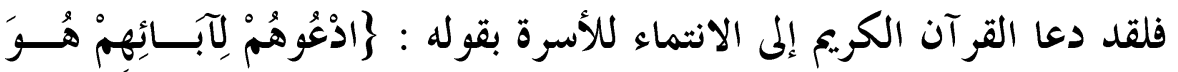
أَقْسَطُ عِنْدَ اللَّهِ ؛ [الأحزاب: 0] كما بين قيمة الروابط التي تكون بين أولى الأرحام

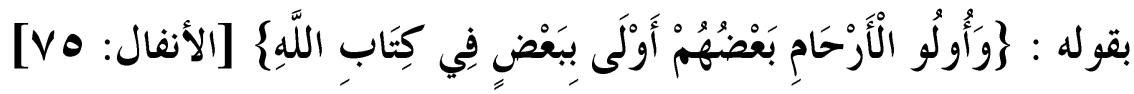
كذلك بين القر آن في الكثير من الآيات قيمة انتماء الإنسان لوطنــه ولدينــه، فهذه دوائر متعددة، وليس هناك تعارض بين هذه الدوائر ، كما لا يمكن فصل بعضها عن بعض أو قصر انتماء الشخص إلى واحدة من تلك الدوائر. 
فالمسلم يحب أسرته، ويحب بلدته، ويحب وطنه، ويحب دينه، وإذا كان الــدين

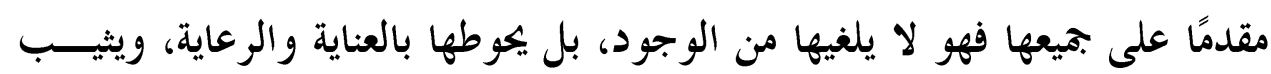
على تحقيقها، ويعلي من قدر محققيها. محبة المنعم مقدمة على محبة النعمة

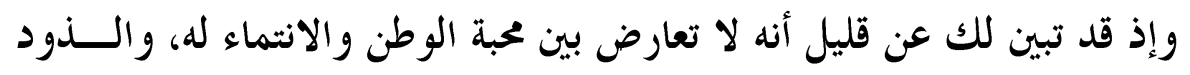

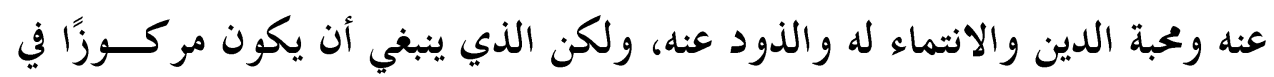

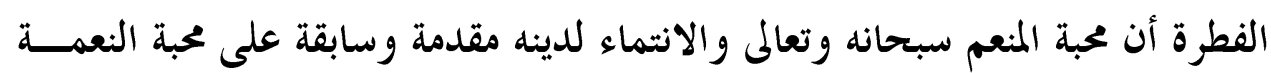

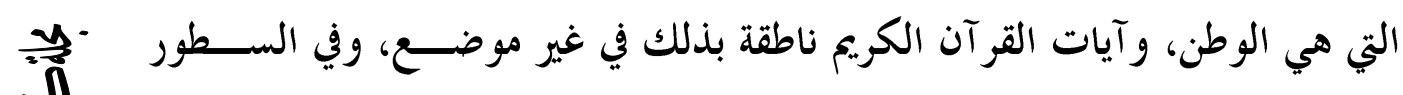
: الآتية وقفات مع آيات القر آن الكريم التي تجلي هذه الحقات الحقيقة. 害

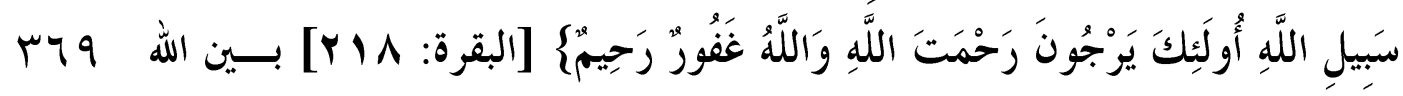

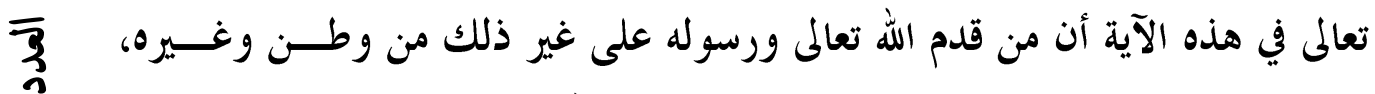

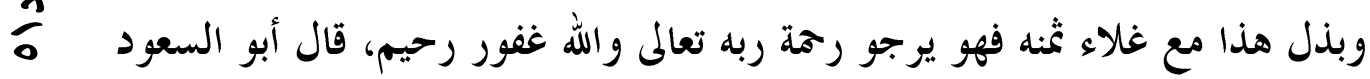

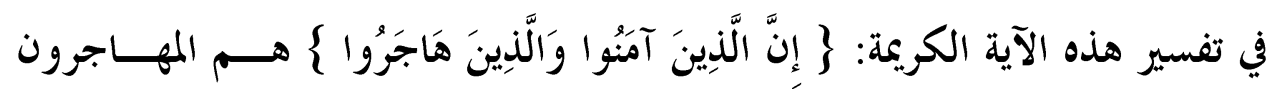

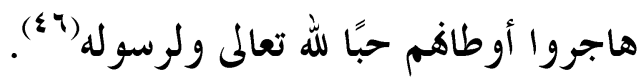

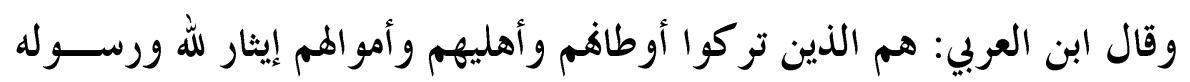

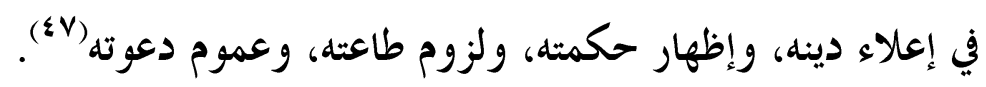

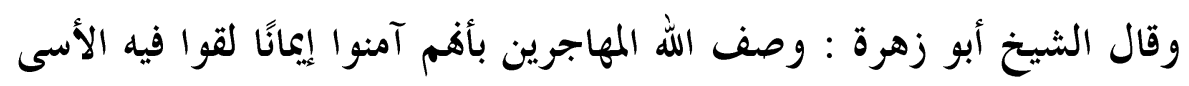

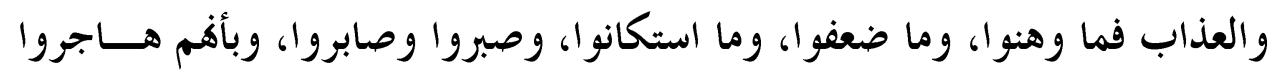

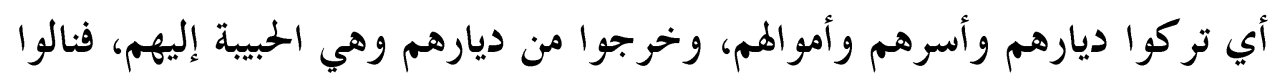

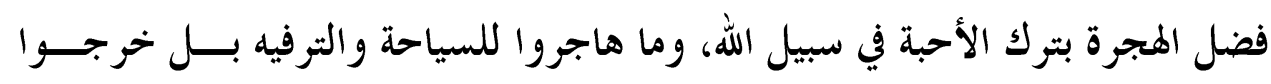

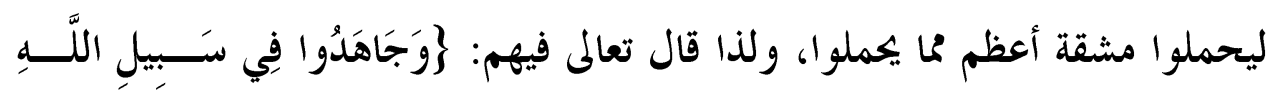

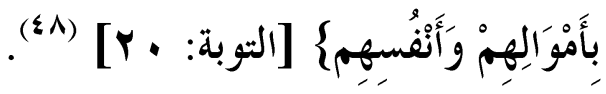


ففي ثناء الله تعالى عليهم وقد تركوا الوطن في سبيل الدين ما يظهر أن الــدين مقدم على الوطن في حال تعرض دين المرء لسوء في وطنه.

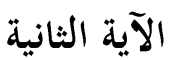

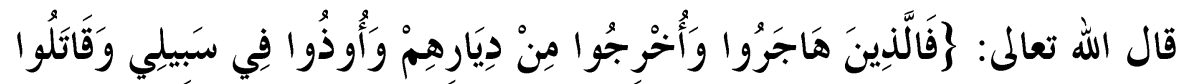

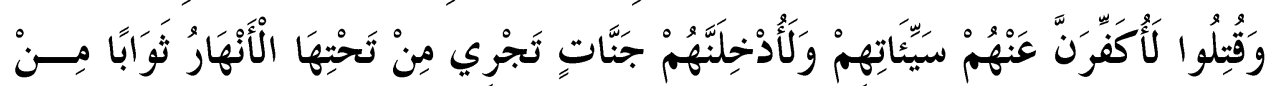

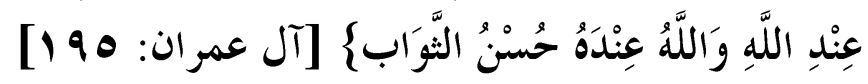

وفي هذه الآية أيضًا إشارة إلى أفضلية من يوازن بين الأشياء فلا يغلب عنســده

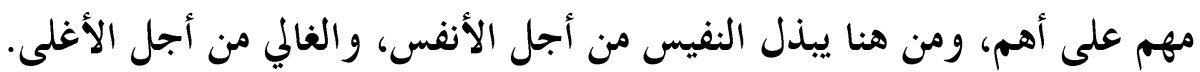
قال الزخشتري في تفسير هذه الآية: تفضيل لعمل العامل منهم علــى ســبيل

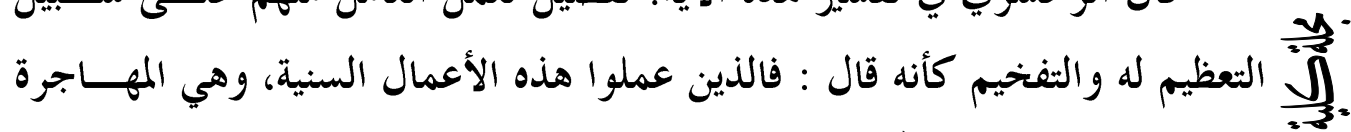

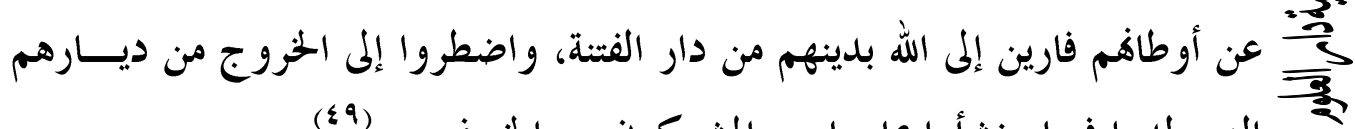
•

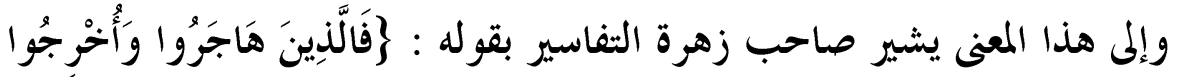

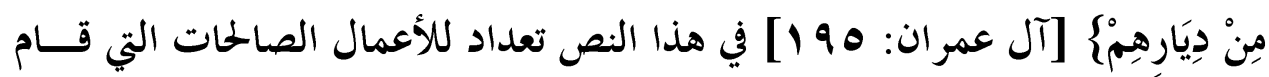
$\overline{3}$

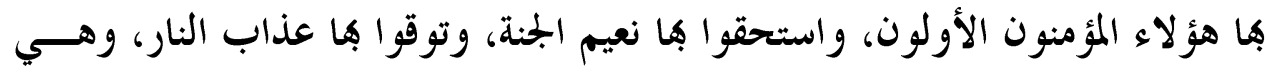
أمور ثلاثة آخذ بعضها بحجز بعض ومتلاقية في معناها ومغز اها، أول هذه الأمور أفم الفم

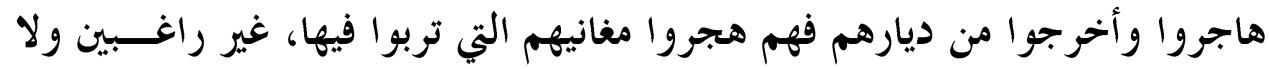

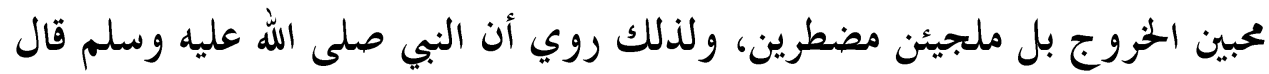

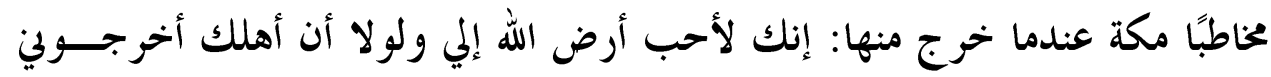

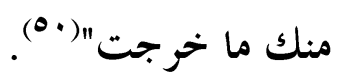

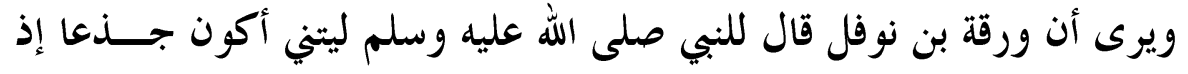

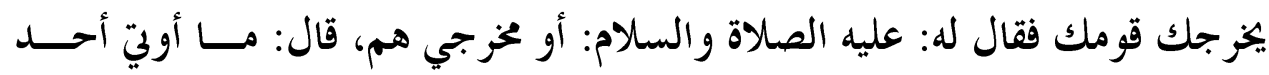




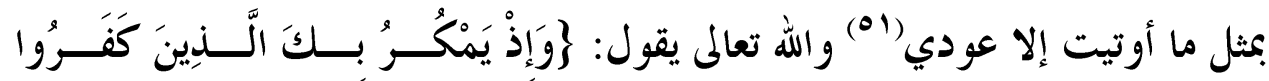

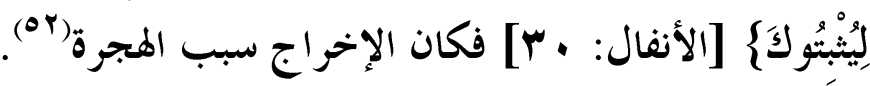

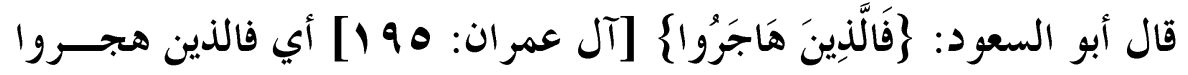

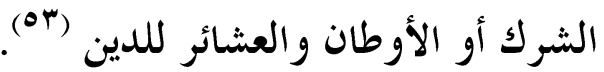

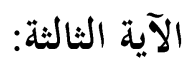

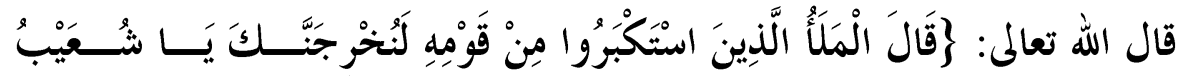

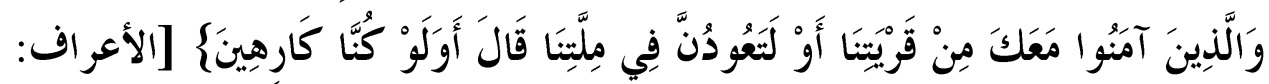

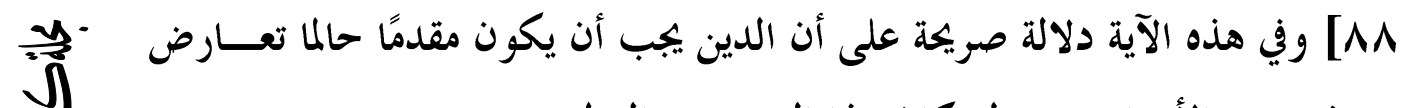

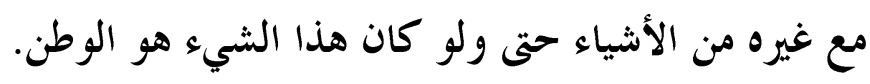

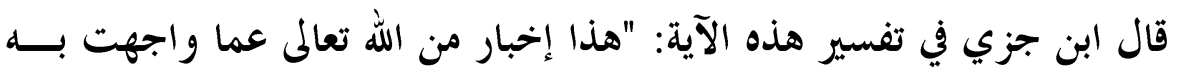

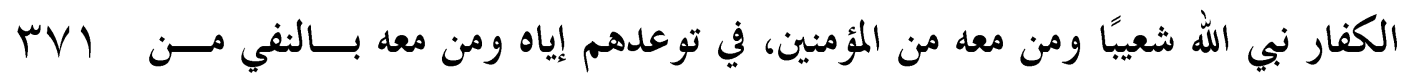
$\overline{3}$

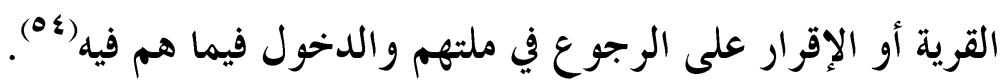

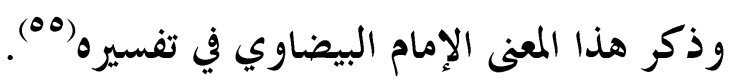

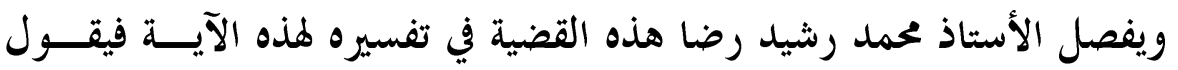

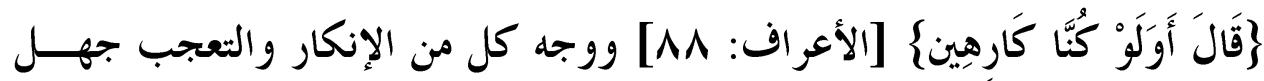

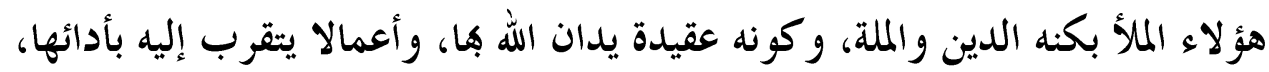

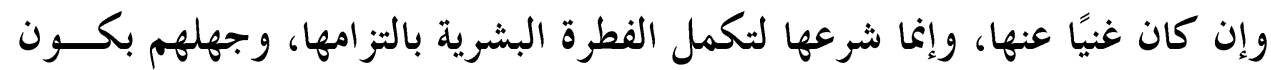

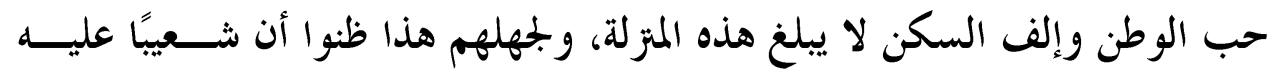

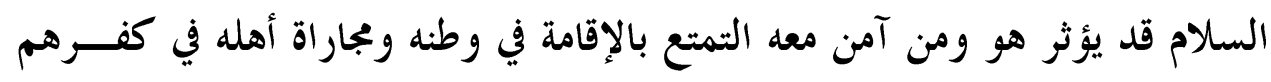

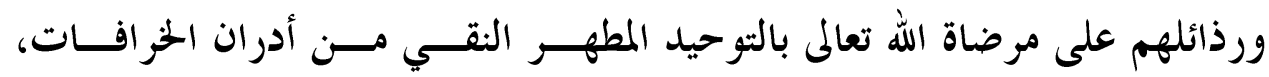

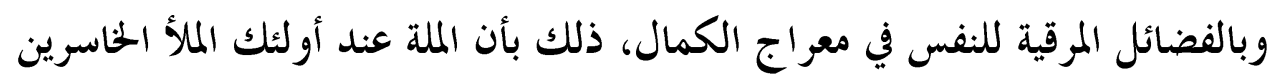
رابطة تقليدية وعصبية قومية يجري أصحابها منها على قول الشاعر :

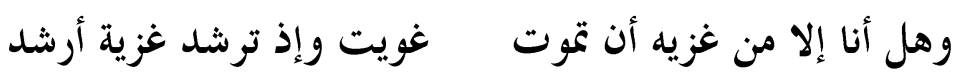


وملة الرسل ليست كذلك، بل هي دين مالك للنفس حاكم على الوجـــدان والعقل يقصد به الكمال البثري الأعلى بععرفة الله تعالى والقرب منه، وما يتبع ذلك من صلاح الدنيا وسعادة الآخرة، فإن تمكن صاحبه من إقامته في وطنه وإصلاح أهله

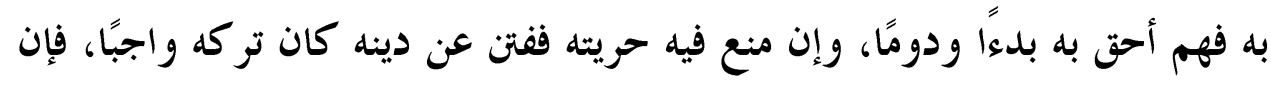

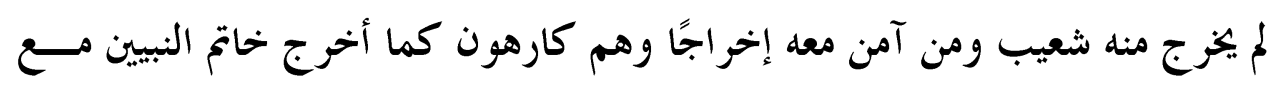
السابقين الأولين إلى الإسلام خر جوا مهاجرين كما فعل إبـــــاهيم عليــهـ الصـــلاة

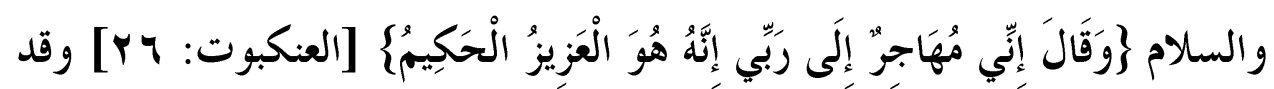
أوجب الله تعالم الهجرة على من يستضعف في أرض وطنه، فيمنع من إقامـــة دينـــه فيها، ويوجب المتعقبون للأوطان في هذا العصر الهجرة منـــها إذا منعـــوا حريتـــهم

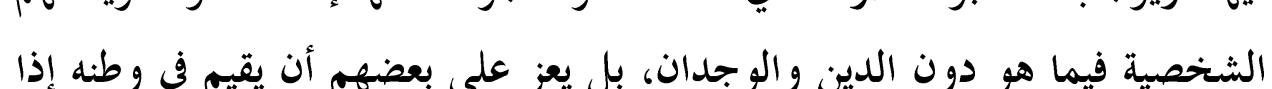

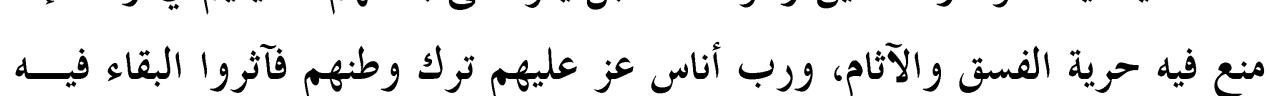

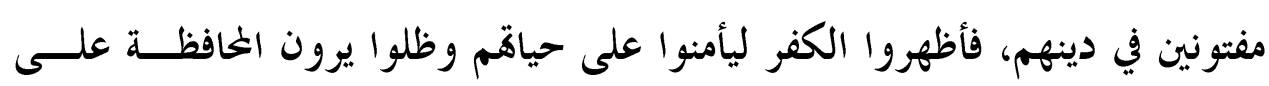
الإسلام في خاصة أنفسهم، ولكنهم لم يتمكنوا من تلقينه لأولادهم وتربيتهم عليــهـ فارتدت ذريتهم عنه في زمنهم، أو من بعدهم كما وقع لبعض مسلمي الأندلس مــن غل الأسبانيين لعرش دولتهم العربية وإكر اههم على الكفر أو الخُورج مــن الــبلاد $\frac{\sqrt{3}}{3}$ rVY

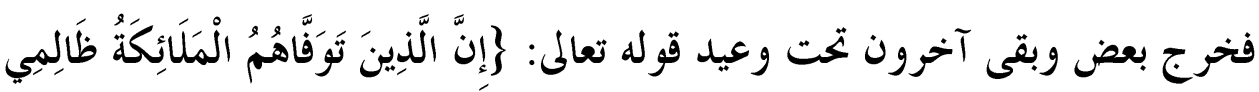

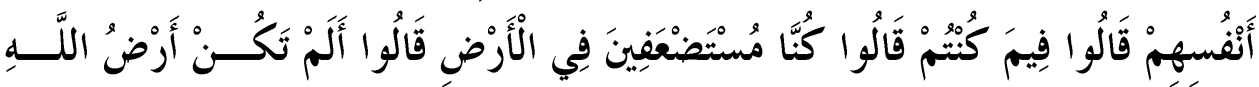

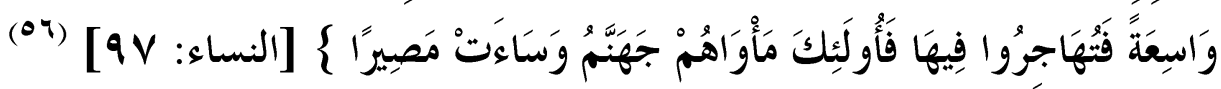
الآية الرابعة

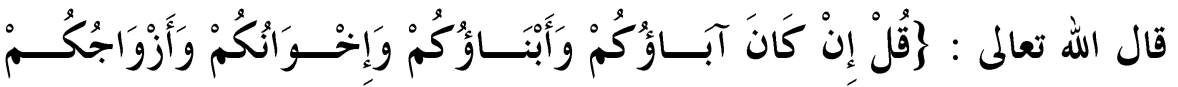

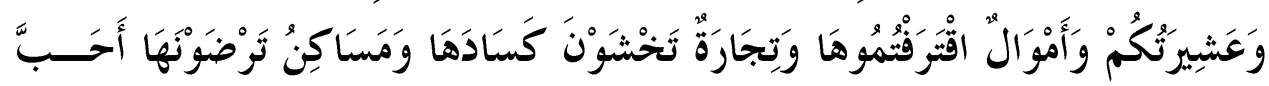

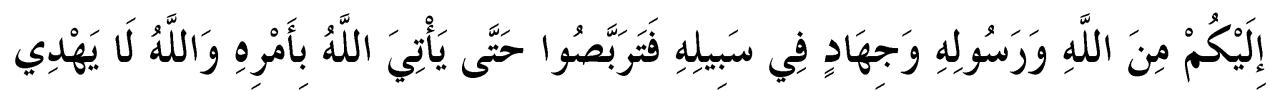

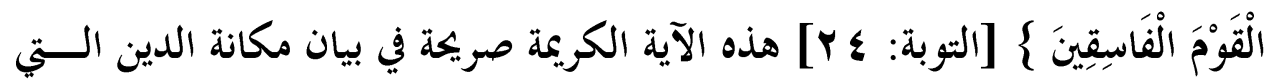


لا بد أن تكون في النفوس، أي لا يصح لأحد أن يفضل أبًا ولا أمُّــا ولا ابنَّا ولالا

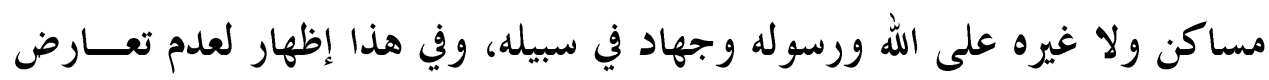

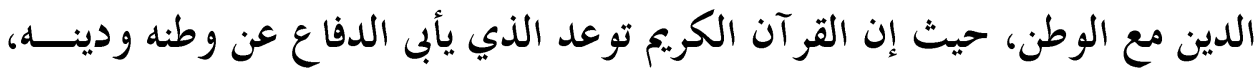

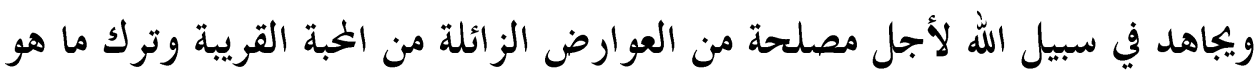

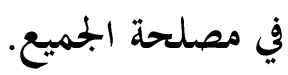

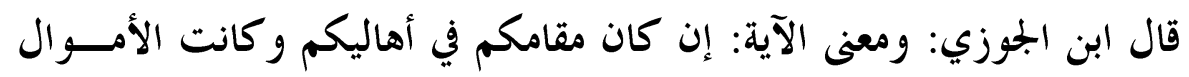

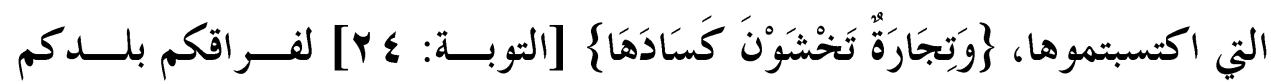

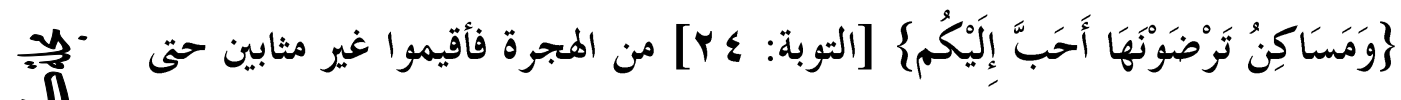
疍 تفتح مكة فيسقط فرض الهجرة .

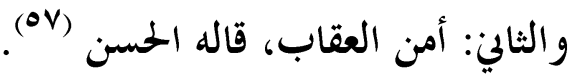

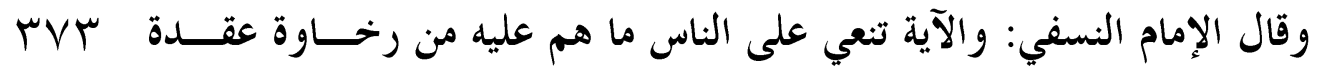

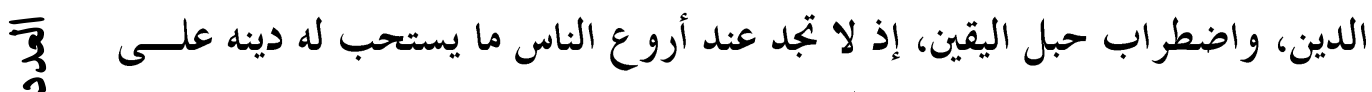
$\frac{2}{6}$

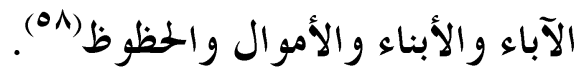

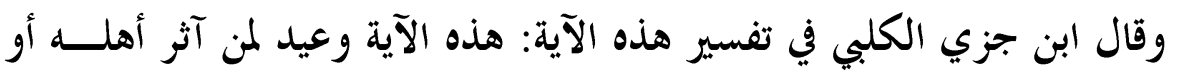
ماله أو مسكنه على الهجرة والجهاد (ه9). الآية الخامسة

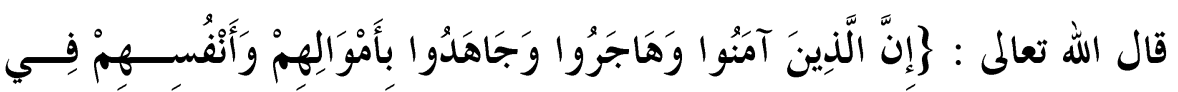

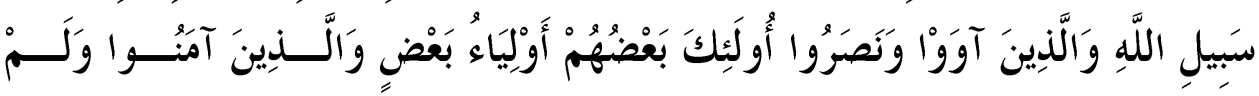

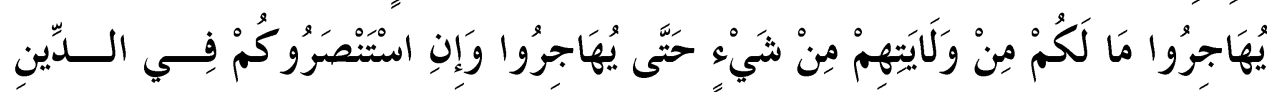

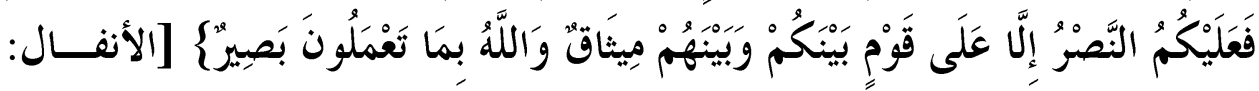

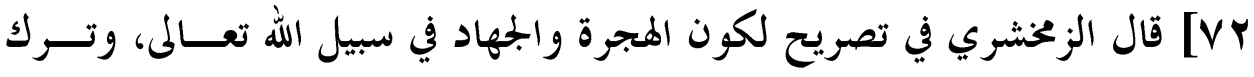

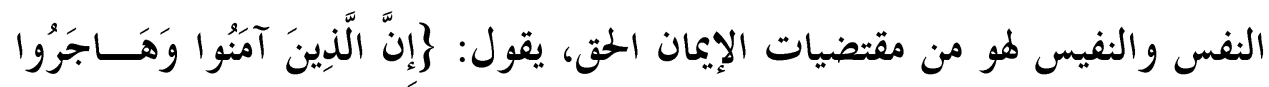

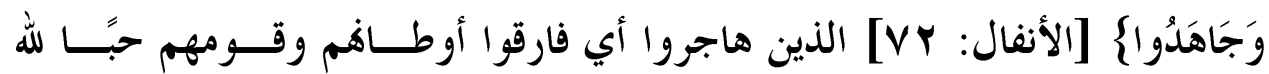


ورسوله هم المهاجرون، والذين أووهم ونصروهم على أعدائهم هم الأنصـــار...إلى

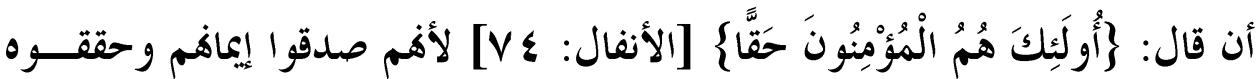
بتحصيل مقتضياته من هجرة الوطن، ومفارقة الأهل والانسلاخ من المـال لأجــل

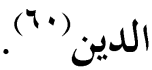

الآية السادسة:

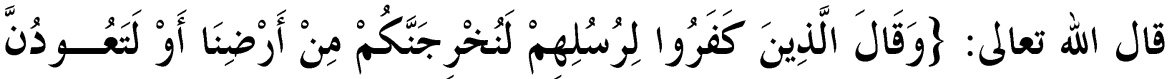

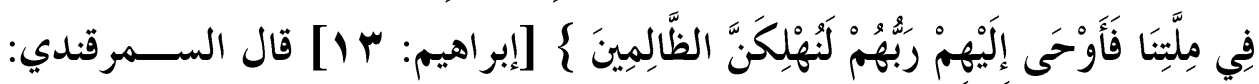

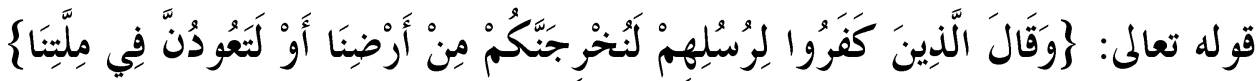

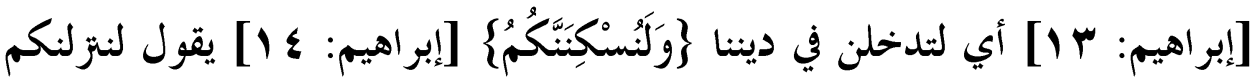

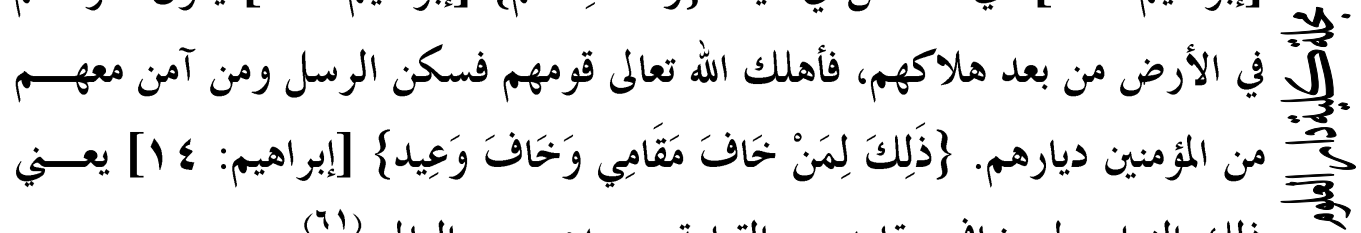
ذلك الثواب لمن خاف مقامه يوم القيامة بين يدي رب العالمين("ا"). فأنت راء كيف جازى الله تعالى من آثره على غيره حيث آثر البقاء على دينه

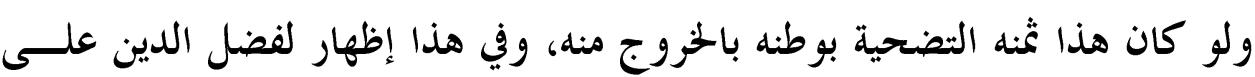
الوطن، وعدم نكران قيمة الوطن حيث إن الإنسان سوف يدفعه قيمة لأجل الدين. rVะ وقال النسفي في توضيح ذلك وعن

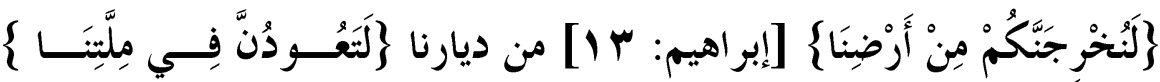
[إبراهيم: ب I] أي ليكونن أحد الأمرين: إخر اجكم أو عودكم وحلفوا على ذلك،

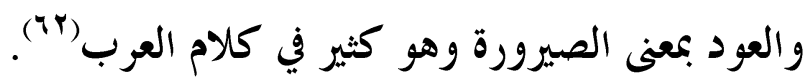
فهذه ست آيات تظهر أن الإسلام لا يعارض الانتماء للوطن، ولكــن يثمنسـه ويعرف له قيمتله، ولكن لا ينبغي أن يكون الوطن أعلى قيمة من الــدين في عقــل 
وهذه الآيات الكريمة ترد على من اختلفت مفاهيم الأشياء عندهم وتباينــت رؤيتهم فاختلت قيمة الأشياء أمام ناظرهم، ففضلوا النعمة على المنعم، ومثل هــؤُ لاء

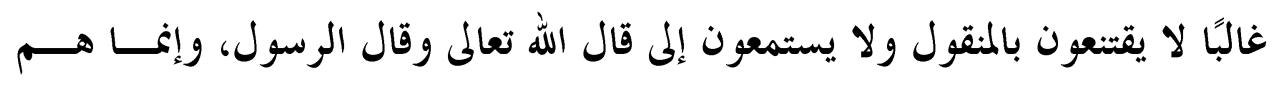

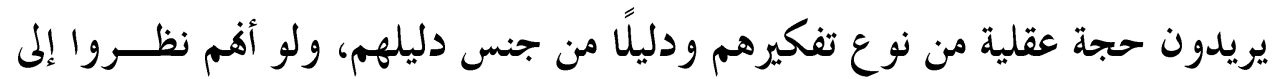

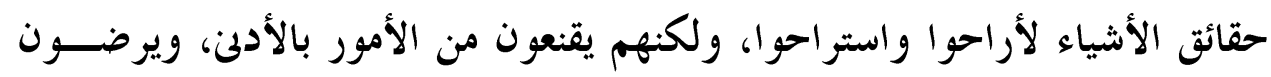

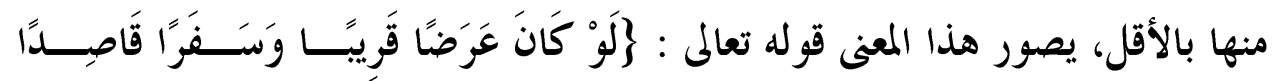

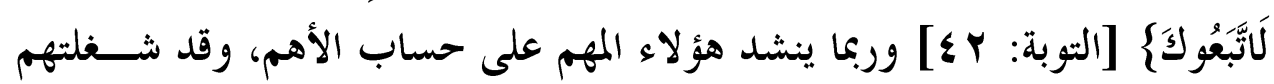

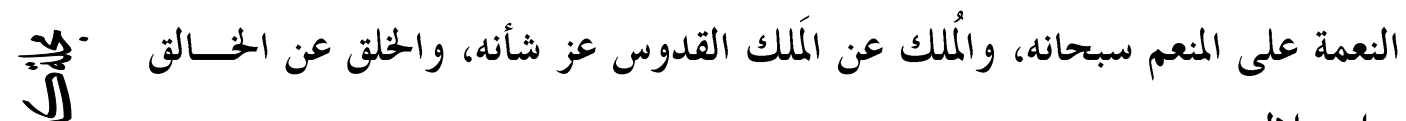

وهل الوطن والأهل إلا مظهرًا من مظاهر فضل الله سبحانه وبعض نعمثنه على

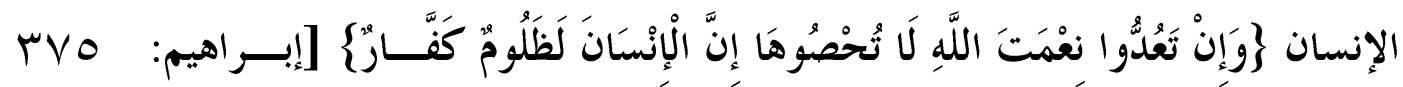

فإذا أبيت هذا وبان أن الوطن أثر من آثار نعمة الله تعالم، وجزء قليل من خير كثير أنعم الله به على الإنسان في صحته وماله، وأهله ووطنه، يكق لنا أن نتساءل أي الأمرين أحق بالحب وأولى بالانتماء النعمة أم المنعم؟ الفضل أم صاحب الفضل والمنة وخالق الكون وواهب الحياة("آ).

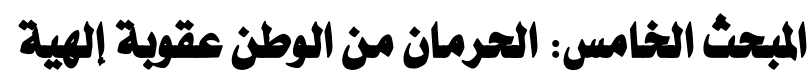

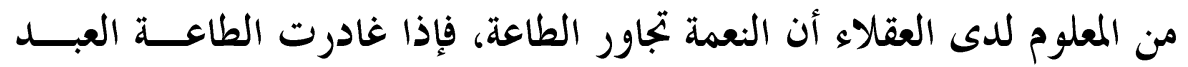

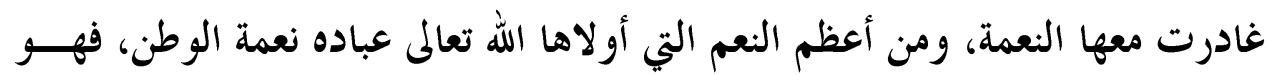
المأمن والمكمن، وهو المأوى والمثوى، وهو الملجأ والملاذ، وقد أظهرت آيات القرآن الكريم في الكثير من آياته أن كثيرًا من الأمم بدلوا وحرفوا وغــيروا فجـــازاهم الله تعالم بعقوبة تضاهي ذنبهم وهي الحروج من الوطن والحرمان منه، وفي السطور الآتية 
بيان لهذه الآيات الكريمة التي تناولت قيمة الوطن وكيف جازى الله تعلى بها من بدل

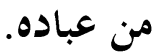

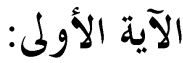

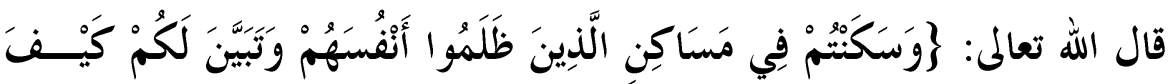

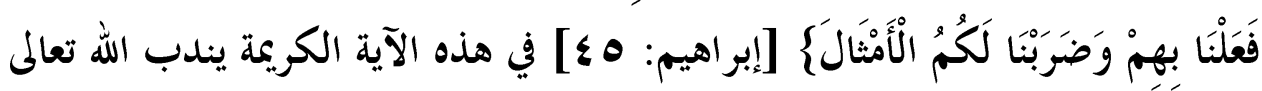

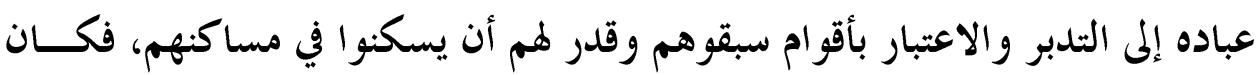

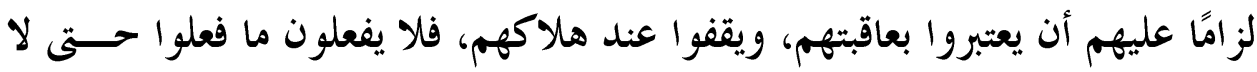
يصابو ابعصابكم.

قال ابن الجوزي رحمه الله في تفسير هذه الآية:

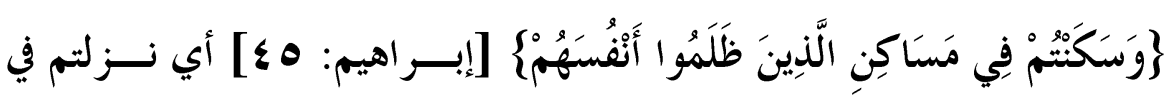

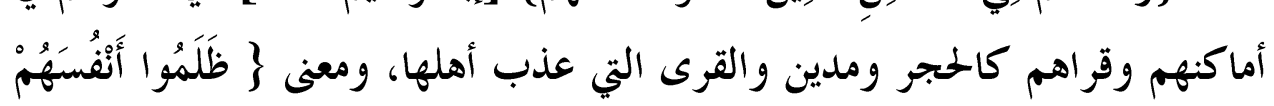
T

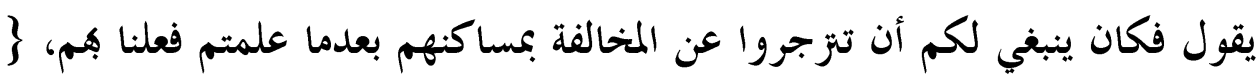

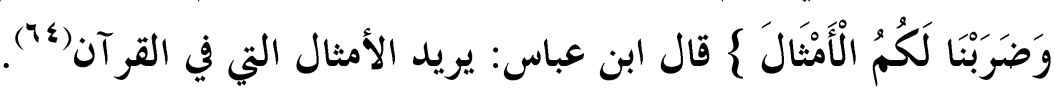

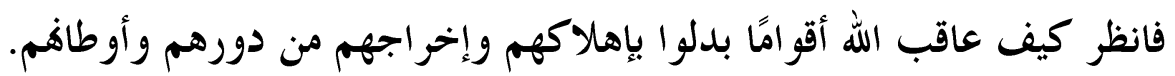

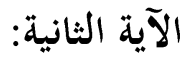

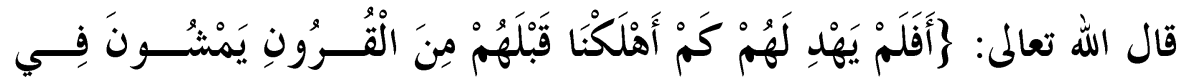

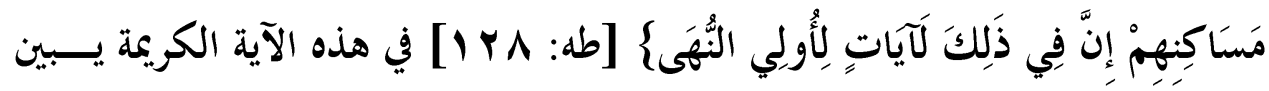

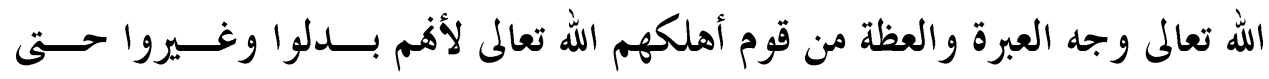

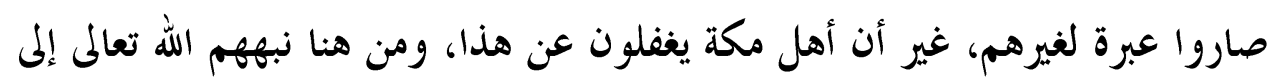
النظر في شأن هؤلاء حتى لا ينتهجو الفجهم.

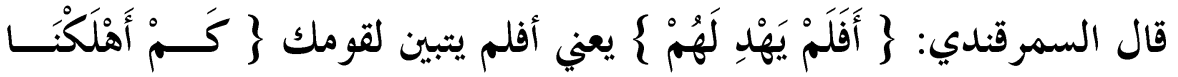

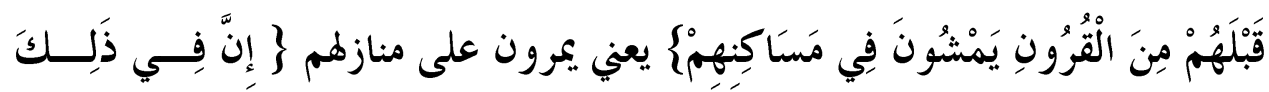




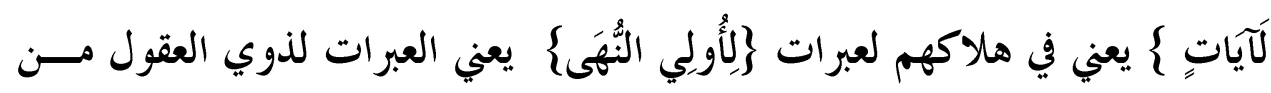
الناس.

وقال ابن الجوزي: "أي أفلم يتبين لكفار مكة إذا نظروا آثار من أهلكنا مـــن

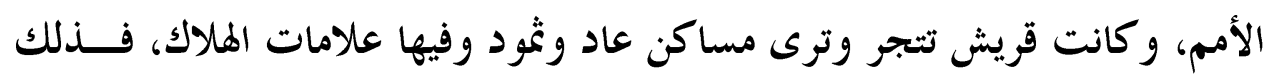

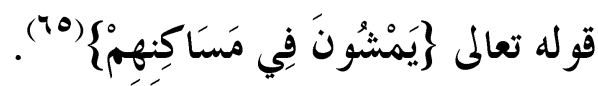

ولعل كلام الإمام النسفي أكثر صراحة من هذا، عندما قال :"يريد أن قريشًا

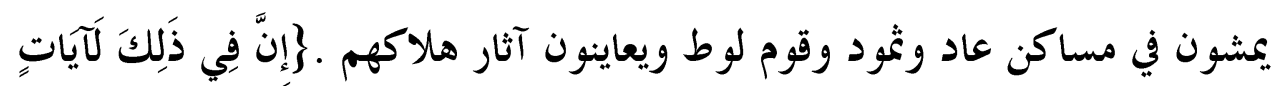

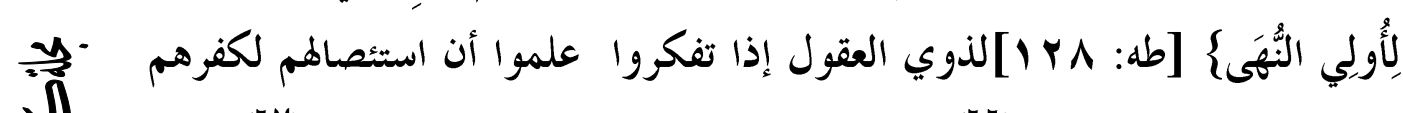
$\sqrt{3}$

高

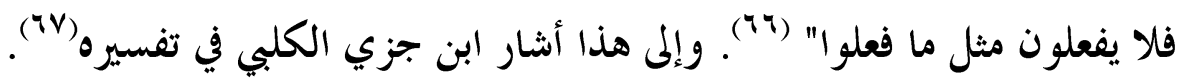

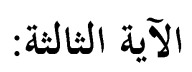

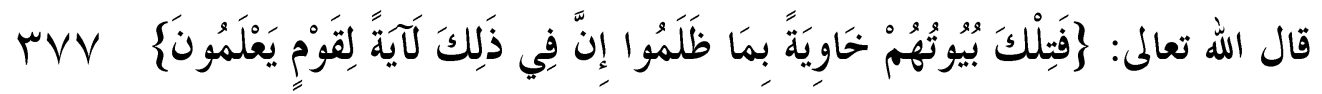

$\overline{3}$

[النمل: [or]

وفي هذه الآية يظهر الله تعالى خلاء بيوت الظالمين بشــــؤم ظلمهــــم وعاقبـــة

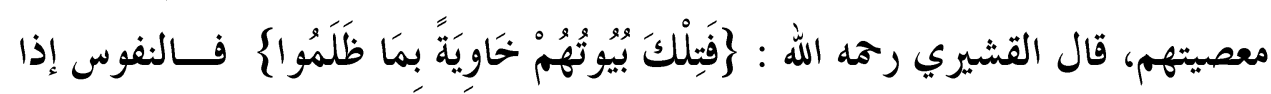

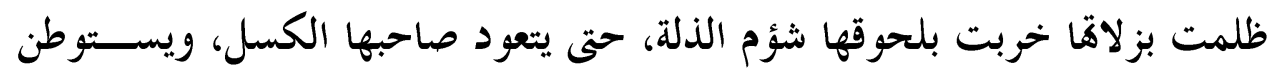

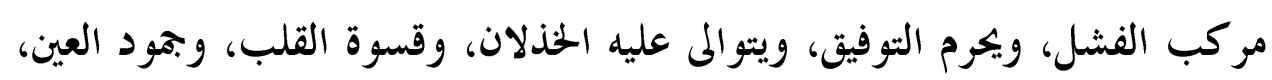

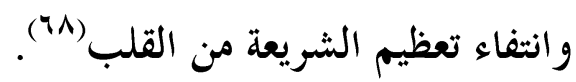
قال الشيخ طنطاوي رحمه الله: والذي يتدبر القر آن يرى في كثير مـــن آياتسهـ

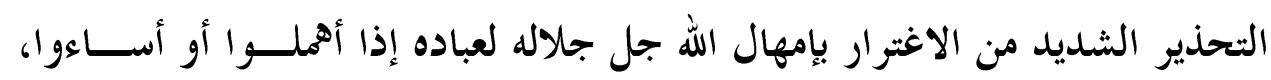

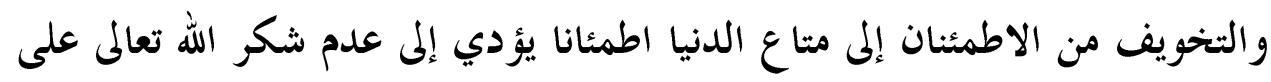

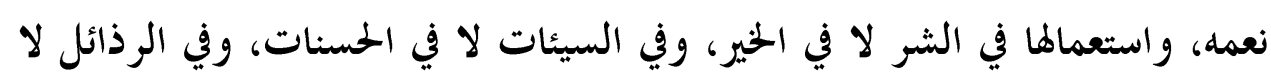

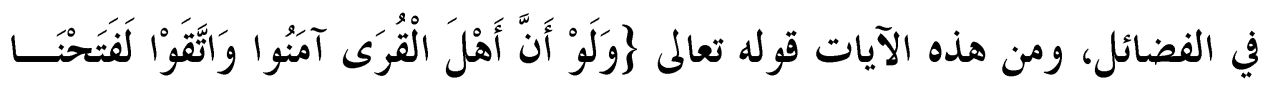




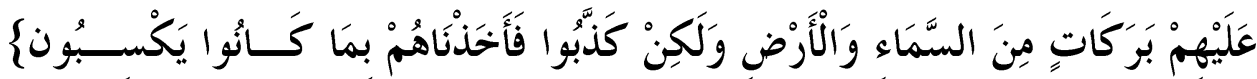

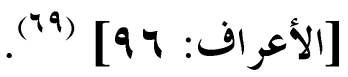

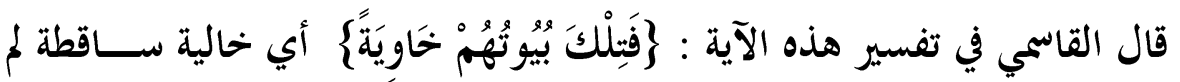

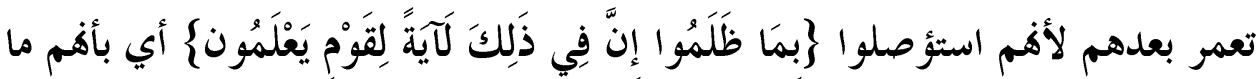
أخذوا إلا لظلمهم وإن عاقبة الظلم الحرمان والبوار (v•).

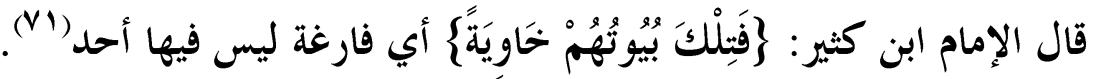

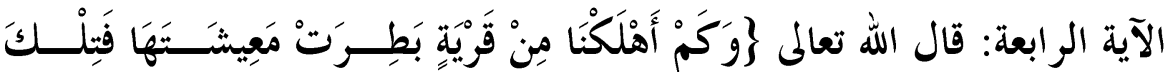

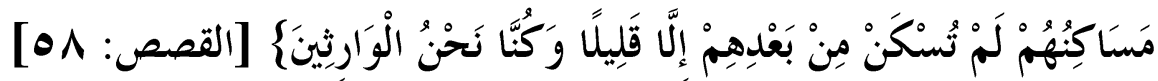

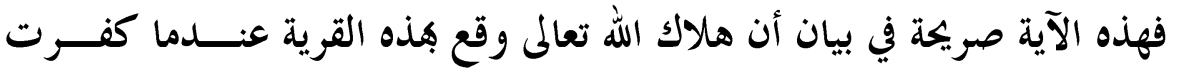

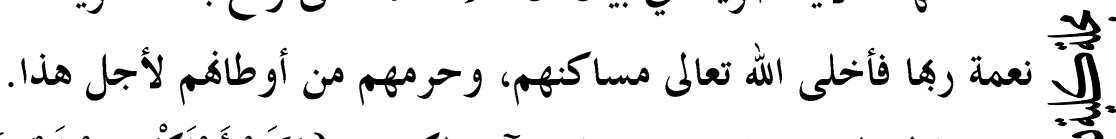

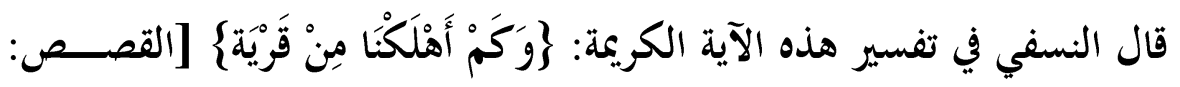

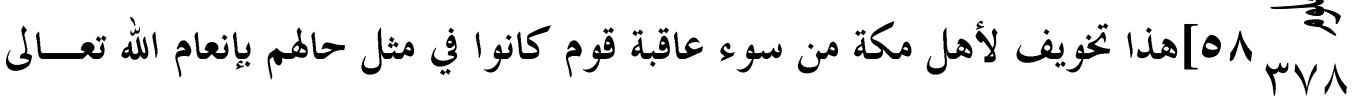
عليهم فلم يشكروا النعمة وقابلوها بالبطر، فأهلكوا، والبطر سوء احتمال الغــنى،

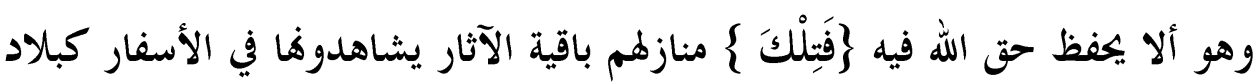
تثود وقوم شعيب وغيرهم (Vr) $\overline{3}$

قال ابن عباس: لم يسكنها إلا المسافرون، ومار الطريق يوما أو ساعة، والمعنى لم إلم

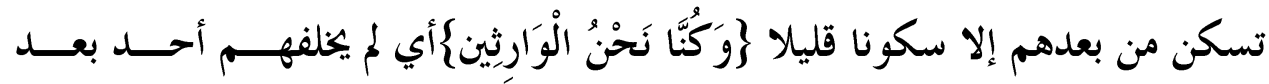

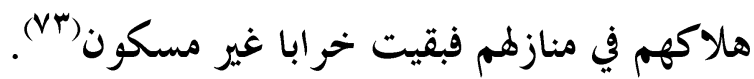

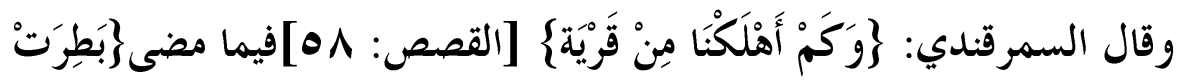

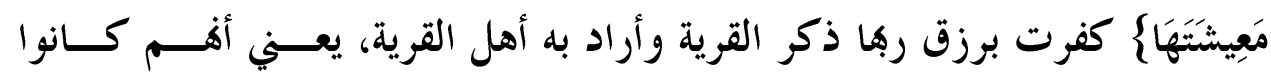

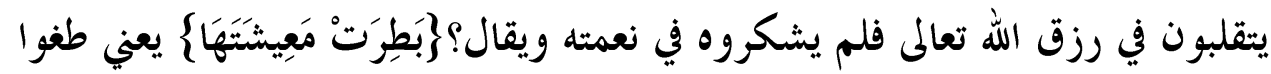

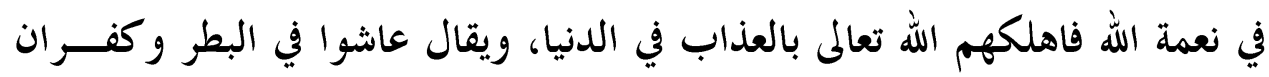

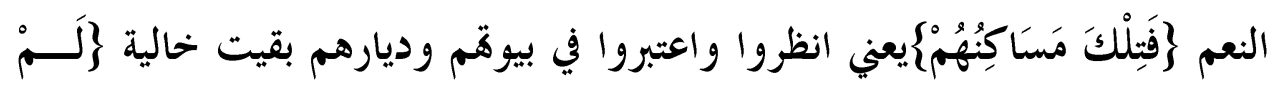




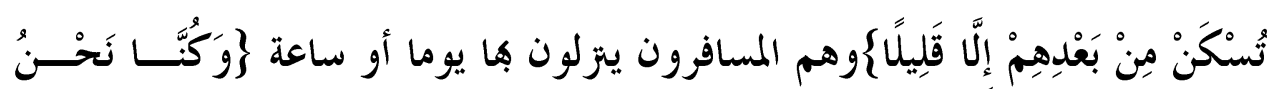

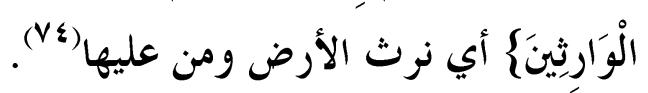

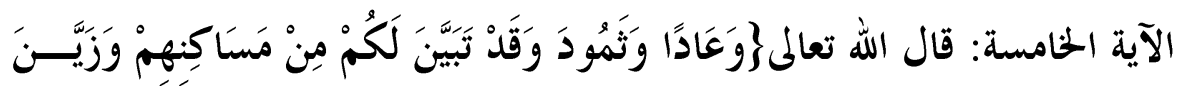

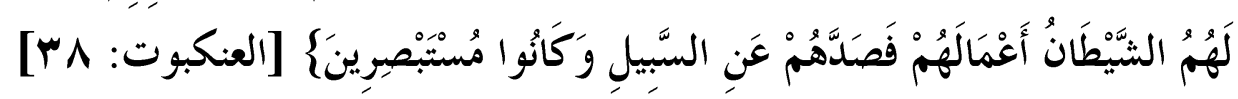

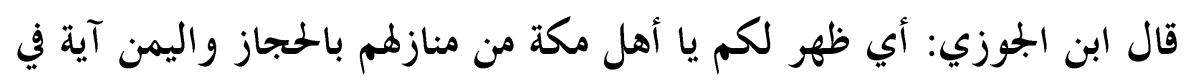

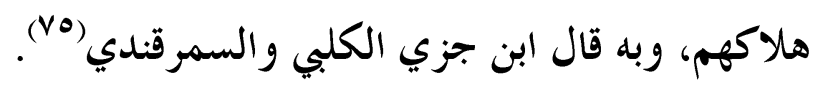

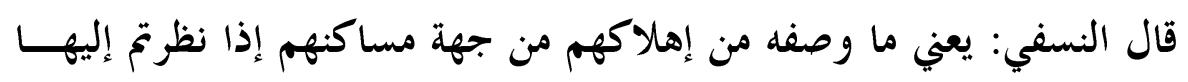

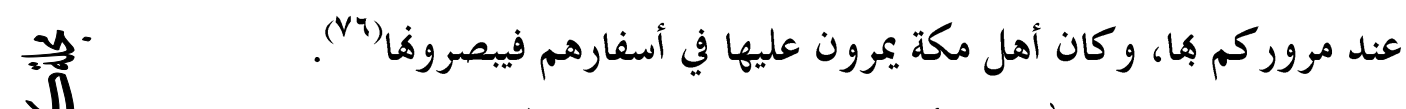

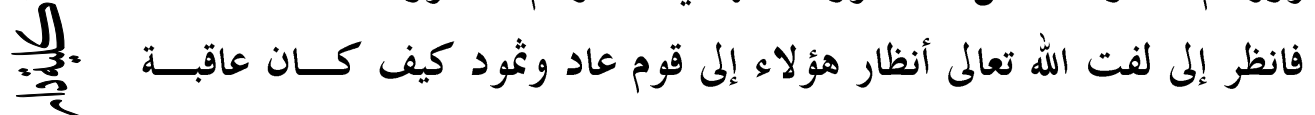

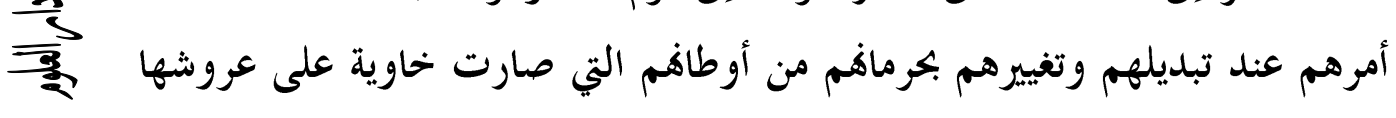
rvq وقد رأى أهل مكة هذا رأي العين.

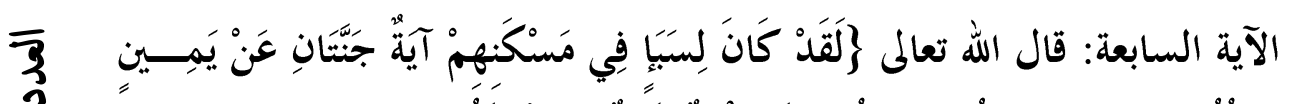

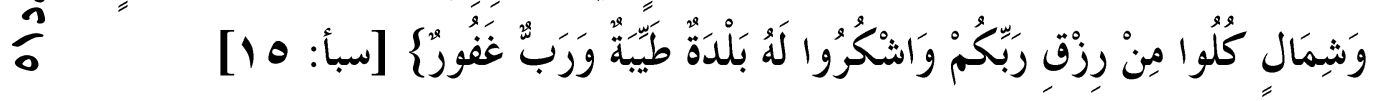

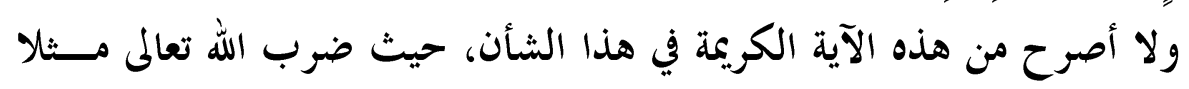

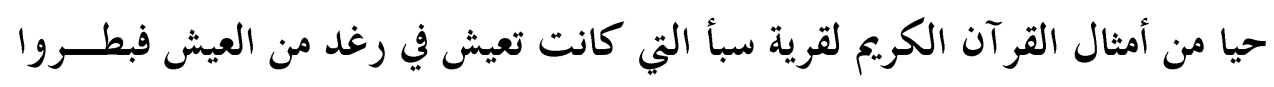
النعمة وملوا العافية فكان عاقبتهم خسرا.

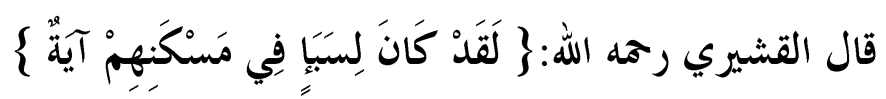

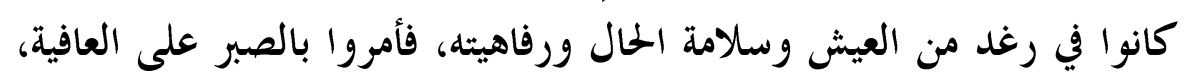

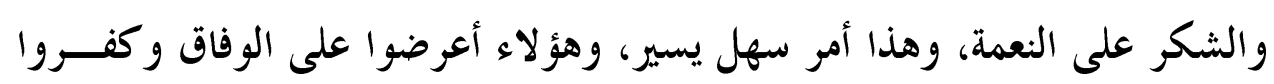
بالنعمة وضيعوا الشكر فبدلوا وبدل بهم الحال كما قالوا

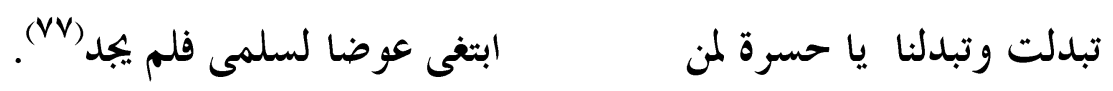

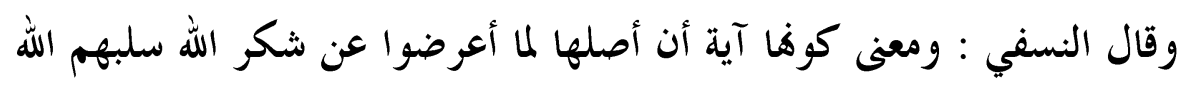

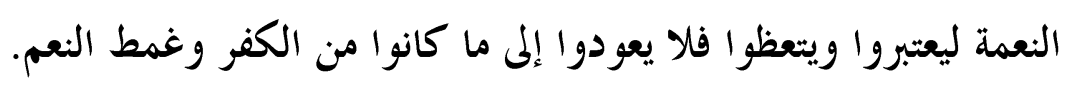


أو جعلها آية أي علامة دالة علــى قــــرة الله تعــالى وإحســـانه ووجـــوب

$$
\text { شكرون) ( }
$$

قال الشيخ طنطاوي: وشبيه هذذه الآية الكريمة في أن كفران النعم واسـتعمالها

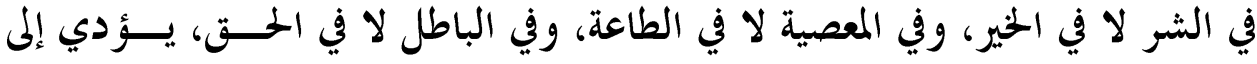

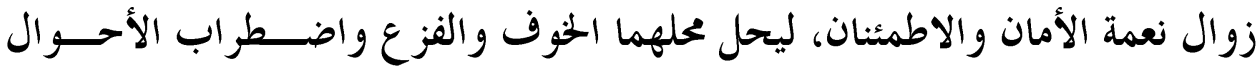

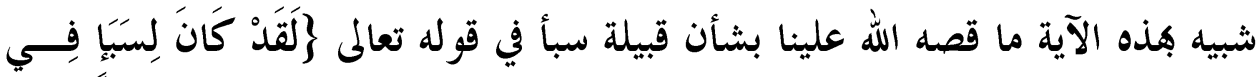

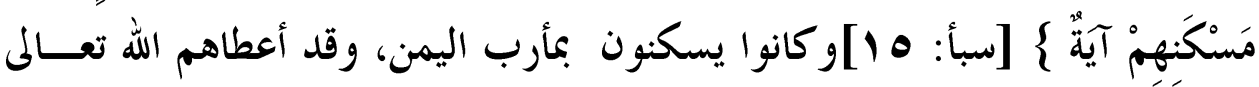

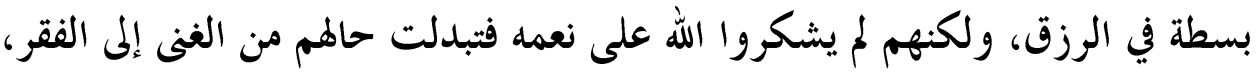

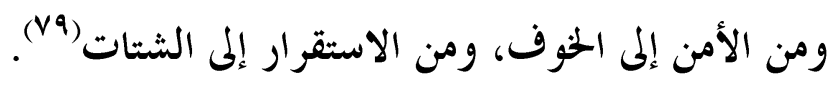

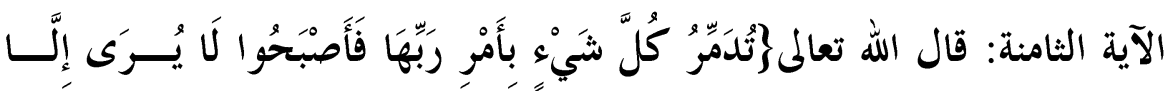

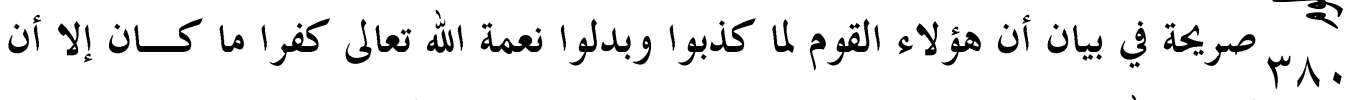

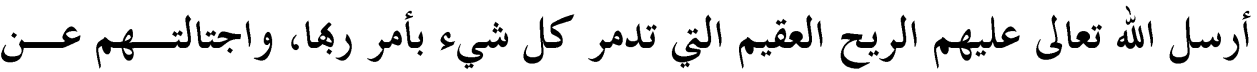

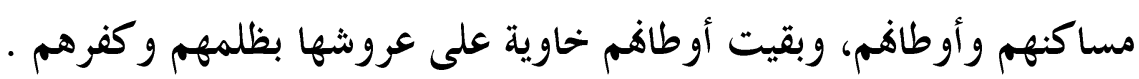

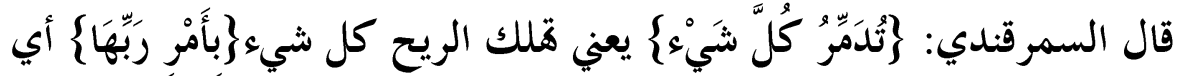

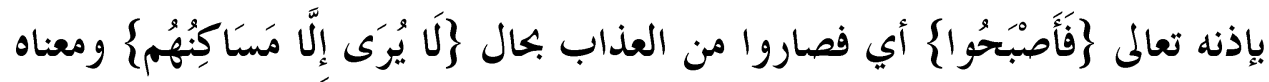

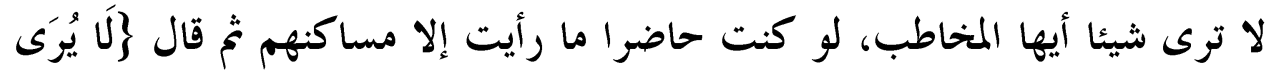

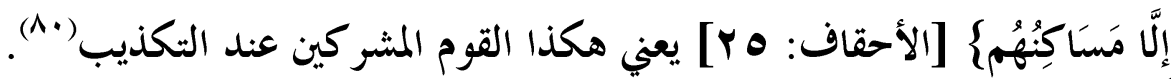

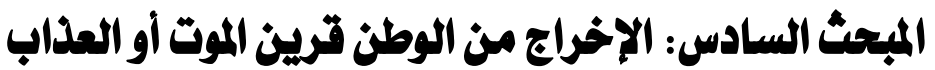

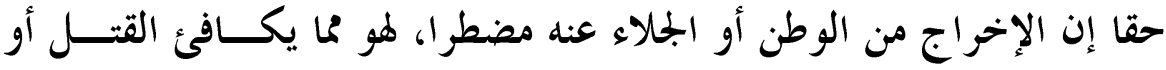

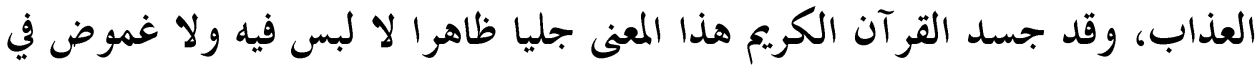

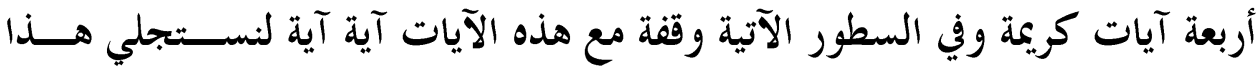
الفهم القرآي من كلام المفسرين حول هذه الآيات 


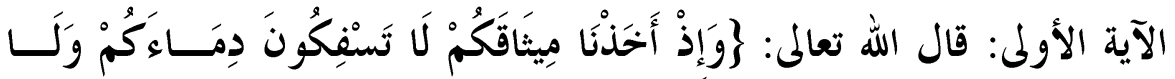

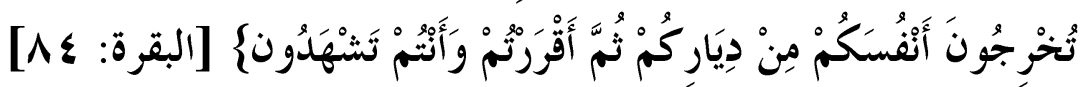

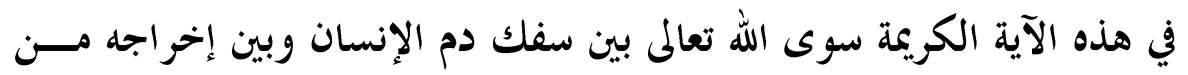

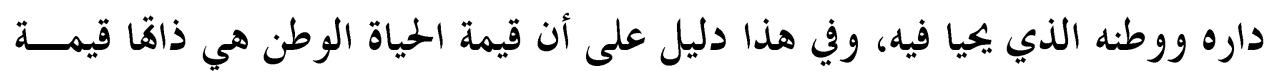

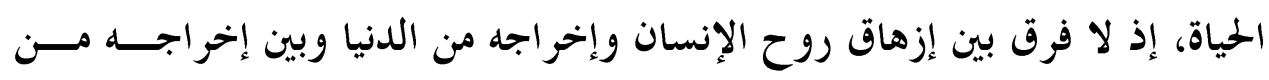

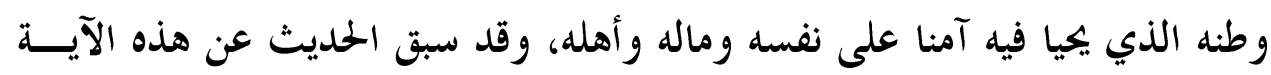
بالتفصيل في المبحث الثاني من هذا الفصل.

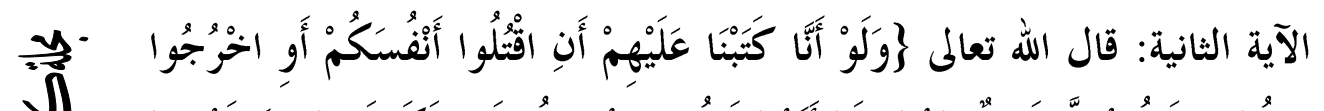

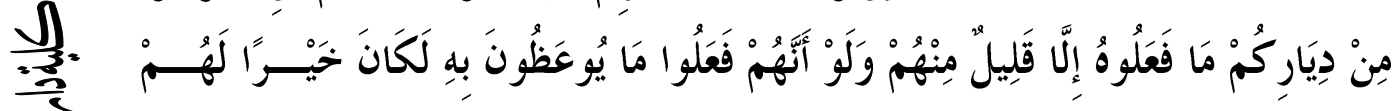

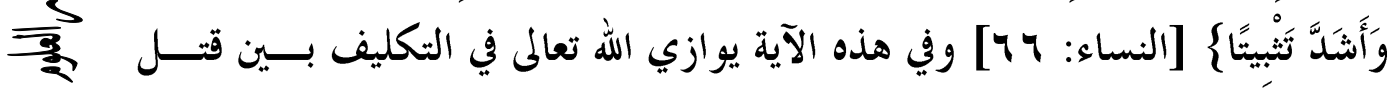
ए人। النفس والحروج من الوطن.

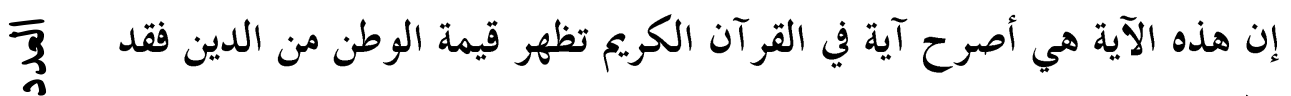

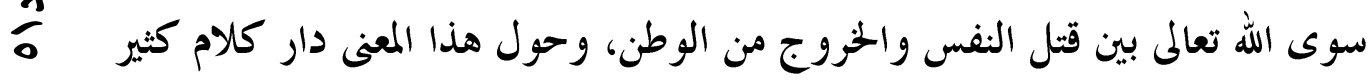
من المفسرين

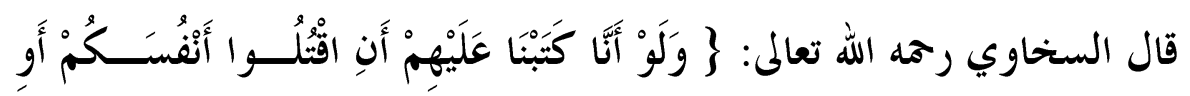

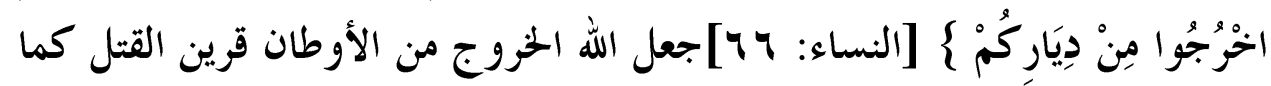

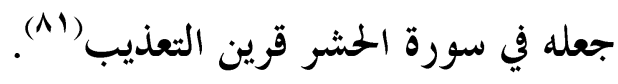

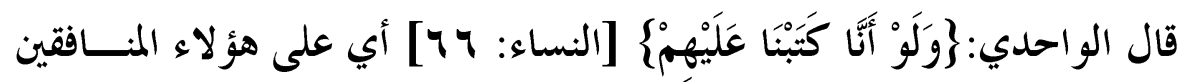

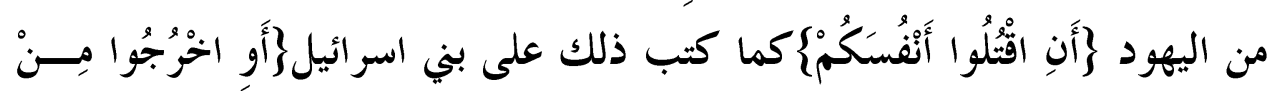

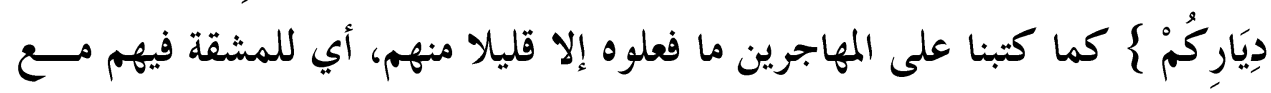

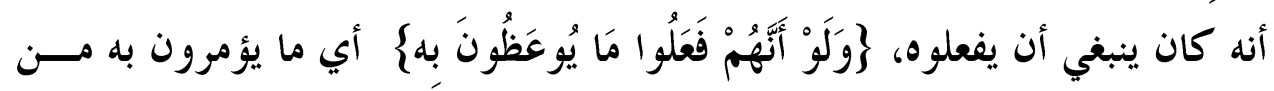

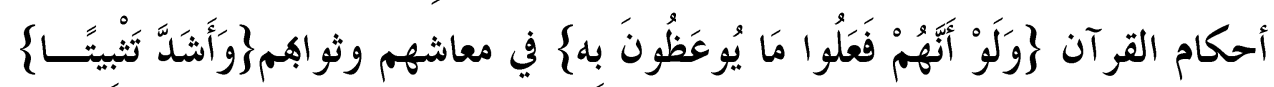
منهم لأنفسهم في الدين وتصديقا بأمر الله (AT). 


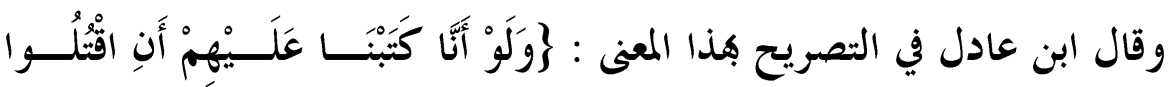

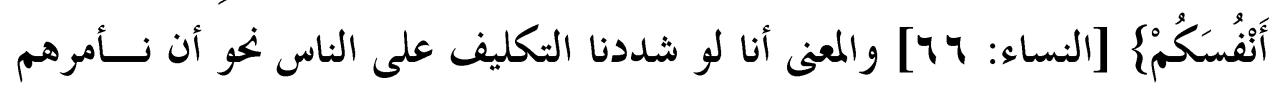

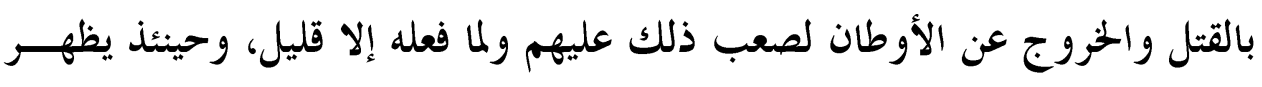
كفرهم فلم نفعل ذلك رحمة منا على عبادنا بل اكتفينا بتكليفهم في الأمور الســـهلة ولئل

$$
\text { فليقبلوها وليتر كوا التمرد (بهم). }
$$

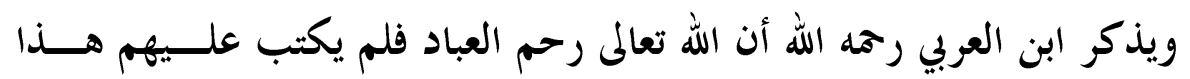

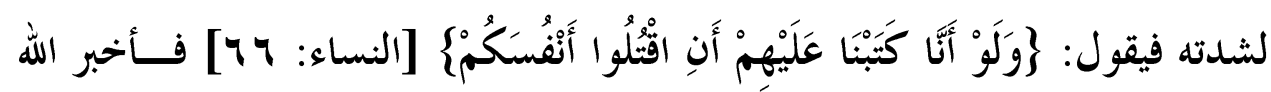

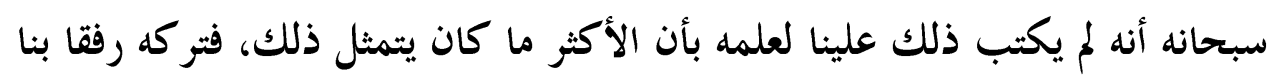

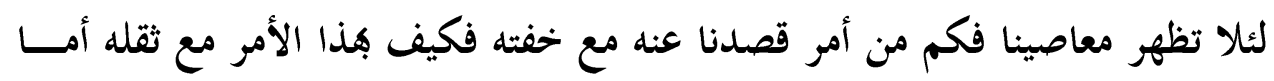

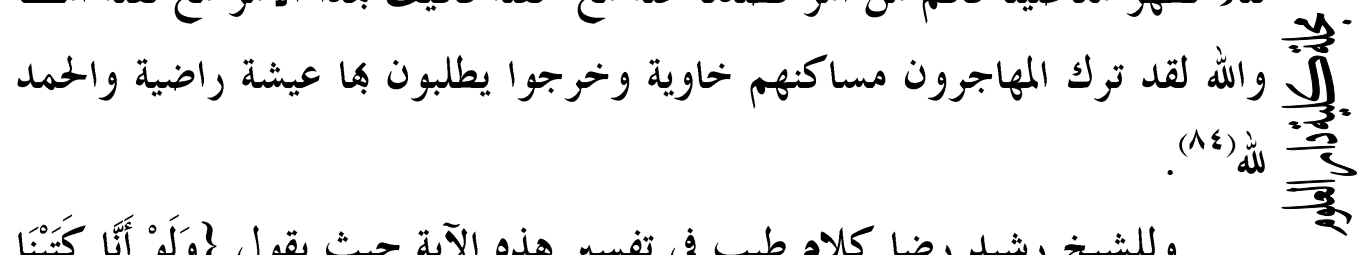

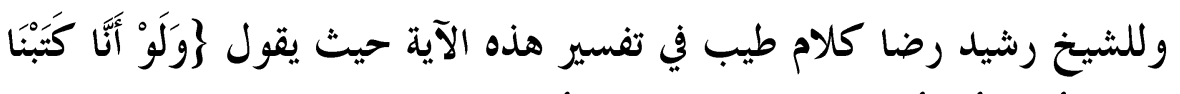

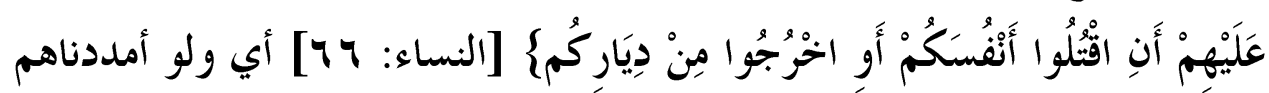

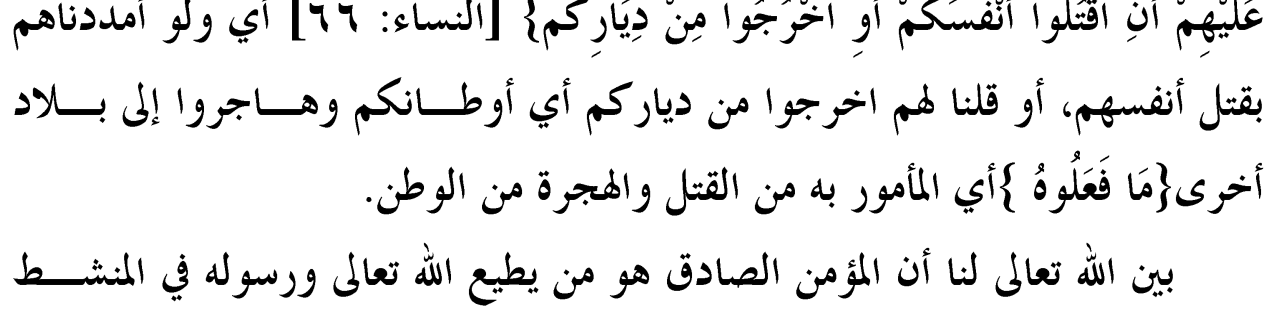

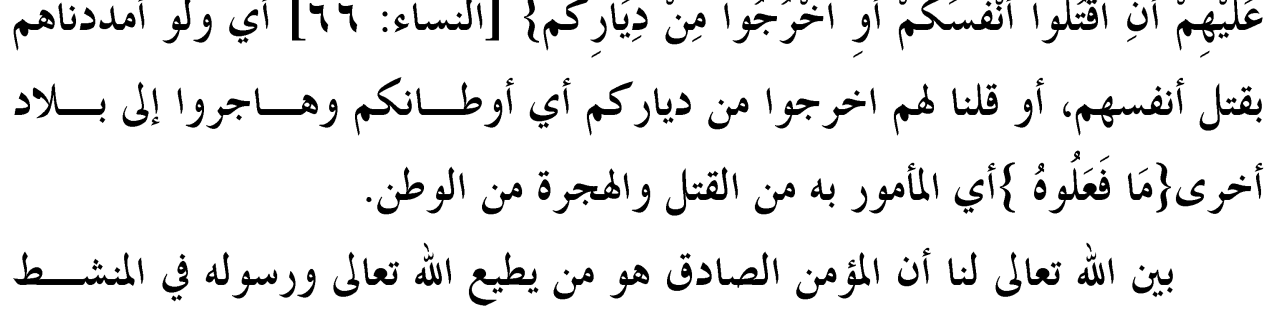
rNY

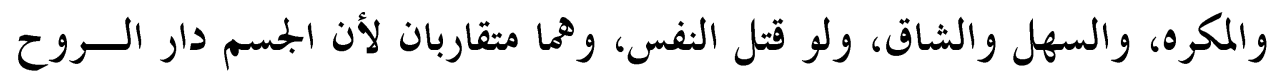

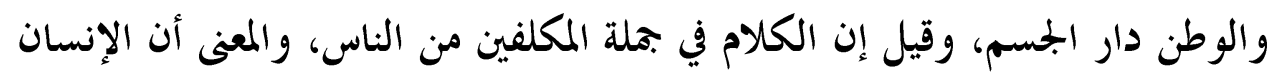

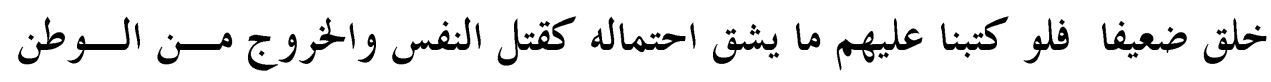

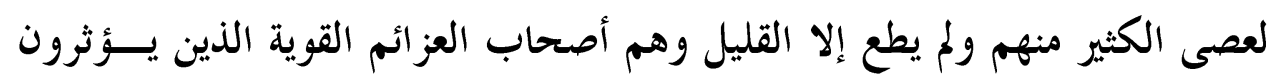
رضوان الله على حظوظهم وشهو اتهم (10).

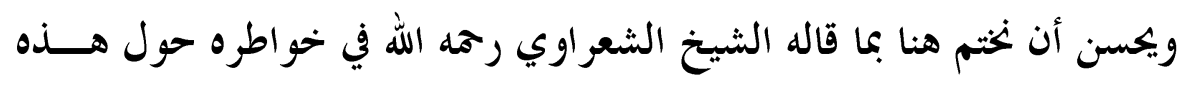

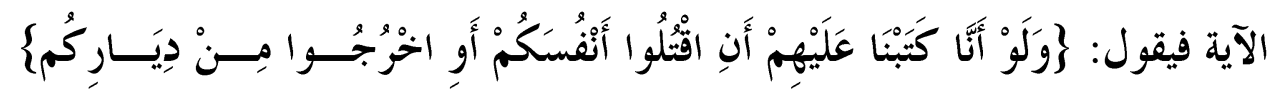


[النساء: 7 7] وهنا يساوي الحق بين الأمر بقتل النفس والإخراج من الدار فالقتل خروج الروح من الجمسد بقوة قسرية غير الموت الطبيعي، والحروج من الديار هـــو الترحيل القسري بقوة قسرية خارج الأرض التي يعيش فيها الإنسان، إذن فعمليــة القتل قرينة لعملية الإخراج من الديار فساعة يقتل الإنسان فهو يتألم، و كلاهما شاق

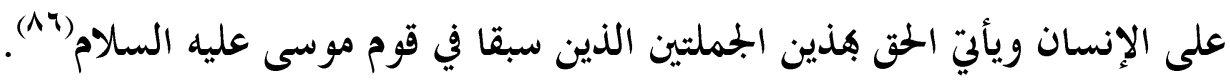

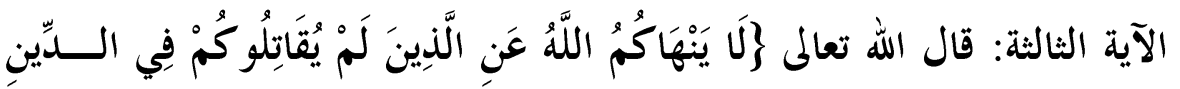

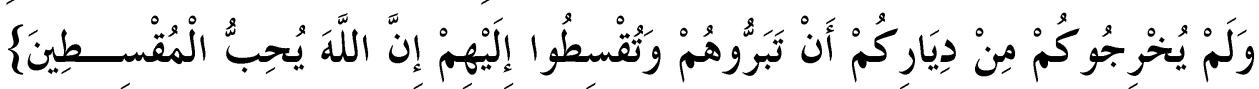

势 ] 1 ] ففي هذه الآية أيضا سوى الله تعالى بين القتال في الدين بغية التضــييق علــى المسلم في إقامة شعائره الدينية وبين الإخراج من الوطن الذي يجيا فيه آمنا مطمئنا.

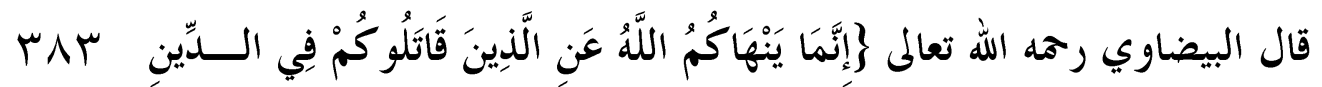

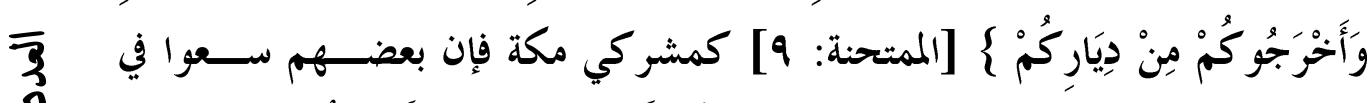

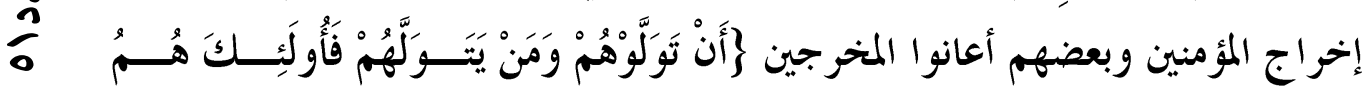

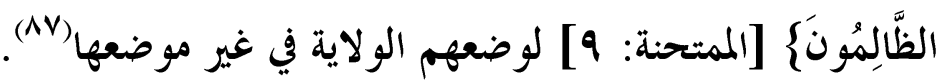

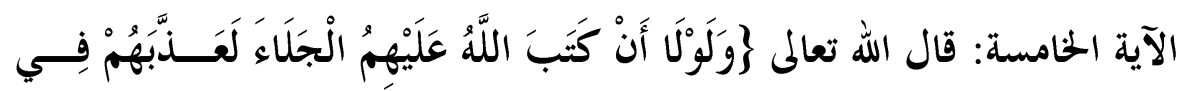

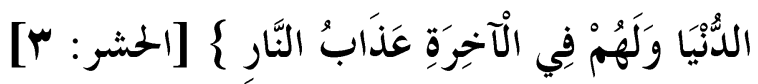
هذه الآية الكريمة من الآيات الصريحة التي تظهر قيمة الوطن وتعلي من قدره، وتجعله قرينا للأمن النفسي وراحة البال وهدوء الحال، وأن الحرمان من الوطن هـــــ العذاب ذاته فهو بديل عنه في هذه الآية الكريمة السابقة، وهو عقوبة إلهية مــن الله تعالى الذي جعل لليهود إحدى عقوبتين: الجلاء عن الوطن أو العــــاب في الــدنيا، واختار لهم العقوبة الأولى رحة بهم وإلى هذه المعالي التجهت كلمة المفسرين جلهم وفي السطور الآتية بيان لأقوال بعضهم: 


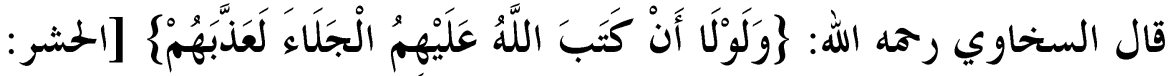

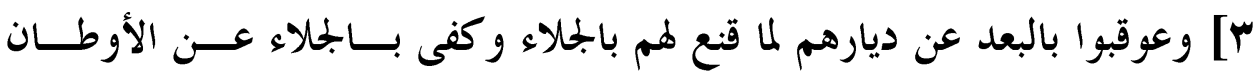
عقوبة(1^). (1).

وقال ابن عجيبة في بحره المديد:

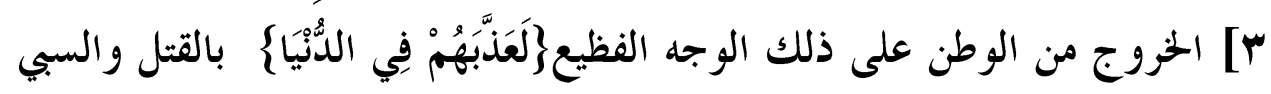
كما فعل ببني قريظة(1). الحزوج من الرطن على

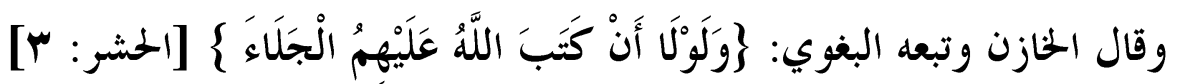

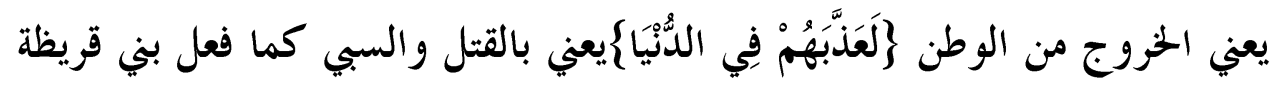

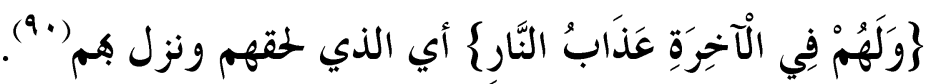

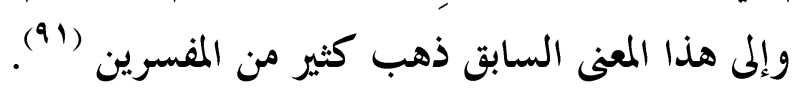

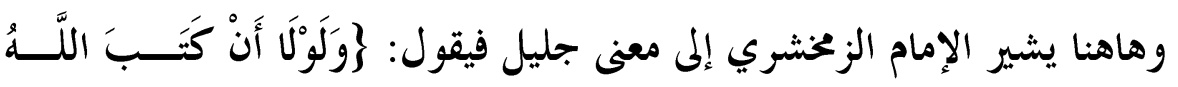

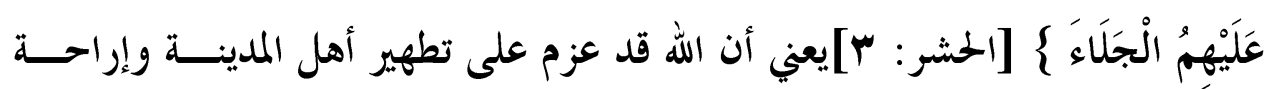

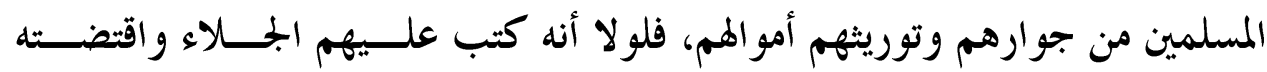

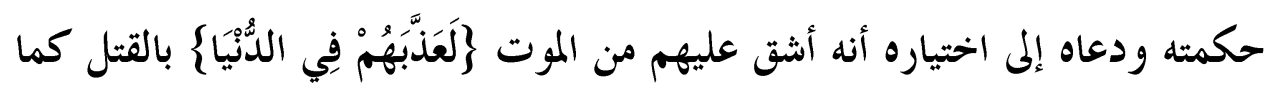

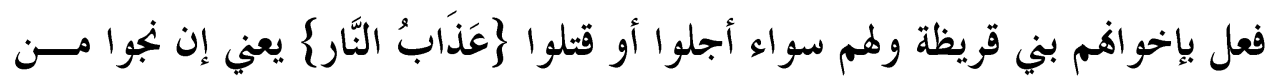
H人

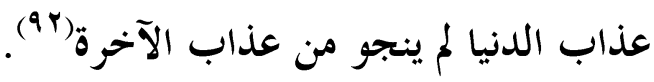
وقال صاحب التحرير والتنوير: والمراد بالتعذيب الألم الخسوس بالأبدان بالقتل

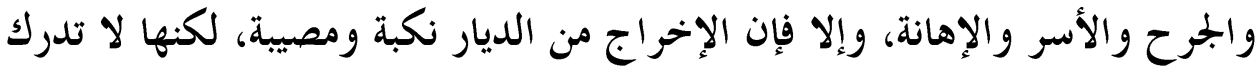

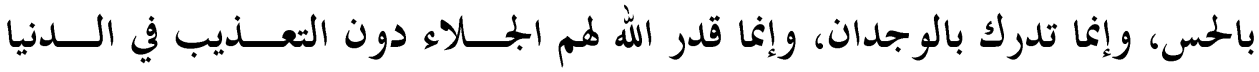

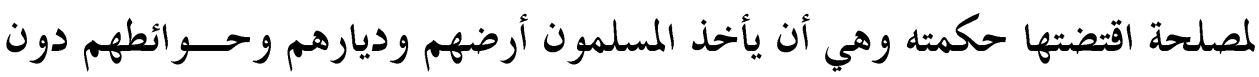

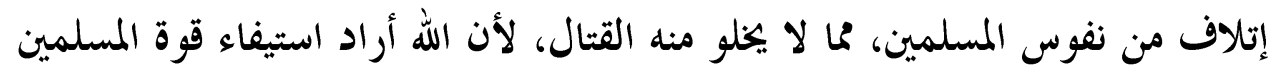

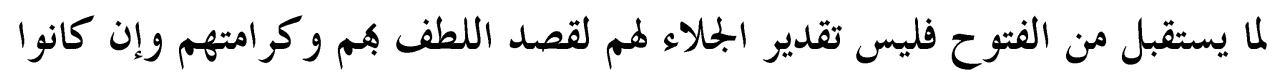

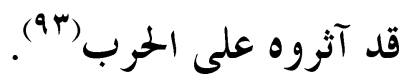


فانظر كيف اتفقت كلمة المفسرين على أن الحُروج من الوطن يساوي القتــل أو العذاب، وفي هذا إشارة إلى قيمة الوطن ومكانته من الدين. المبحث السابع: هجرة الوطن بين الثواب والعقاب

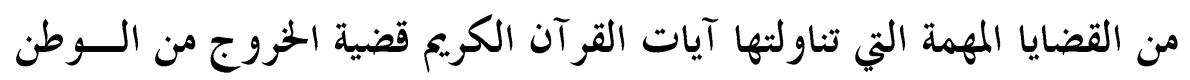
على سبيل الهجرة منه، وهل هذا في كل وجه محمود أو مذموم، فالذي يطالع آيــات الكتاب الكريم يجد أن القر آن الكريم قد فرق بين الهجرة الخمودة التي هي في ســبيل الله وتقديم حقه على حق كل من هو دونه حتى ولو كان هذا الحتق هو حق الــوطن،

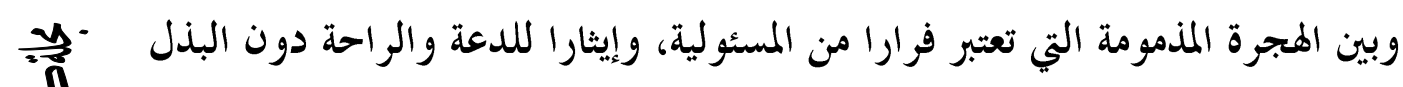

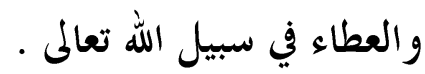
فهناك فارق كبير بين هجرة هي في نفسها هروب من الأذى، وتبـــلا لمكـــان

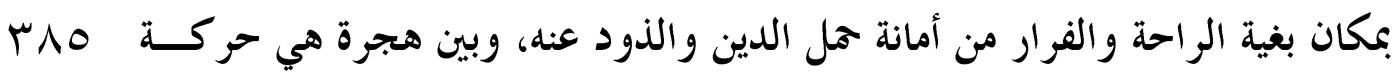

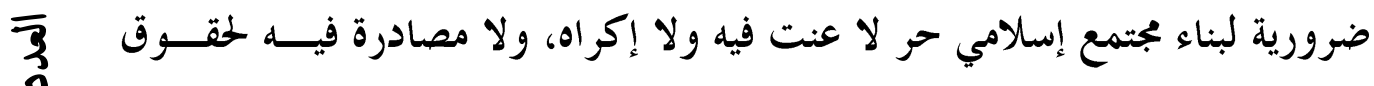

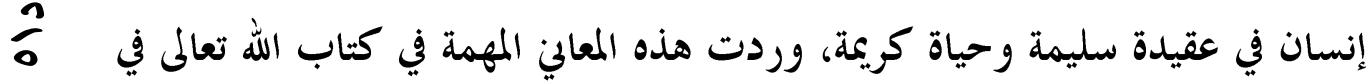
بيان الهجرة الخمودة واستحقاق أصحابها الثواب العظيم عليها في ثلاث آيات كريمة وهي:

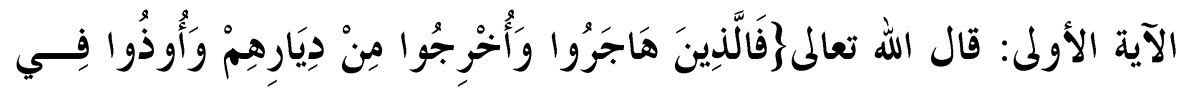

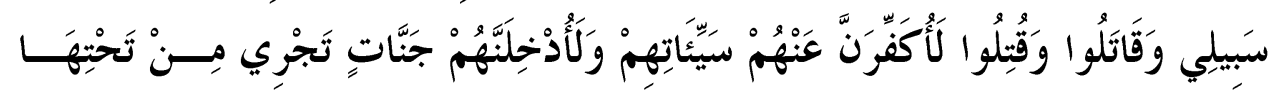

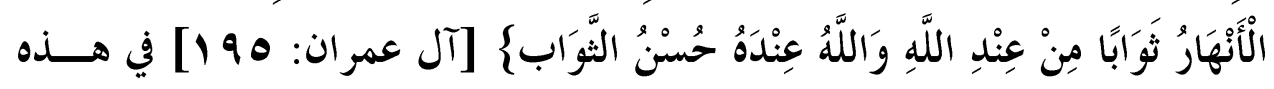
الآية الكريمة بين الله تعالم أن مكانة الذي يهجر وطنه وموضع ولادته ومرعى صباه، ويخر من داره بعد إيذائه في سبيله تعالم فارا بدينه بعد قتل وقتـــال، لا ثـــك أنـــهـ مستحق لثواب الله تعالم الذي هو تكفير الذنوب والخطايا ودخول الجنــات الــتي أعدها الله تعالى لعباده الصالحين. 
قال ابن الجوزي: \}فَالَّذِينَ هَاجَرُواُ\{ [ آل عمران: 190 1

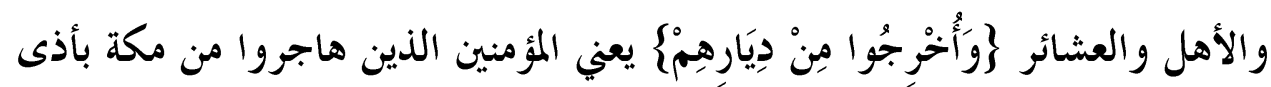

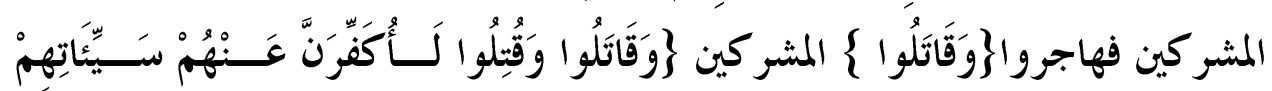

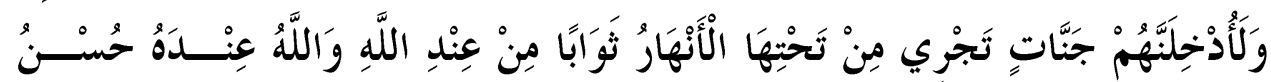

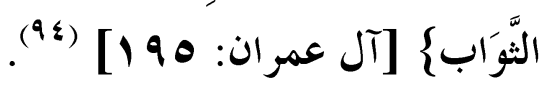

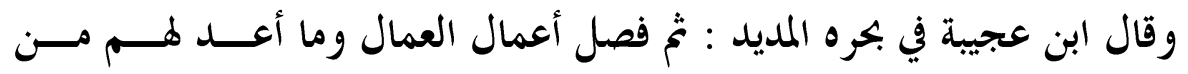

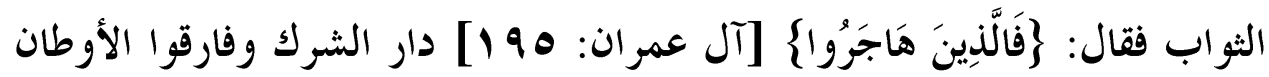

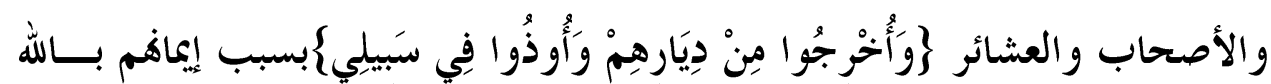

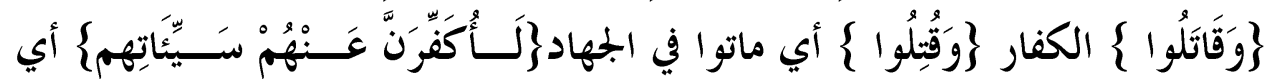

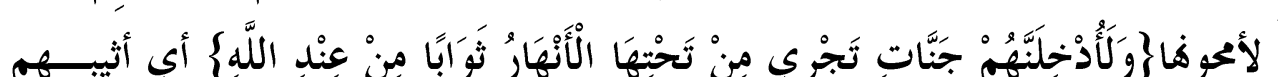

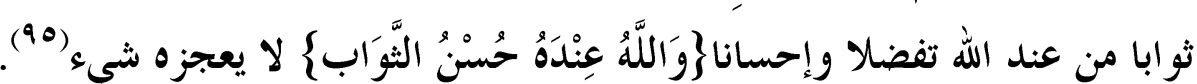

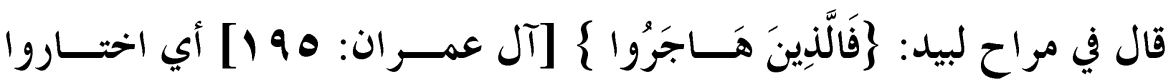

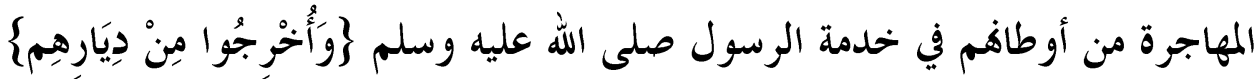

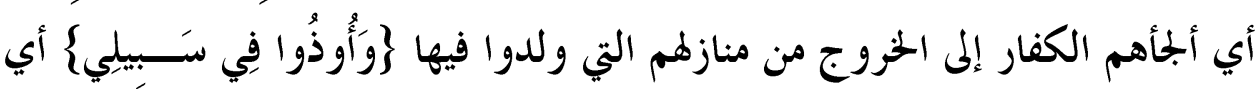

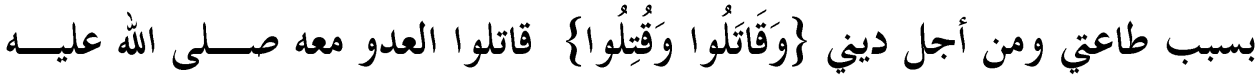

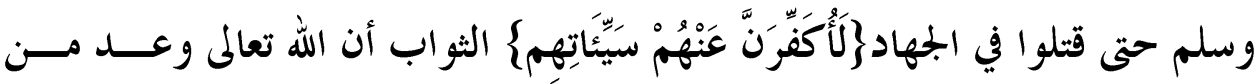
فعل ذلك بأمور ثلاثة أولها: محو السيئات وغفران الذنوب وثانيها: إعطاء الثــــواب العظيم وهو دخول الجنان وثالثها: كون الثواب مقرونا بالتعظيم (ج9).

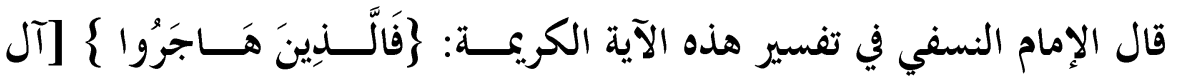
عمران: هو 9 ] مبتدأ وهو تفصيل لعمل العامل منهم على سبيل التعظيم له، كأنــه. قال: فالذين عملوا هذه الأعمال السنية الفائقة وهي المهاجرة من أوطاكم فارين إلى

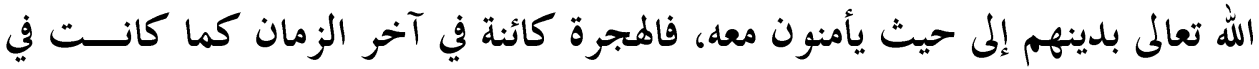

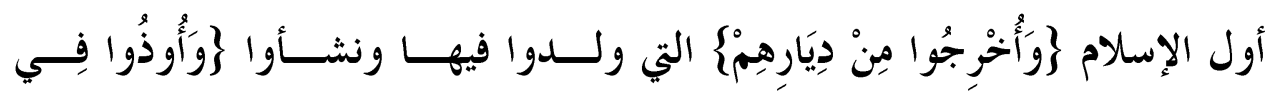




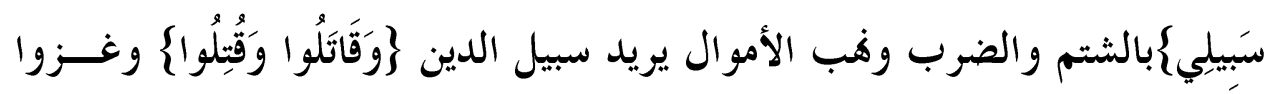

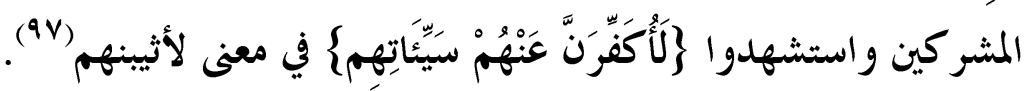

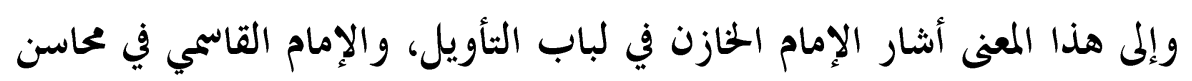

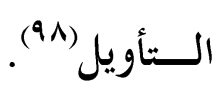

فأنت راء أنه ما من مفسر مما ذكرت إلا ونص على أن الفارق بين الصــفين

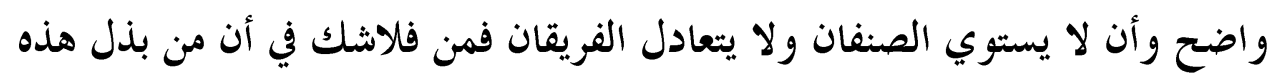

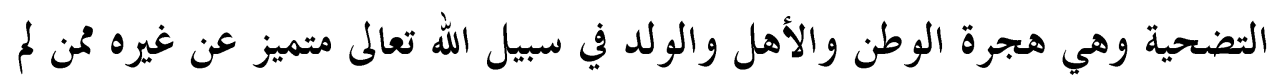

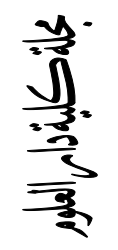
يوفق إلى هذا.

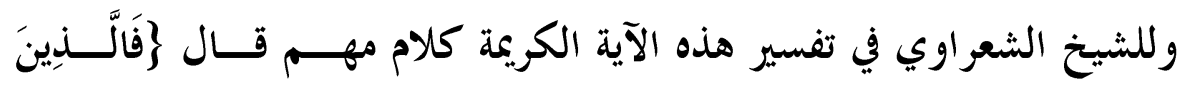

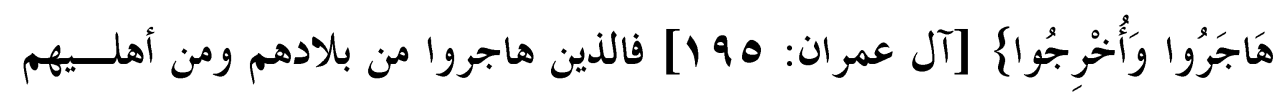

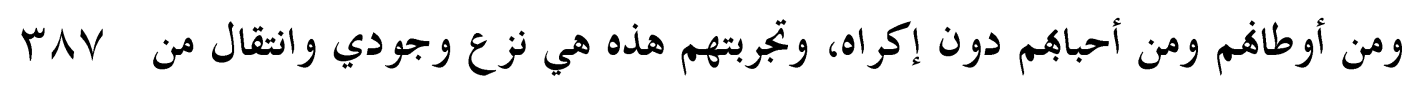

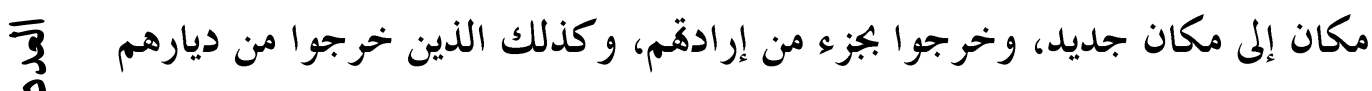

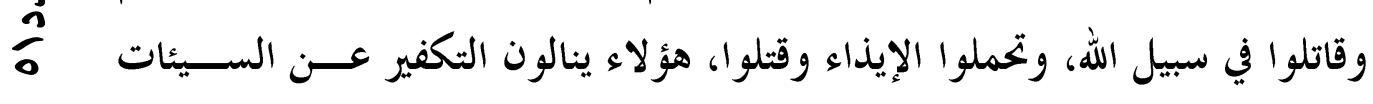

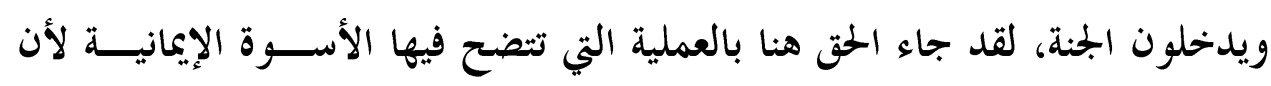

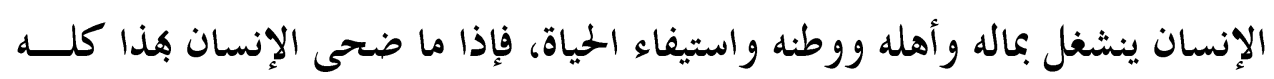

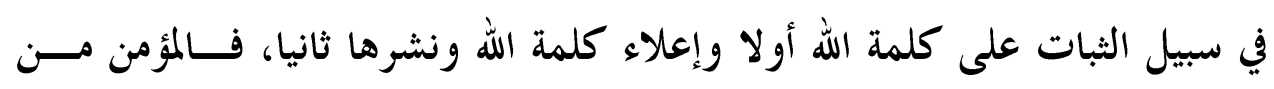

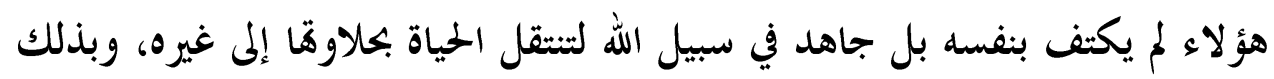

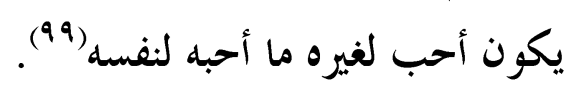

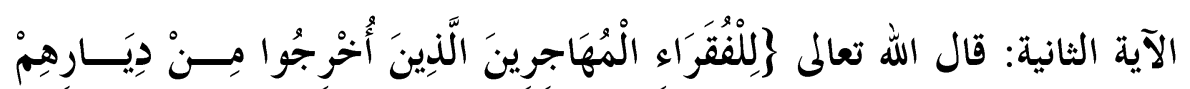

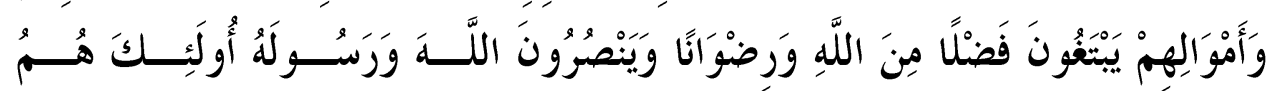

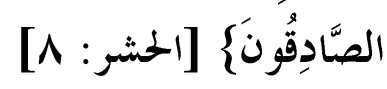


مدح الله تعالى في هذه الآية الكريمة من خرج مهاجرا إلى الله تعالى، فقيرا إليــه. مستعينا به فارا بدينه إليه تعالم، والمقصود هنا المهاجرين الــذين تركـــــا ديـــارهم وأمو الهم ويصدق على من هو في مثل حالهم ما أعده الله تعالمى لهم . قال ابن عطية في بيان هذا: ثم وصفهم الله تعالم بالصفة التي تقتضي فقــــــمه، وتوجب الإشفاق عليهم، وهي إخراجهم من ديارهم وأموالهم، وجميع المهاجرين إما

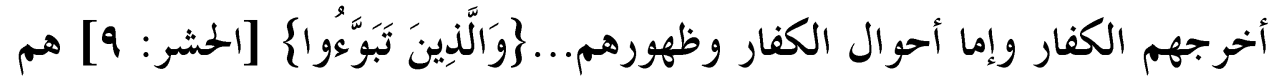

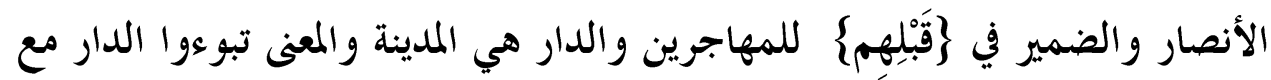
الإيمان معا."(1).

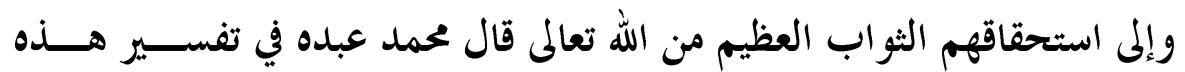

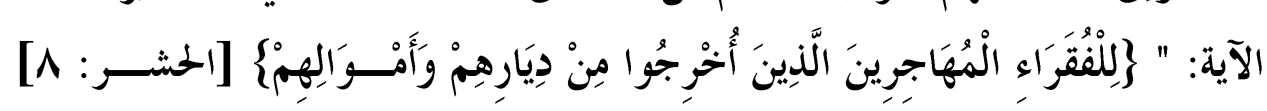

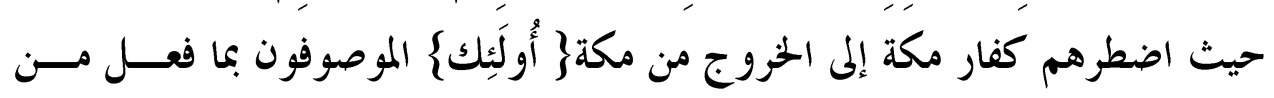

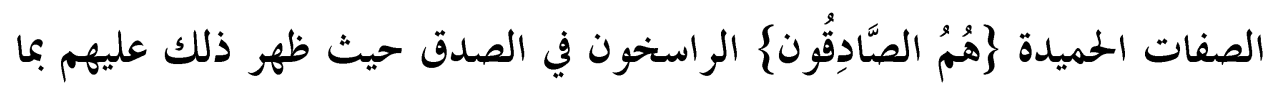
فعلوا من مفارقة الأوطان والأهل والولدان...ثم قال: فالذين يستحقون من المواهب

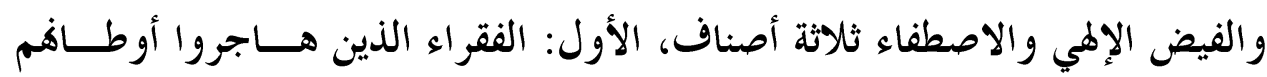
وتر كوا ديارهم وعشائرهم طلبا لصلاح قلوبهم وأسرارهم (1 +1). $\overline{3}$

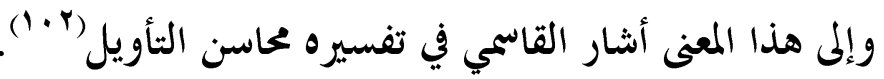

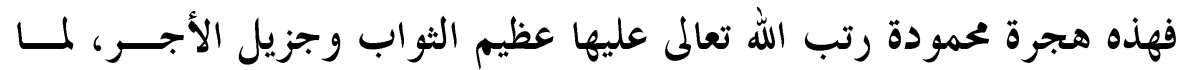
للوطن من مكانة في قلب الإنسان، ومع هذا كله آثر رضا الله تعالم وفر بدينه الذي لم يتمكن من إقامته في وطنه، فاستأهل بذلك الثواب الجزيل من الله تعالى.

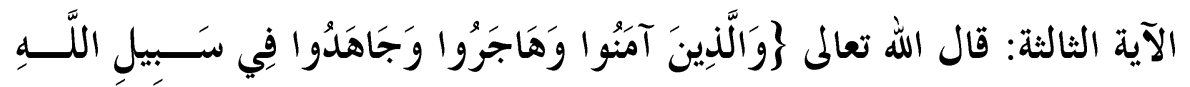

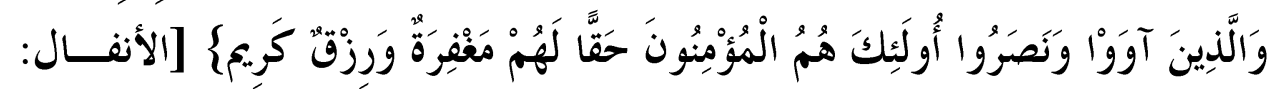
ع[Vقد وصف الله تعالم في هذه الآية الكريمة هذا الصنف من الناس بأفم المؤمنون

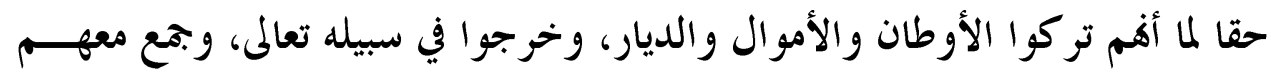


من أواهم ونصرهم لما لدين الله تعالم من مكانه تعلو كل مكانه، ومتزله تقدم كــل منزلة.

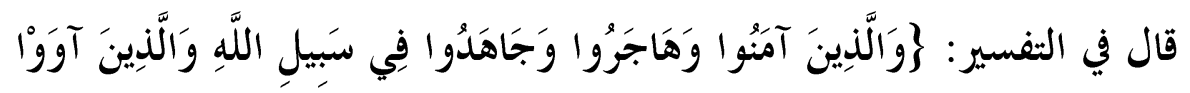
وَنَصَرُواُ [الأنفال: \& \&]فالله تعالم ذكرهم أولا ليبين حكمهم، وهو إكرام بعضهم بعضا، ثم ذكرهم هاهنا لبيان تعظيم شأفم وعلو درجتهم، وأثنى عليهم مـــن ثلاثـــة أوجه: وهي وصفهم بكوفم محقين محققين في طريق الدين لأنه من لم يكن محقا دينه لم

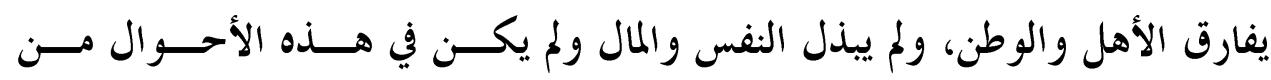

rᄉ وخرج من وطنه.

产

فانظر كيف أخذ هذا المفسر من بذل الوطن في سبيل الله تعالم دلـــلا علــى أحقية الدين الذي يعتنقه الإنسان وإخلاصه فيه، لأنه لو لم يكن كذلك لما بذل ماله،

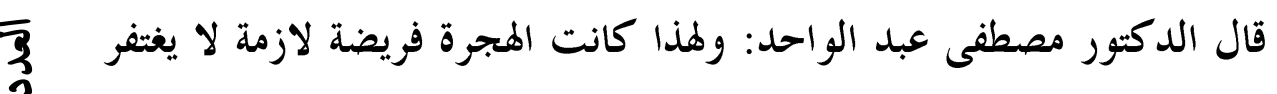

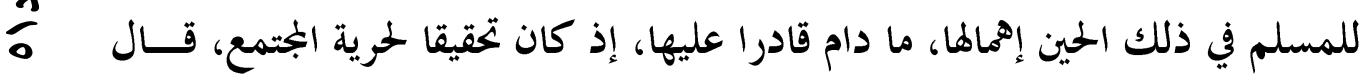

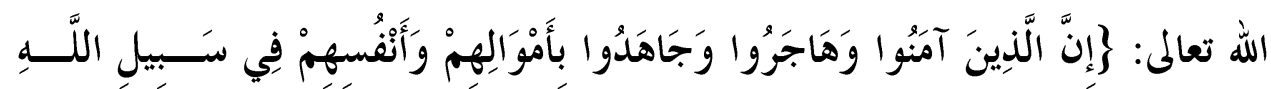

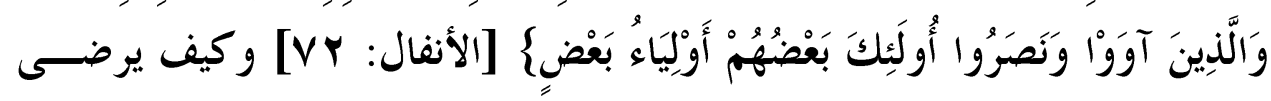
المسلم لنفسه بالفتنة والقهر، وكيف لا ينجو بعقيدته إلى أفق حر لا يؤذي فيسـه ولا يكره، إنه حينئذ يظلم نفسه وعقيدثه، ويلقي بيده إلى التهلكة، وذلك يعزله عن دينه ويخر جه عن حقيقته.

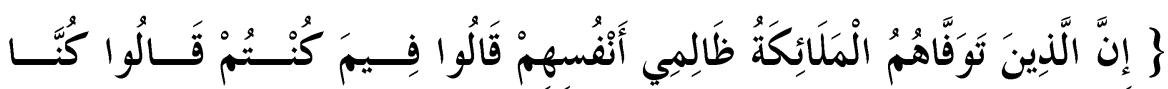

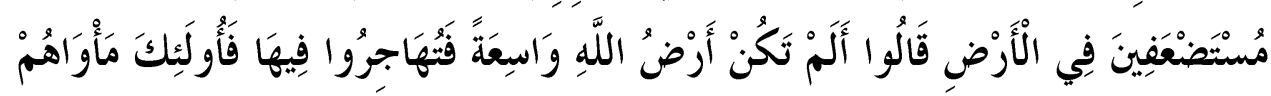

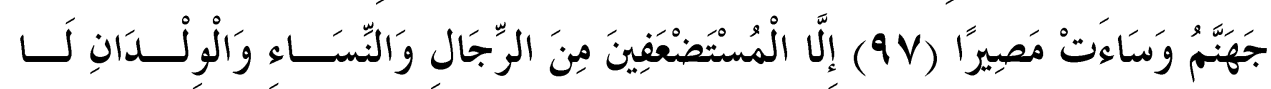

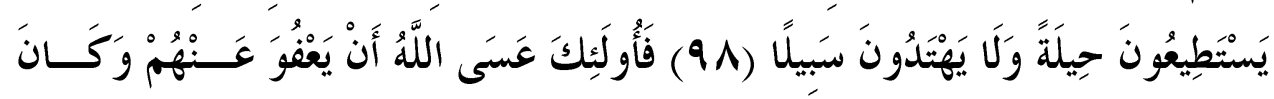

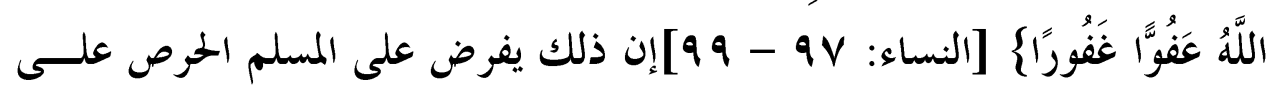


نيل حريته، والسعي لفكاك نفسه من العبودية لغير الله، والنجاة من قبضة الكفــر، وأرض الله واسعة، فلن يعدم أفقا حرا ينجيه من البأس ويقيه الفتنة والاضطهاد، ولن ولن يضطر المسلم أبدا أن يقبل الدنية، أو يرضى بالهوان ما دامت في آفاق الأرض سعة،

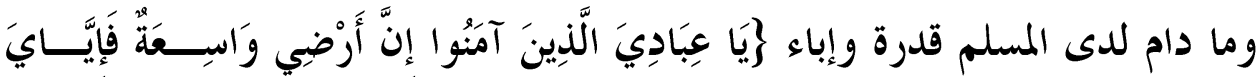

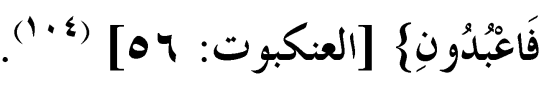

هذه بعض إثارات قر آنية تبين مكانة الوطن من الدين ومتى تكون هجرتسـه ــ على مكانته الكبيرة - محمودة يستحقى صاحبها الثواب العظيم.

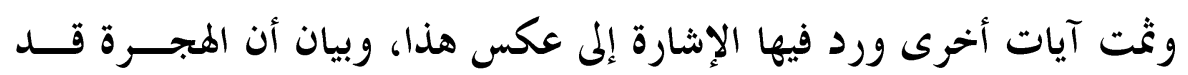

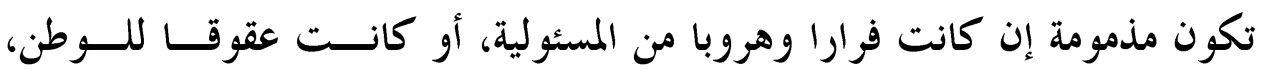

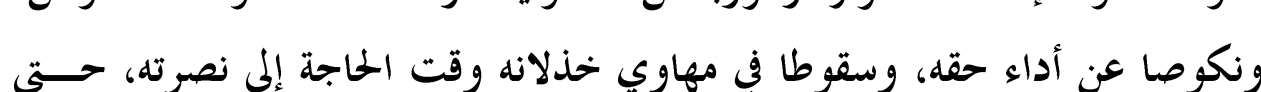

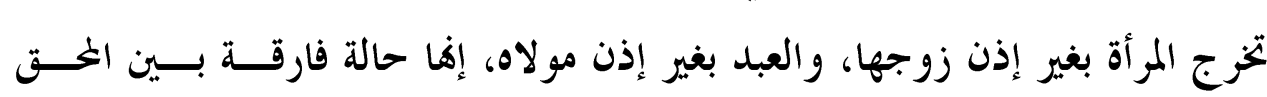
告 .

ورد هذا المعنى في آية واحدة من كتاب الله تعالم هي قول الله تعالى : رُألَمْ تَرَ

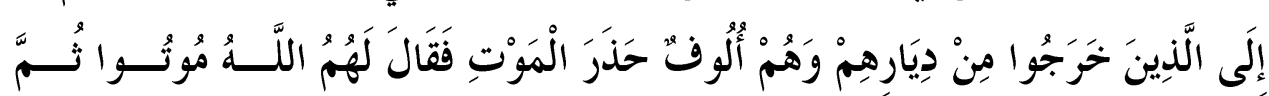

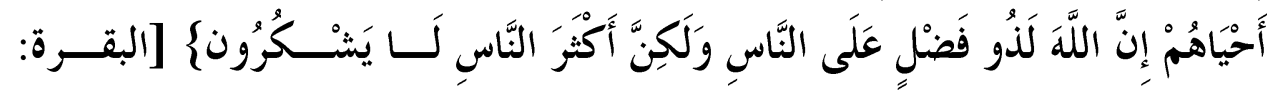
$\overline{3}$
3
0

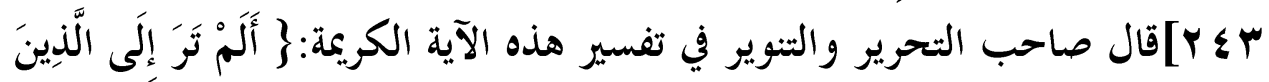

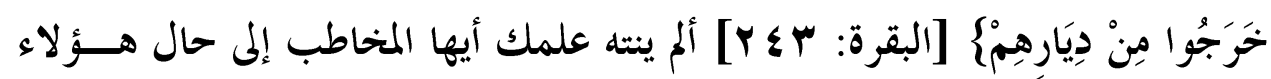

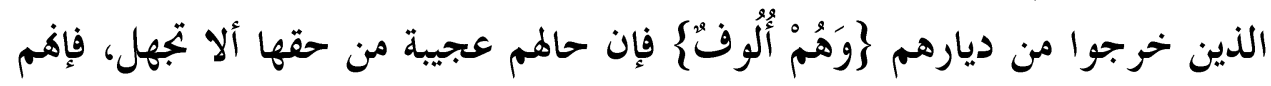

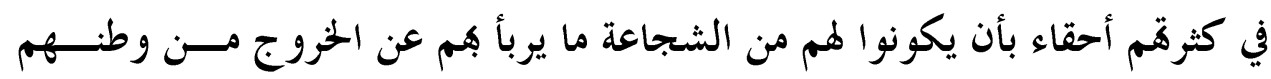

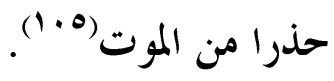

وانظر إلى دقة التعبيز القرآي في عطف الأمر بالموت على الخروج من الــديار بالفاء الدالة على اتصال الهلاك بالفرار من العدو، وإلى عطفه الاختيار بإحيائهم بثم 
الدالة على تراخي ذلك وتأخره، ولأن الأمة إذا شعرت بعدم البلاء بعد وقوعه بهــــا

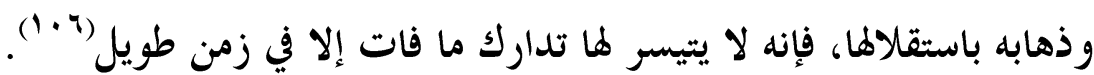

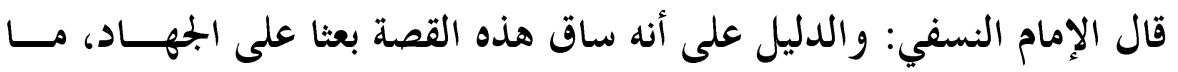

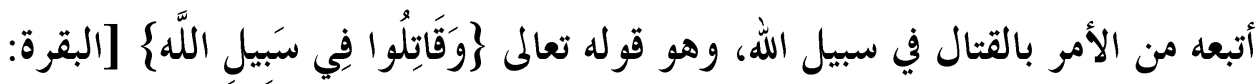

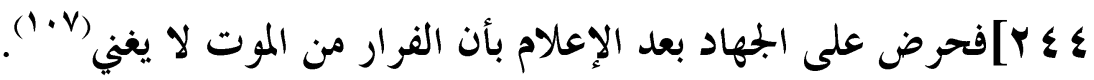
المبحث الثامن: مشروعية الدفاع عن الوطن من الأمور المهمة التي تناولتها آيات القر آن الكريم في الحـــديث عــن قضـــية

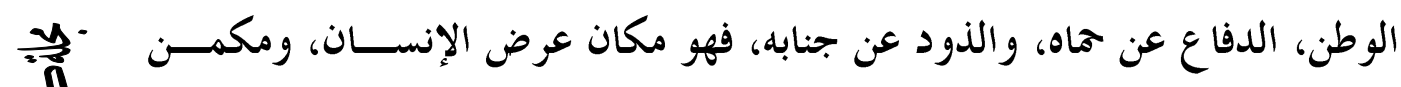
齐 شرفه، وموئل أمله، فإن الإنسان على أرضه يحيا، وفي نعيمه وخيراته يتقلب، ومـــن مائه يرتوي، يفترش أرضه، ويلتحف سماءه، عزه من عزه ، وشرفه من شرفه.

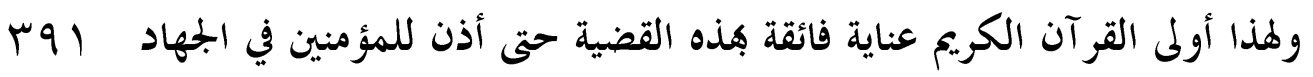

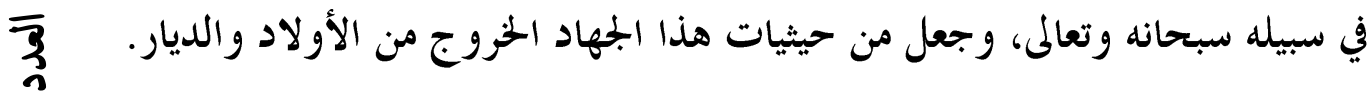
وقد تناولت آيات القر آن الكريم التي ورد فيها الحديث عن هذه القضية، وهي مشروعية الدفاع عن الوطن تناولت الحجة التي تدفع الإنسان إلى التضحية بـــالنفس و النفيس في سبيل العز لوطنه، والسلامة لأرضه وعر أله.

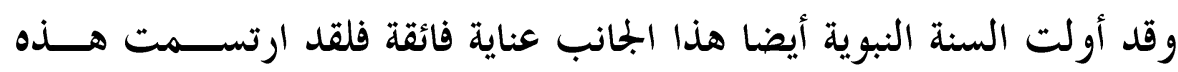
المبادئ في شخص الرسول صلى اله عليه وسلم، وصارت هديا له، وسمتا لا يفارقه،

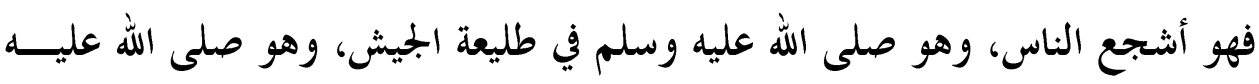
وسلم من كان الصحابة رضي الله تعالى عنهم يتوقون به الأعداء إذا حي الوطيس. يقول الدكتور محمد المسير في وصف حاله صلي الله عليه وسلم: من منطلـــــ أن الرسول صلى الله عليه وسلم هو الإمام والحاكم للمسلمين كان يقظا في حراسة

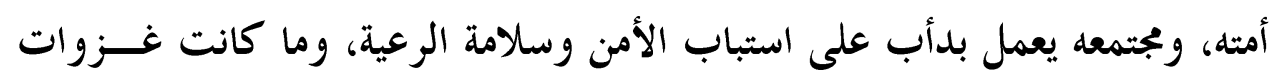


رسول الله إلا لونا من ألوان الدفاع عن الدين والجزتمع وماية الناس، وأمنا وتثبيتــــا للاستقرار و السلام.

وفي أوقات السلم وأثناء الليل كان صلى الله عليه وسلم يتفقد رعيته، ويحدثنا أنس بن مالك رضي الله عنه عن موقف فذ من مواقف الحياة النبوية الشريفة، فيقول كما في صحيح مسلم: كان رسول الله صلى الله عليه وسلم أحسن الناس، وكـــان أجود الناس، وكان أشجع الناس، ولقد فزع أهل المدينة ذات ليلة فانطلق ناس قبل الصوت فتلقاهم رسول الله صلى الله عليه وسلم راجعا، وقد ســـقهم إلى الصـــوت وهو على فرس أبي طلحة عري في عنقه سبق، وهو يقول لن تراعوا، قال: وجــــناه بحرا، أو إنه لبحر، و كان فرسا يبطأ.

وفي هذا الحديث الثريف نجد النبي صلي الله عليه وسلم خرج قبــل النـــاس

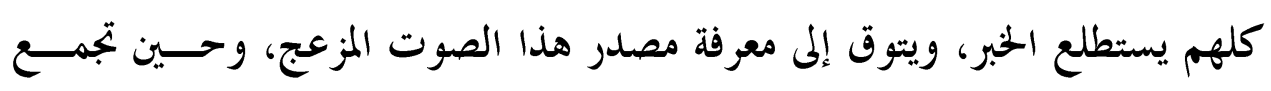
الناس وأرادوا الذهاب لكشف حال الموقف، تلقاهم الرسول صلى الله عليه وســلم راجعا مؤ كدا لهم استباب الأمن، مبشرا لهم بالهدوء و السلام.

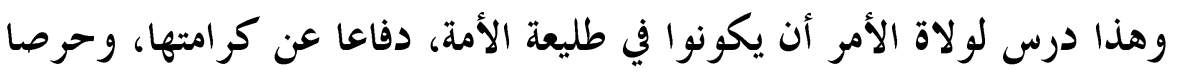
على سلامة أبنائها وذودا عن مقدساها، ولا بقاء لهم إلا بقدر ما يبذلون من حسـرص وتضحيات، وليست الولاية مغنما، وإنما هو تكليف وتبعات، يتحملها أكفاء الرجال

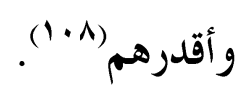

ولعل من يطالع أقوال المفسرين في تفسير آيات كتاب الله تعالى من الآيات التي عنيت ببيان مشروعية الدفاع عن الوطن، يدرك ما لهذه القضية من أهمية قصــوى في التشريع الإسالامي. وفي السطور الآتية نقف مع الآيات الواردة في هذا الشأن. 


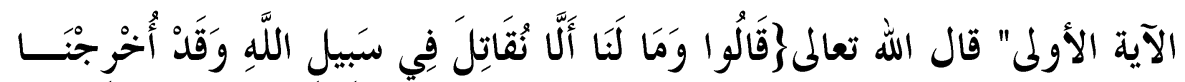

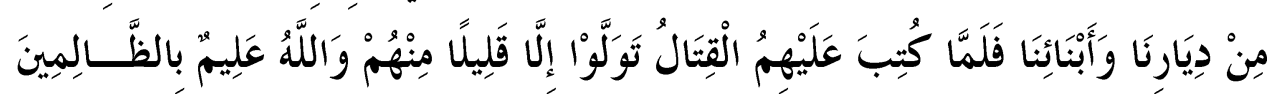

$$
\text { \{ }
$$

في هذه الآية الكريمة يورد المولى عز وجل على لسان الملأ من بــني اســرائيل

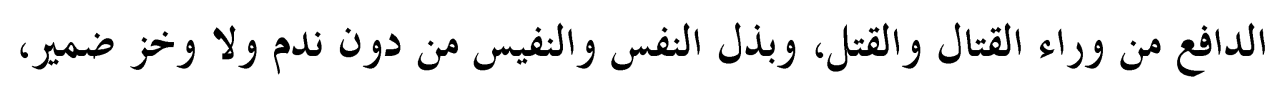
وهذا الدافع هو الحروج من الديار والأبناء.

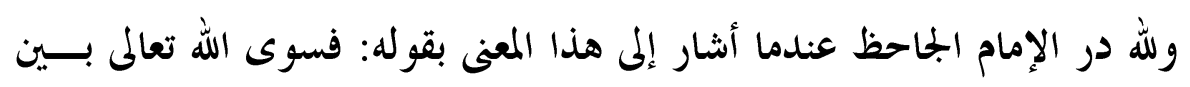

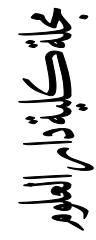

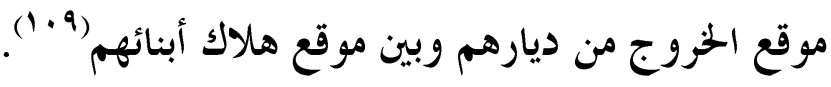
وإلى هذا المعنى أشار جل المفسرين.

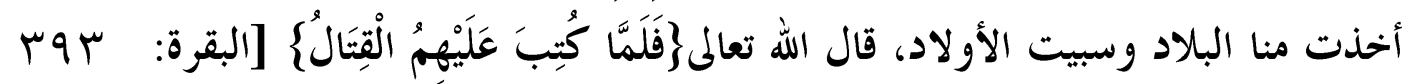

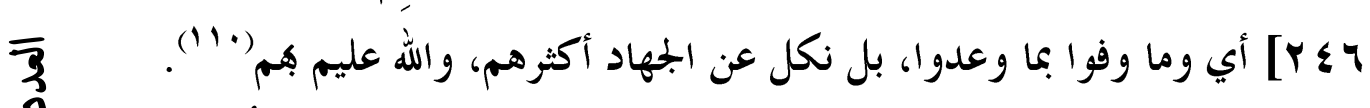

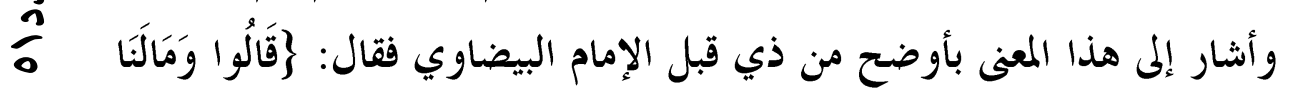

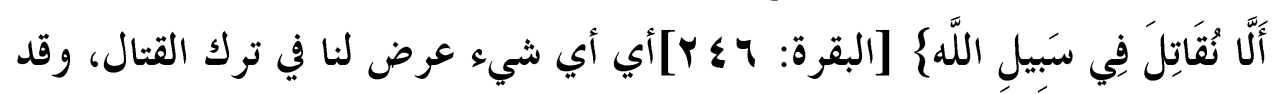

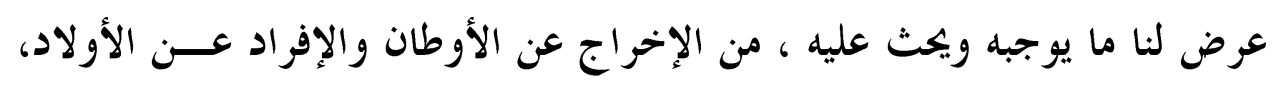

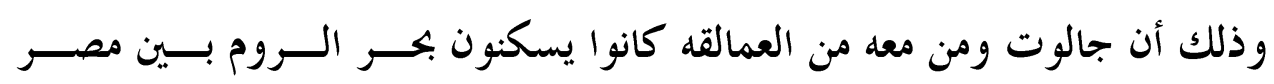

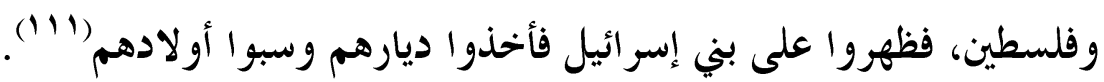

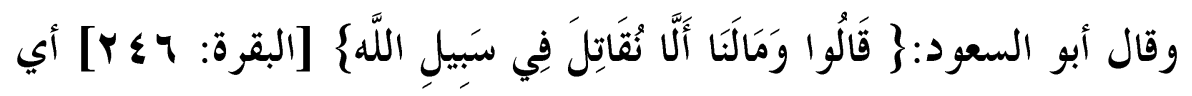

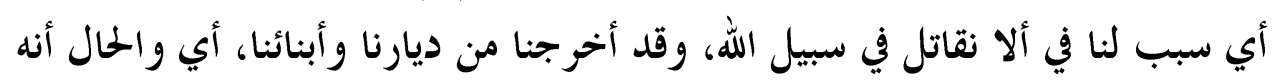

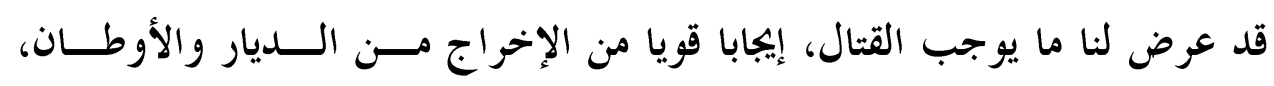

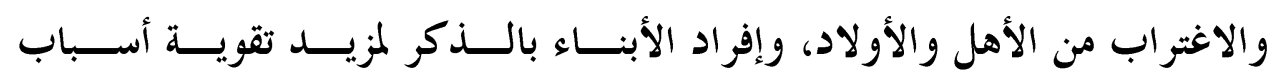

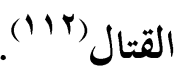




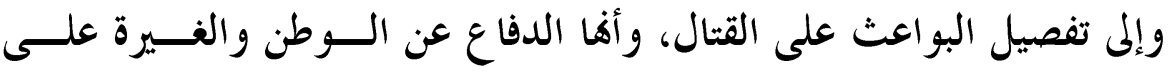
الأولاد والأعراض، أنشار الإمام أبو زهرة في تفسيره بقوله: أجابوا نبيهم بأفم قدروا

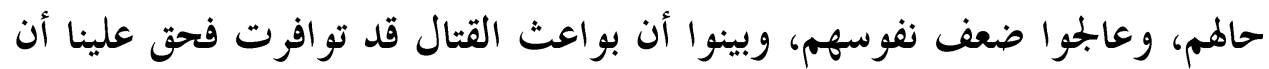

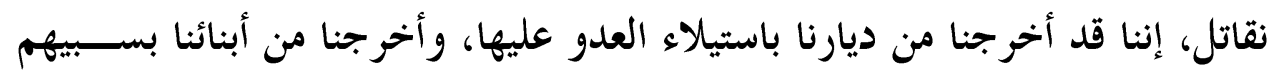

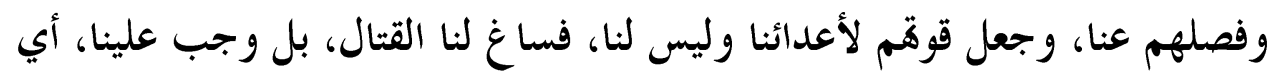

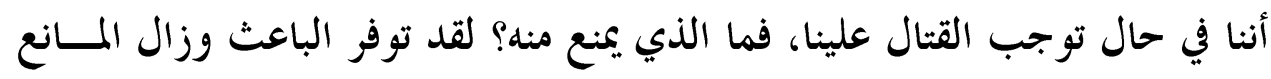

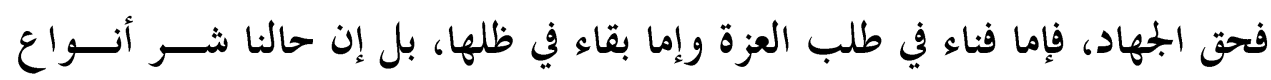

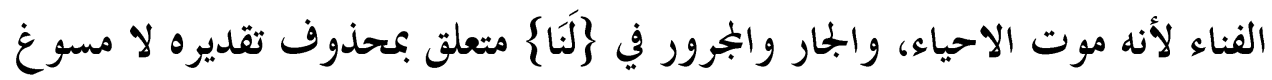

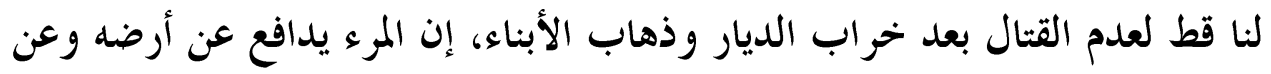

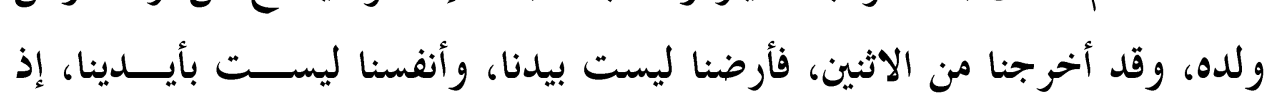

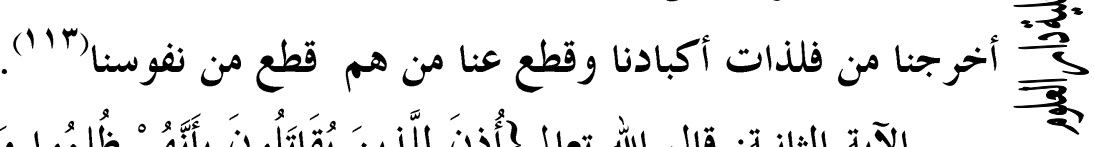

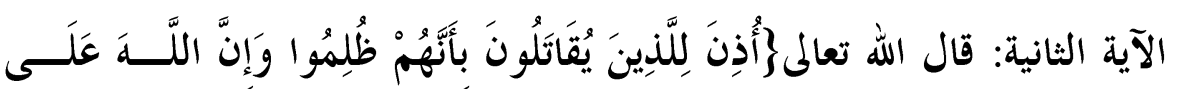

$$
\text { نَصْرِِمْ لَقَدِير }
$$

هذه الآية الكريمة تأذن للمؤمنين في الجهاد في سبيله تعالى وتشرعه لمم، لما أفم

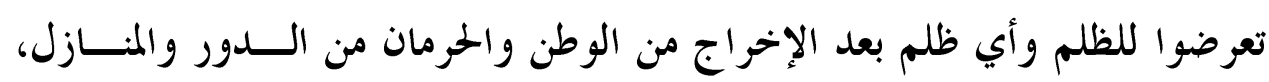

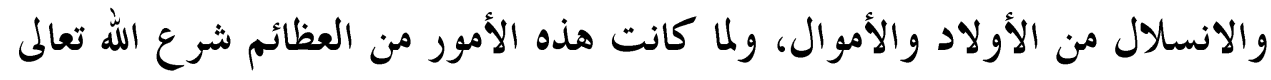

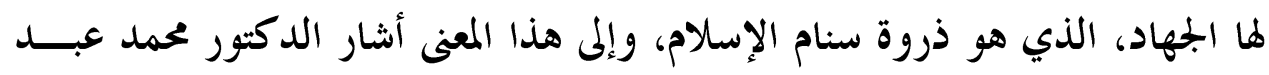

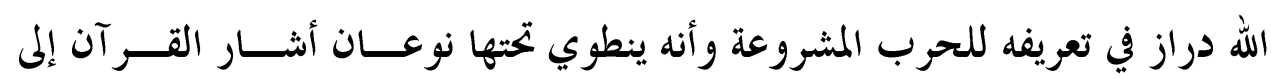

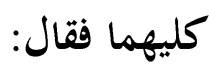
الأول : الدفاع عن النفس وفيه يقول الكتاب الجيد" أذن للذين يقاتلون بأفم

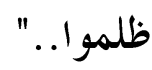

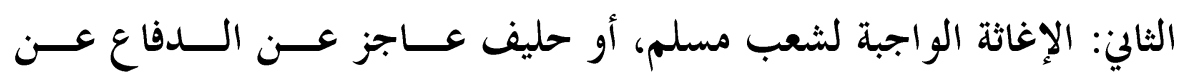

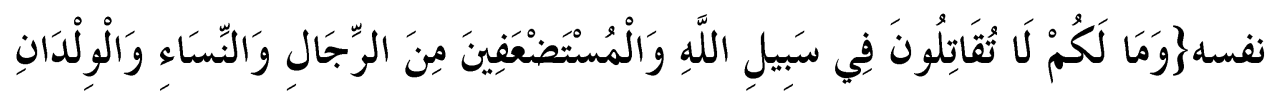




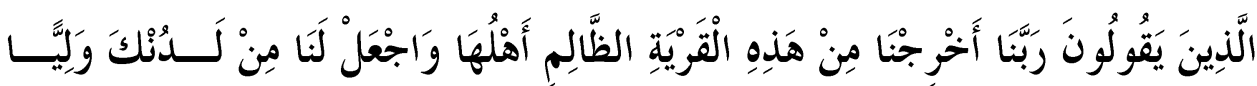

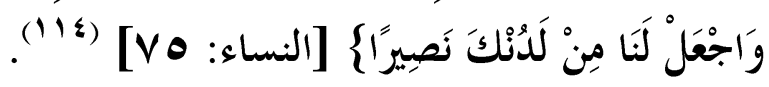

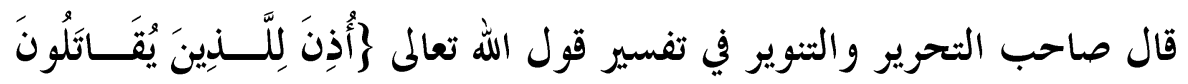

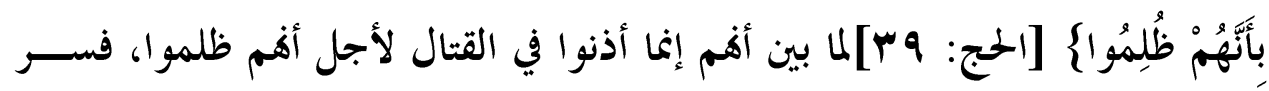

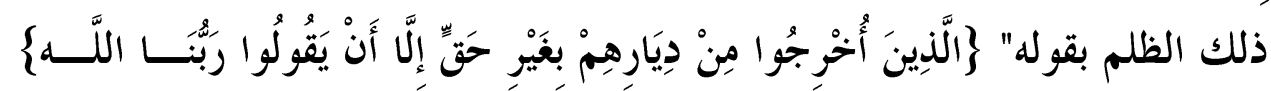
[الحج: · ع] فبين تعالى ظلمهم هذذين الوجهين:

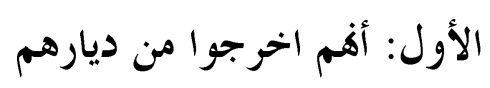

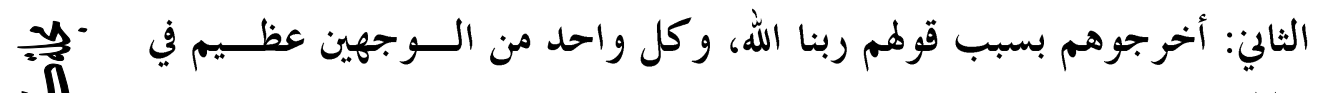

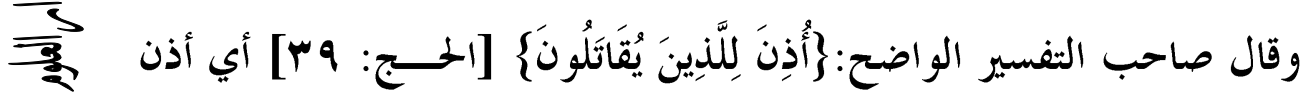

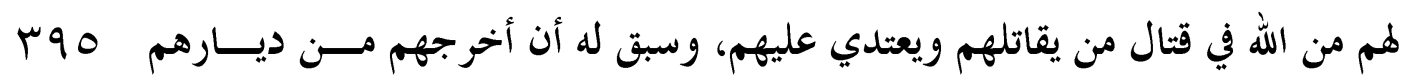

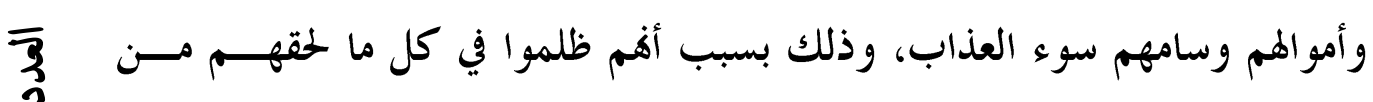

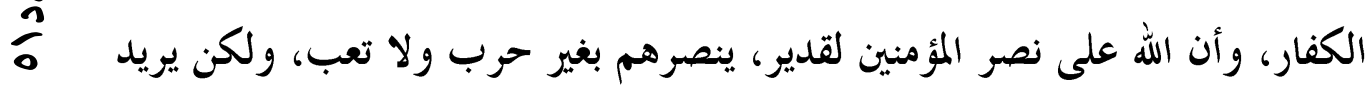

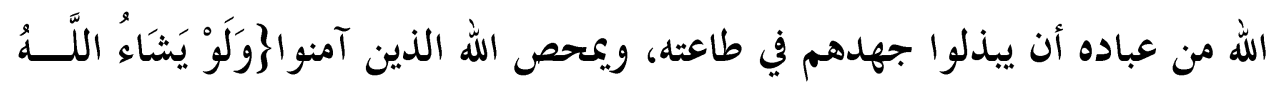

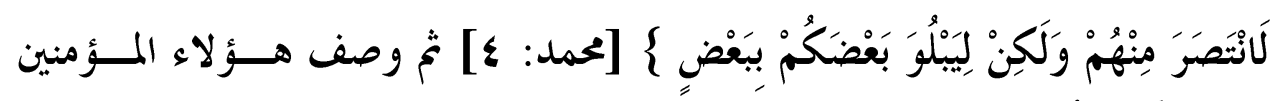

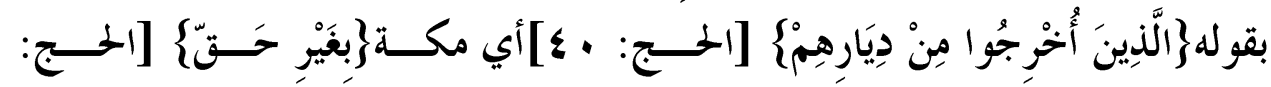

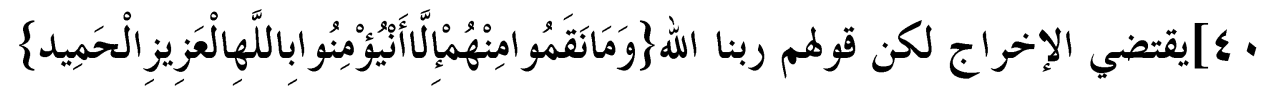

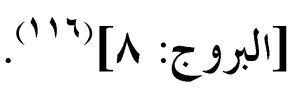

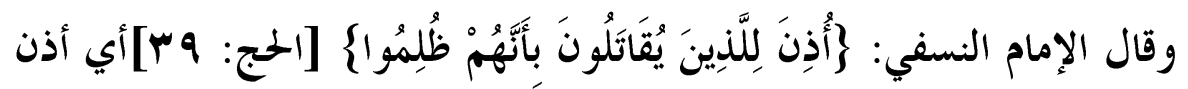

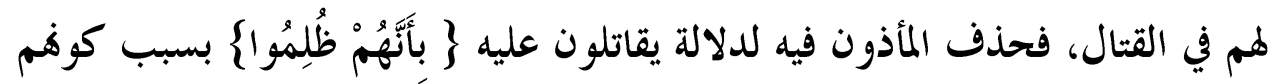

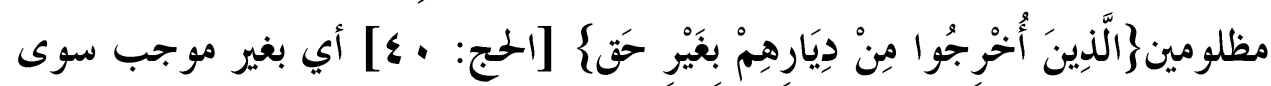

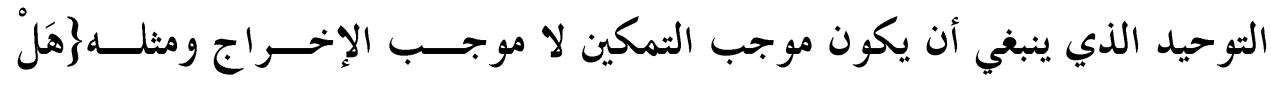

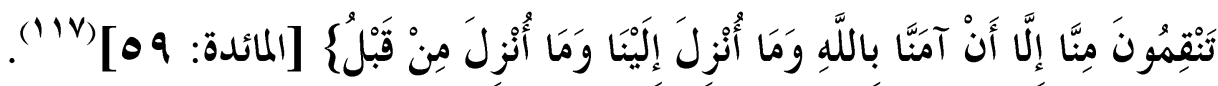


قلت: ففي هذه الآية تشريع للجهاد للأمة الإسلامية الذي مآله إما نصر، وإما شهادة وتضحية بالنفس والنفيس في سبيل الله تعالم، وفي هذا التشريع بيان لقيمــة الوطن الذي شرع الجهاد لأجله. المبحث التاسع: موقف الأنبياء من الوطن المستعرض لكتاب الله تعالم بغرض الكثف عن حال الأنبياء عليهم السلام مع الهع الوطن، يجد أن أنبياء الله تعالى أكبروا الوطن، وعرفوا له حقه دون تزيد أو نقصان، فهم العين السوية التي خلقها الله تعالى، وهم حجة الله على خلقه، أرسلهم الله تعالى الى الى

ينشرون العدل قولا وفعلا.

فنجد أن الأنبياء مثلا في موقف من مواقفهم ارتأوا أن الوطن شيء جليل لكن

وتجدهم في موقف آخر من نبي كريم يكبر الوطن ويدعو له، ويتمنى لو كـــان

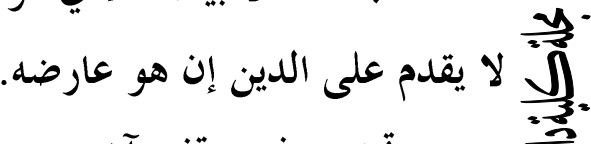

$$
\begin{aligned}
& \text { مالكا عليه كل كيانه. }
\end{aligned}
$$

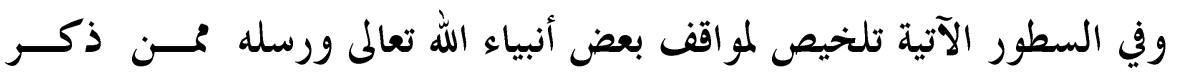

$$
\text { مَّمَ }
$$

سبق أن ذكرنا أنه لا تعارض بين حب الوطن وحب الدين، أو بـــين الانتمـــاء

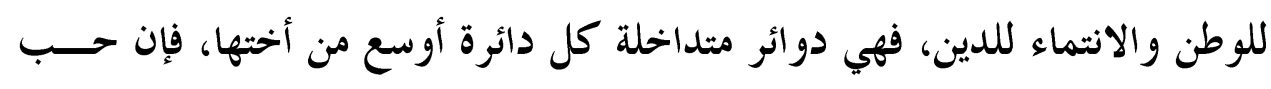
الوطن إنما هو بدافع من الدين وبرعاية منه ومن نصوصه الثريفة. لكن ربما في حال أو بعض أحوال يطلب الدين الخروج من الوطن للدفاع عنده لهنه

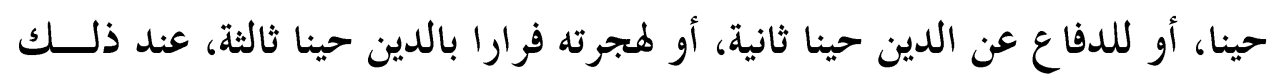
تجد أنه لا يقوم أمام الدين شيء حتى ولو كان هذا الشيء هو الوطن . ظهر هذا الموقف الجليل في حياة الرسل عامة من طوى الله تعالى ذكـــــهم في القر آن الكريم في سورة إبراهيم عليه السلام، حيث آثروا واجب الدين والانتمــــاء 


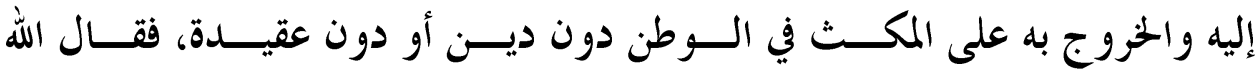

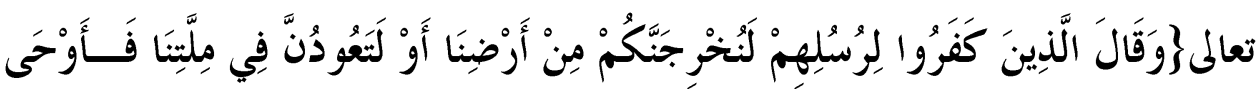

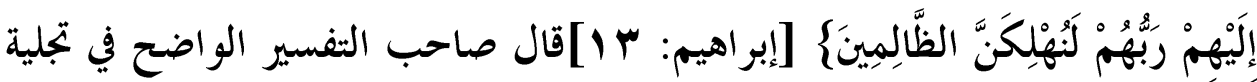

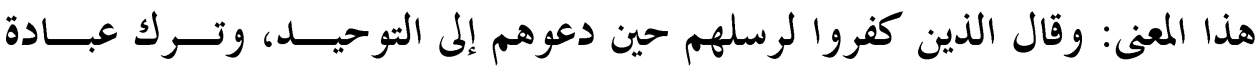

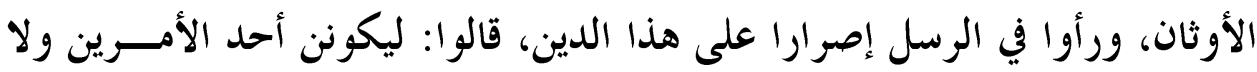

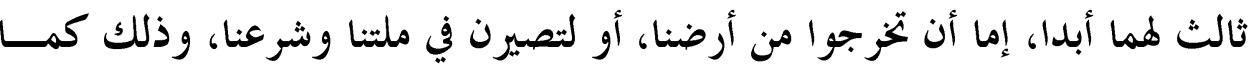

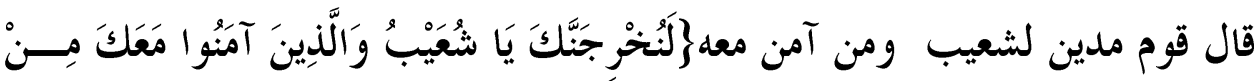

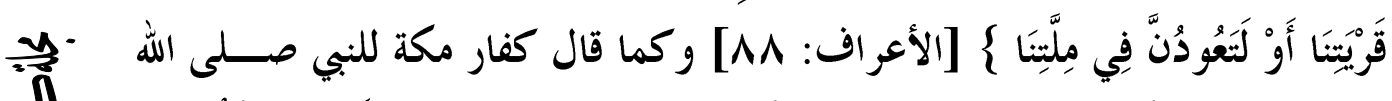
亦

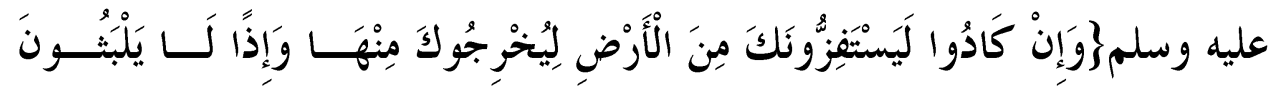

弯

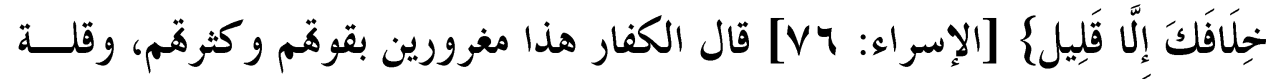

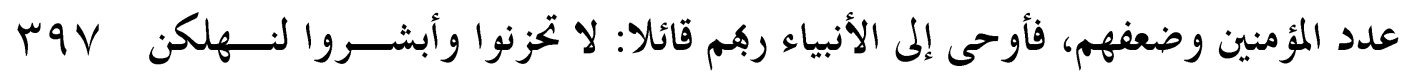

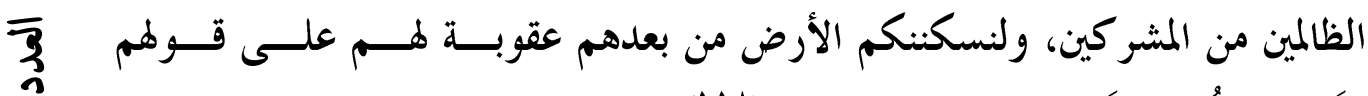
$\frac{2}{6}$

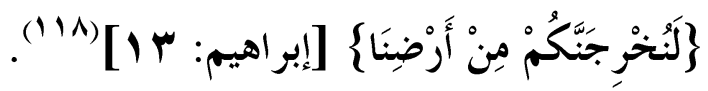

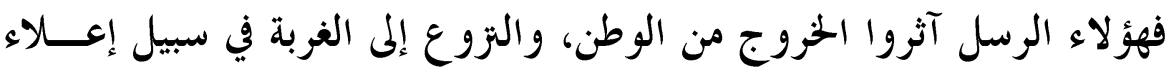

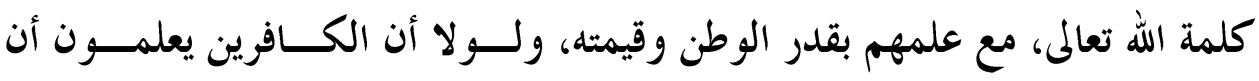

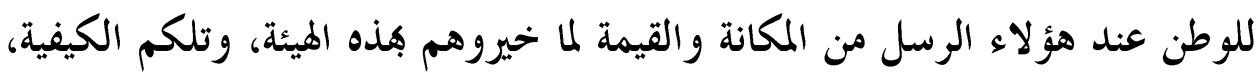

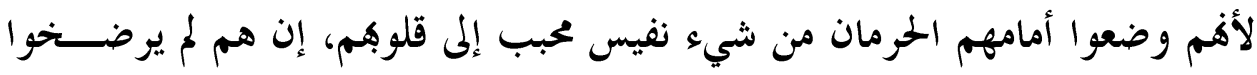

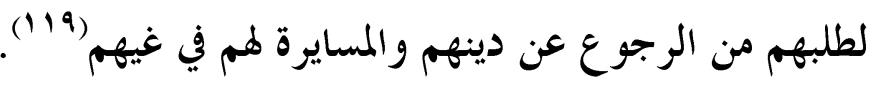

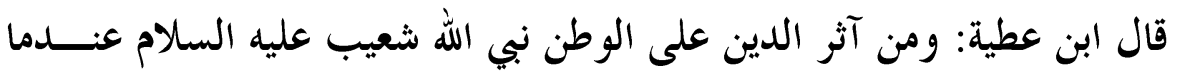

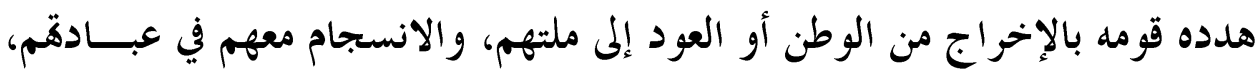

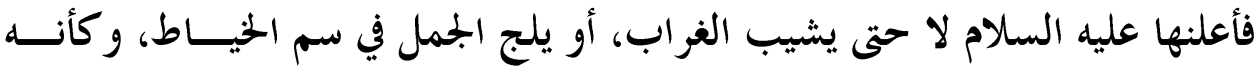

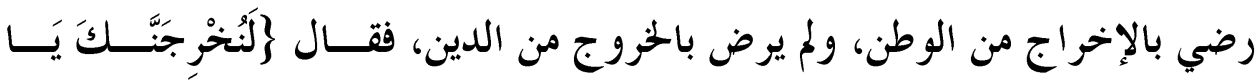

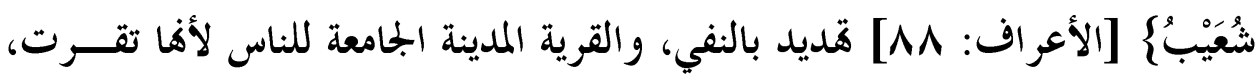




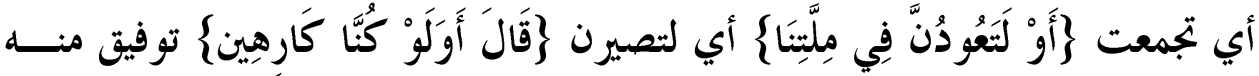

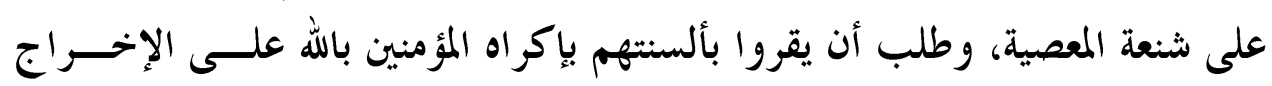

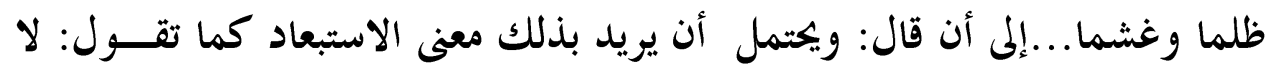

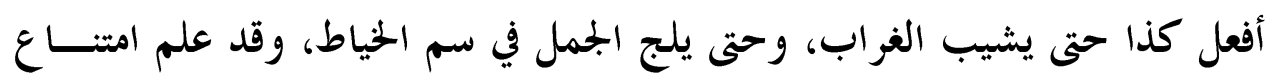
ذلك فهو إحالة على مستحيل (1r.). وقد سبق تفصيل في تفسير هاتين الآيتين بما يغني عن إعادته هنا ضمن مبحسـث

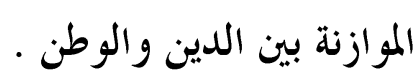

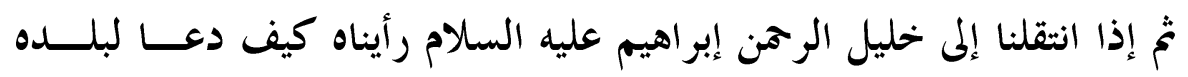

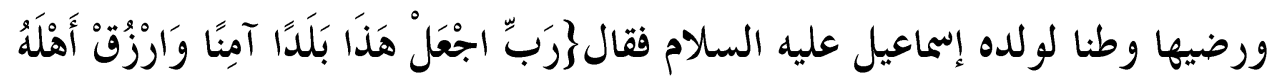

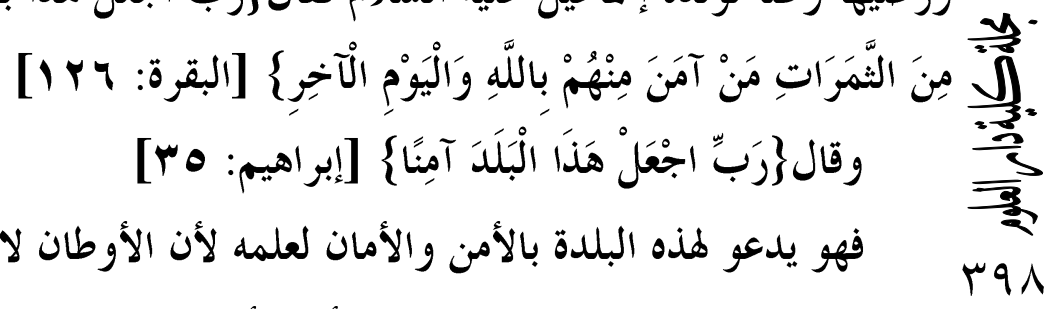

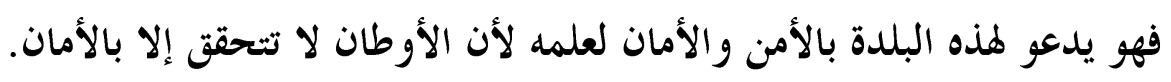

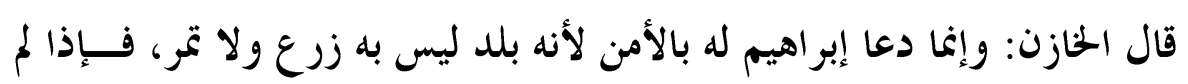
يكن آمنا لم يجلب إليه شيء من النواحي، فيتعذر المقام به، فأجاب الله تعالى إبــــاهيم لهاهيم

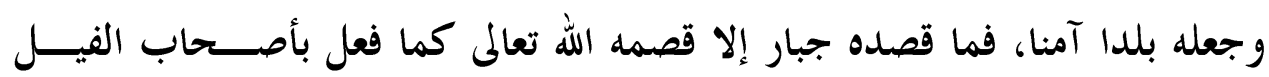

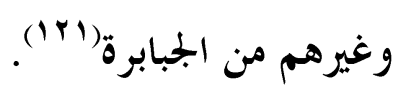

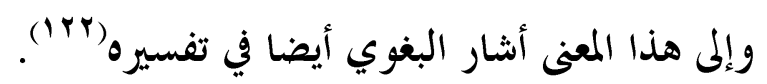

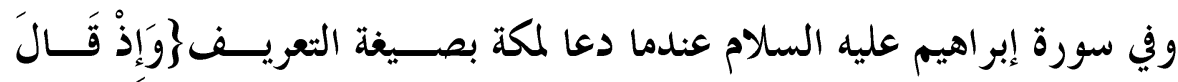

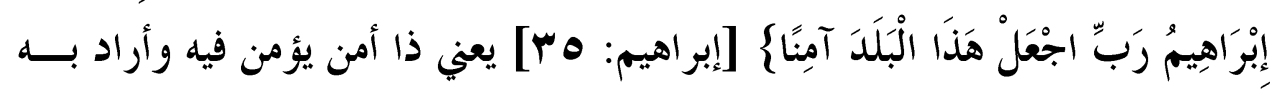

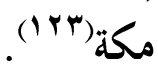

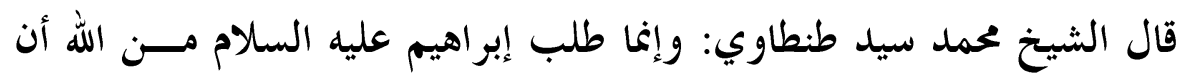
يجعل مكة بلدا آمنا وأن يرزق أهله من الثمرات بما يغنيهم، لأن البلد إذا امتلدت إليه إليه 
ظلال الأمن و كانت مطالب الحياة فيها ميسرة أقبل أهله على طاعة الله تعالى بقلوب مطمئنة، وتفرغوا لذلك بنفوس مستقرة.

قال بعض العلماء: إن الدنيا إذا طلبت ليتقوى بها الناس على إعــلاء كلمـــة

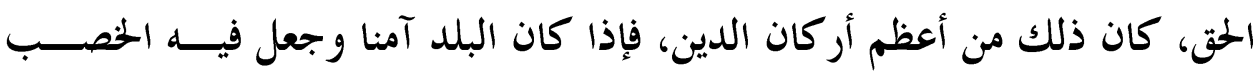

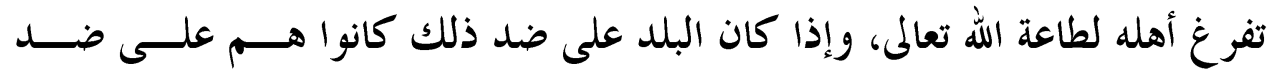
ذلك(

لكن لنظظر حاله عليه الصهلاة والسلام حين تعارض عنده الدين مــع الـــوطن

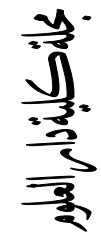

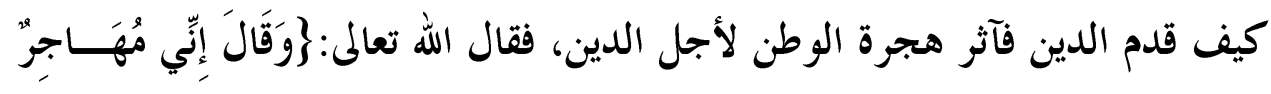

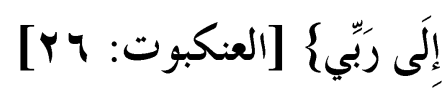

قال ابن الجوزي: فيه قولان : أحدهما: إلى رضا ربي، والثاين: إلى حيث أمسـرين وهب

亨 ربي فهاجر من سواد العراق إلى الشام وهجر قومه المشر كين(ror ). قال الخازن: وهو أول من هاجر إلى الله تعالى وترك بلده وسار إلى حيث أمره الله بالمهاجرة إليه، قيل: هاجر وهو ابن خمس وسبعين سنة(بrا').

وقد سبق الحديث عن توجيه الله تعالم لموسى وأخيه هارون عليهمــــــــالمام باتخاذ الوطن، وبيان أنه حق للإنسان لا يجيا بدونه، يعز بعزه، ويذل بذله.

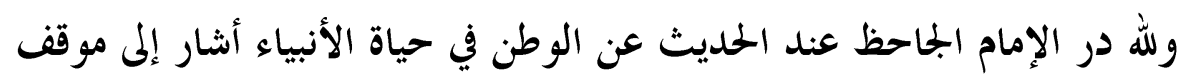

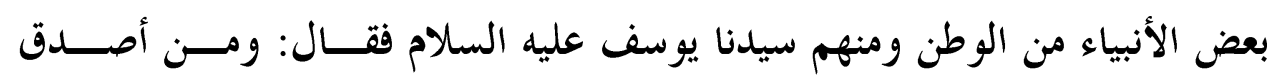
الثو اهد

في حب الوطن أن يوسف عليه السلام لما أدركته الوفاة، أوصى أن تحمل رمته إلى موضع مقابر أبيه وجده يعقوب وإسحاق وإبراهيم عليهم السلام. 
وروى أن أهل مصر منعوا أولياء يوسف عليه السلام من حمله فلما بعــث الله موسى عليه السلام، وأهلك على يديه فرعون وغيره من الأمم، أمره أن يحمل رمتــهـ إلى تربة يعقوب بالثام وقبره علم بأرض بيت المقدس بقرية حسامى.

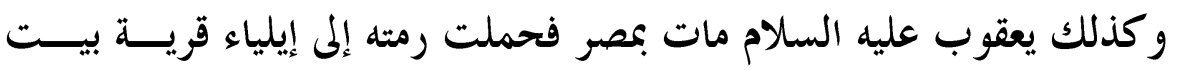
المقدس، وهناك قبر إسحاق بن إبراهيم عليهما السلام (rV (IV). قال الجحاحظ: ومن حب الناس للوطن وقناعتهم بـــالعطن أن إبـــــاهيم عليـــه

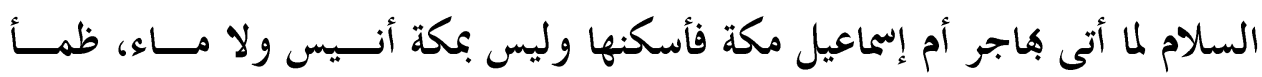

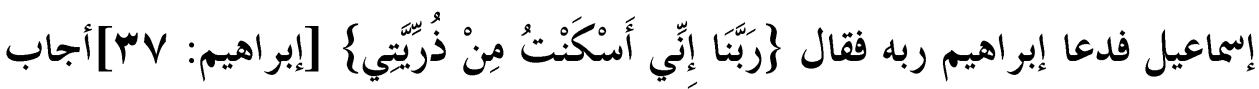

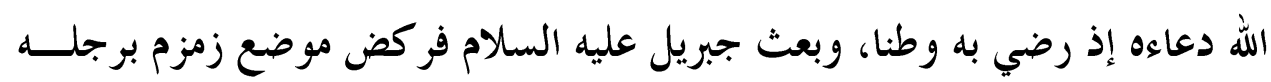

ومر بإسماعيل وأمه فرقة من جرهم فقالو ا: أتأذنون لنا أن نتزل معكم؟ فقالـــت

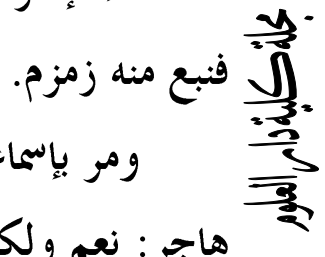

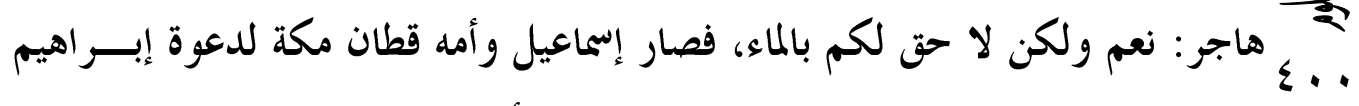
عليه السلام، نعم وهي مع جدوبيتها خير بقاع الأرض إذ صارت حرما، ولإسماعيل

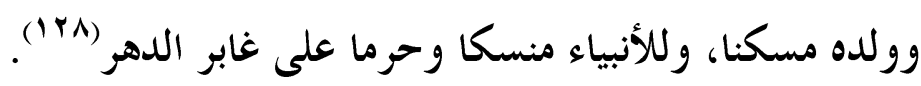
وممن تمسك من بني إسرائيل بحب الأوطان خاصة ولد هـــارون وآل داوود، لم

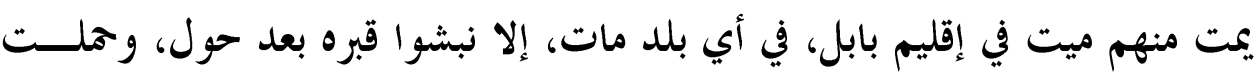
رمته إلى موضع يدعى الحصاصة بالثام فيودع هناك حولا، فإذا حال عليه الحـــول

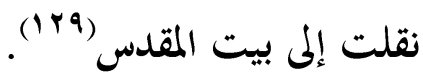
ولعله إذا لم يكن فيما سبق من إيراد لحال بعض الأنبياء كيوسف عليه السلام ويعقوب عليه السلام ما يصح الاستناد إليه، فيمكن أن يكون من قبيل الاستئناس في ضمن ما مضى من الآيات، التي تحدثت عن حال الأنبياء والرسل مع الـــوطن، والله تعالى أعلم. 


\section{الحاتمة نسأل الله تعالى حسنها}

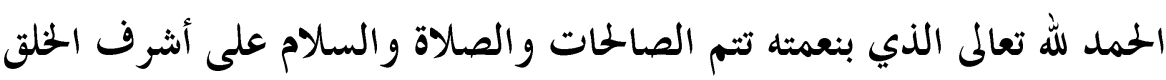
وحبيب الحق سيدنا محمد صلى الله عليه وعلى آله وأصحابه أبمعين وسلم تســليما كثيرا،6،، وبعد

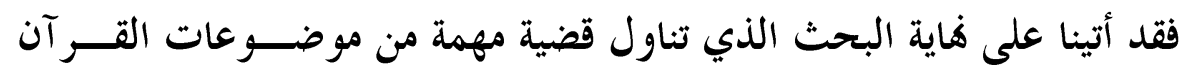

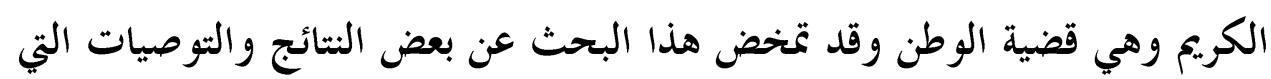
بانت من خلال معايشتي له هذه أهمها

瓷 أولا: أهم النتائج

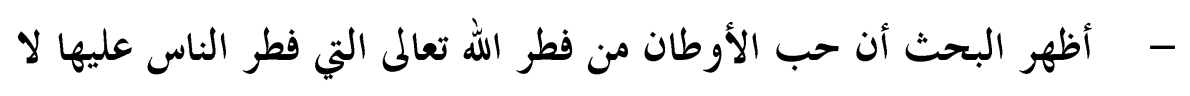
يشذ عن ذلك إلا ذوو الفطر المعوجة.

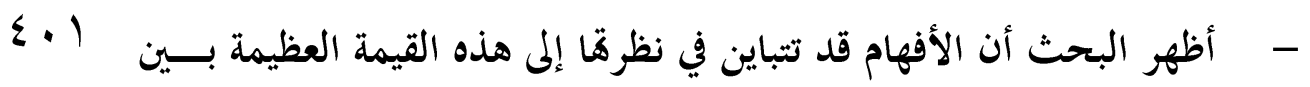

$\frac{\overline{3}}{3}$ الإفراط والتفريط والحقى وسط بين رذيلتين.

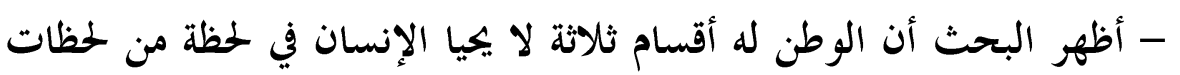

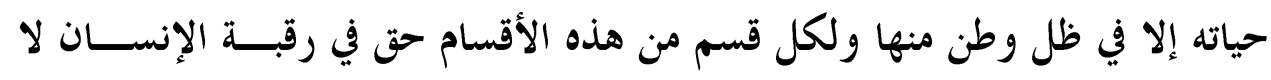

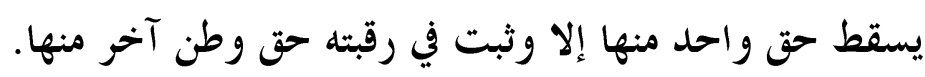

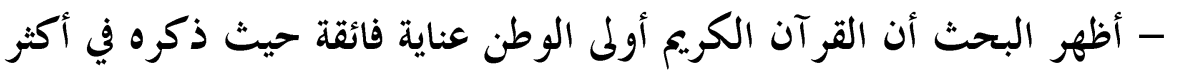
من خمسين آية. - أظهر البحث أن القر آن الكريم ينظر إلى موضوع الوطن علــى أنسه حســـ ل لإلنسان.

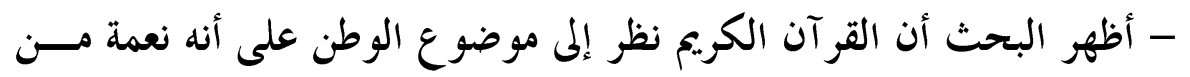
نعم الله تعلى على الإنسان تستحق الشكر كسائر نعم الله تعالى. 
- أظهر البحث أن لا تعارض بين الدين والوطن فإن الانتماء للوطن لا ينــافي بحال الانتماء للدين بل من متممات الانتماء للدين الانتماء للوطن.

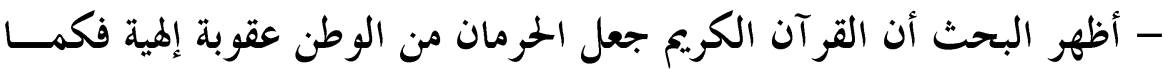
امتن سبحانه على أناس بنعمة الوطن فقد عاقب أناسا آخرين بالإخراج من أوطافم.

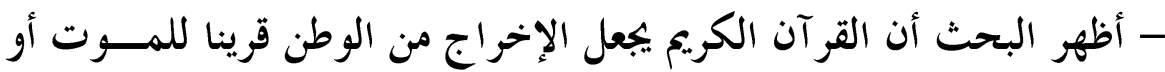

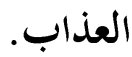
- أظهر البحث أن القر آن الكريم يجعل هجرة الوطن تارة محمودة وتارة أخرى مذمومة تأسيسا على الموازنة بين الوطن والدين. - أظهر البحث أن القرآن الكريم شرع الدفاع عن الوطن وجعل بذل الغالي والنفيس في سبيله من القربات إلى الله تعالى.

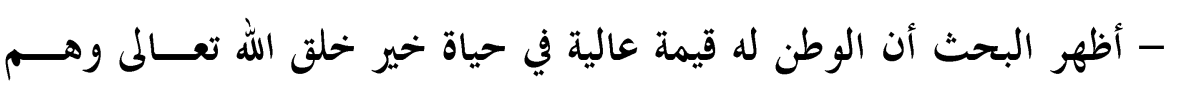
الأنبياء كما حكى القر آن الكريم. ثانيا: أهم التوصيات

- - ميكن أن تعقد سلسلة من الندوات للتعريف بقيمة الوطن من خلال نظرة 预. القر آن الكريم نظرا لما للوطن من أهمية قصوى في حياة البشر.

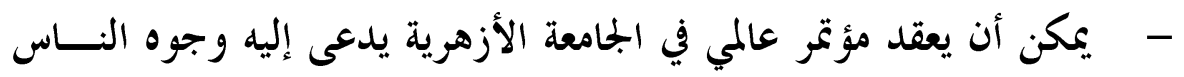

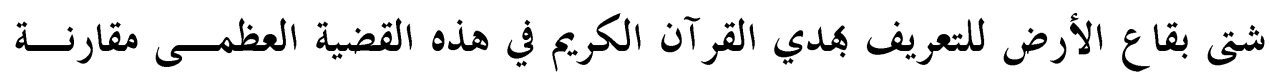
بضلالات البعض المنتشرة هنا وهناك تجاه هذه القضية. - يمكن أن يستحدث الأزهر الشريف في مراحله الدراسية المختلفـــة مقـــررا دراسيا حول موضوع الوطن بل ويدعو الجحامعات والمدارس الأخـــــي في مصــــا الحبيبة ووطننا العربي أن يعمموا هذا المقرر الدراسي في مدارسهم وجامعاقم ودولهم 
حتي يشيع الهدي القر آين العظيم الذي أتى على كل شاردة وواردة في هذه القضــية بالمعالجة و العناية.

وبعد فهذه أهم النتائج والتوصيات التي بانت لي من خــالال معايثــتي لهــــا البحث والله تعالم من وراء قصدي وهو حسبي ونعم الو كيل. ثبت المراجع والمصادر التي استقى البحث منها مادته العلمية

ا- - أنوار التزيل وأسرار التأويل للعلامة ناصر الدين أبي سعيد عبدالله بن عمر بن محمد

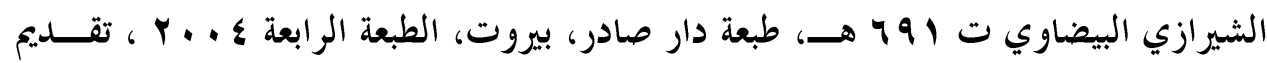

矞 E. Y

$\overline{3}$ محمود عبدالقادر الأرناؤوط. r- أحكام القر آن لأبي بكر محمد بن عبدالله بن محمد بن عبدالله المعروف بابن العــربي

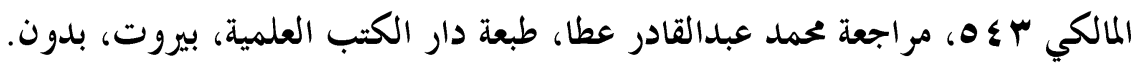

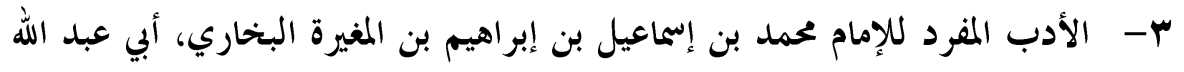

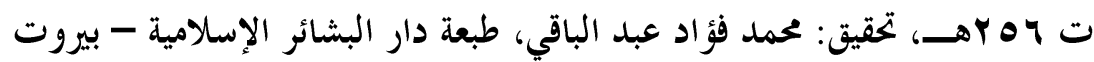

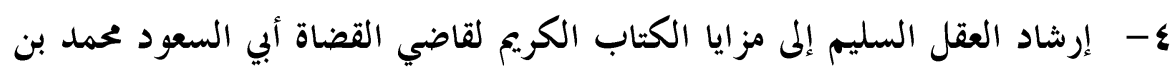

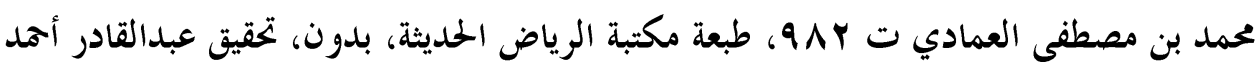
عطا.

ه- - الأعمال الكاملة للإمام الثيخ محمد عبده، تحقيق وتقديم محمد عمارة، طبعــة دار

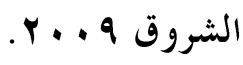

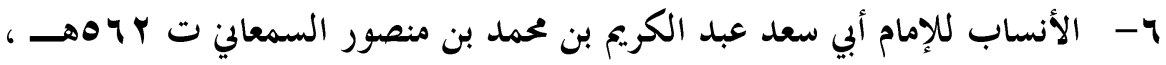

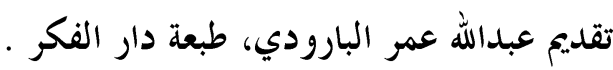

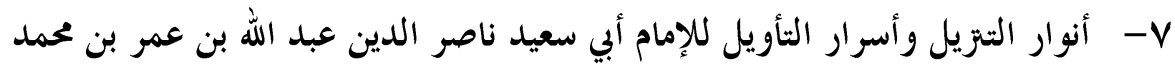

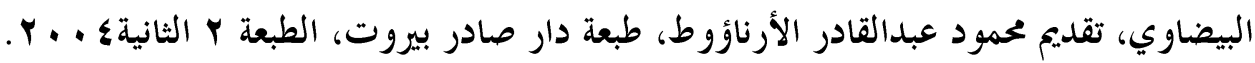

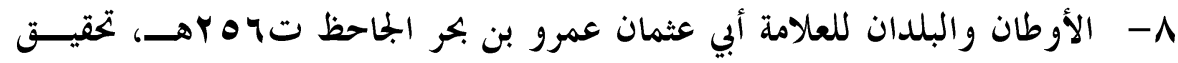

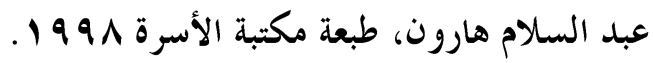

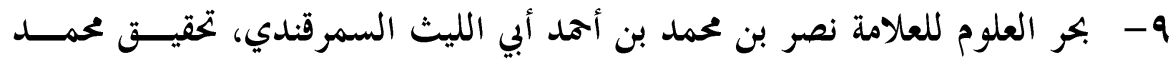

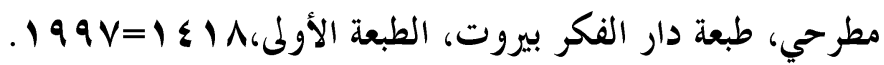


• 1- البحر المديد في تفسير القر آن الججيد لأبي العباس أحمد بن محمد بن المهدي بن عجيبة

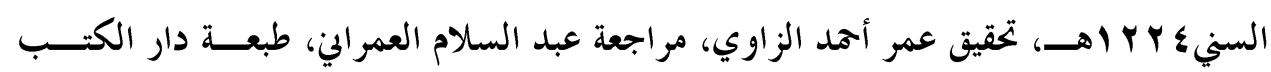
العلمية، الطبعة الثالثة • 1 . . . 1 ا-تاج العروس من جواهر القاموس، للإمام محمد مرتضى الزبيدي، تحقيق عبد الكريم

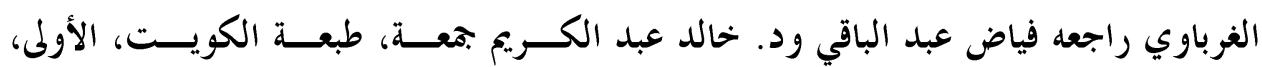

$$
r . .1=1 \leqslant r r
$$

r ا - تاريخ مدينة دمشق لأبي القاسم علي بن محمد بن هبة الله بن عبـــد الله الشـــافعي

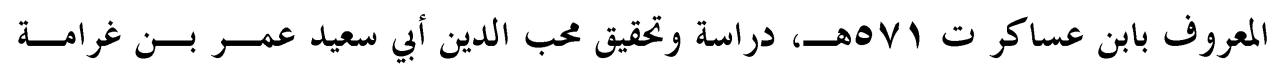

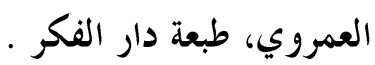

با ا- التحرير والتنوير للأستاذ العلامة محمد الطاهر ن عاشور طبعة الــدار التونسـية

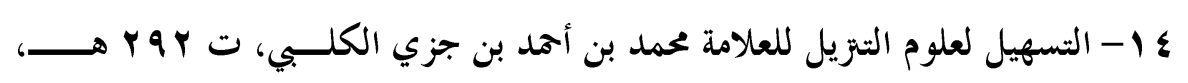
\& $191 \varepsilon$ ع

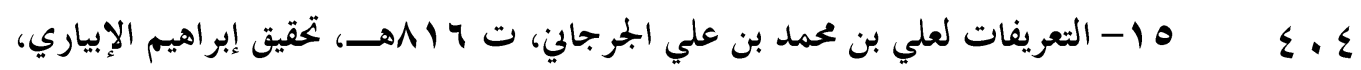

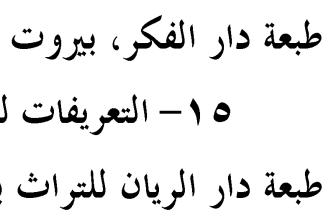

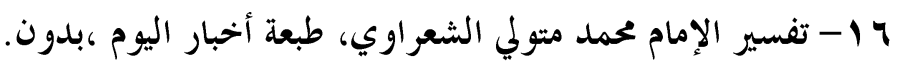
IV

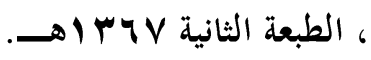

1 ا- تفسير القر آن العظيم لأبي الحسن علم الدين علي بن محمد بــن عبـــد الصــمـد

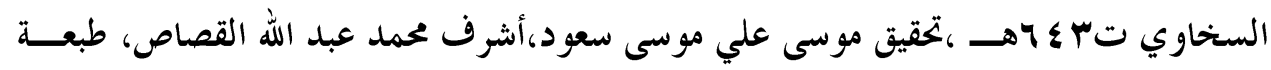

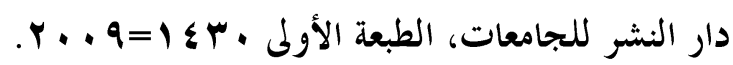

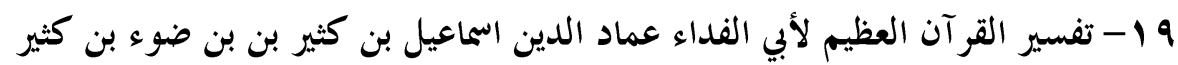

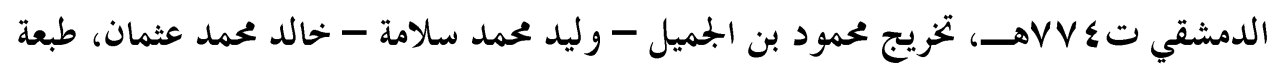

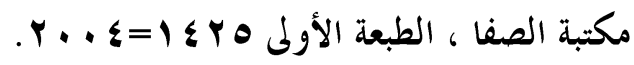




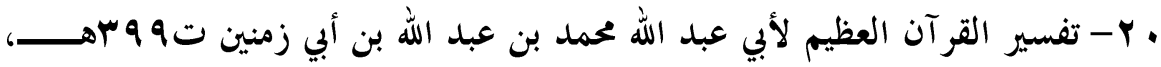

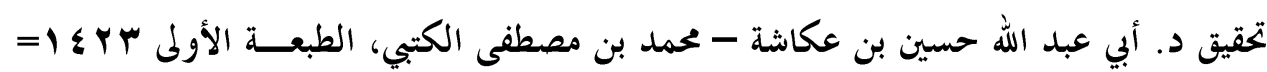
$r . . r$

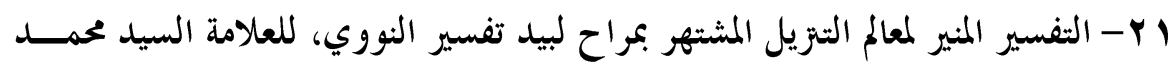

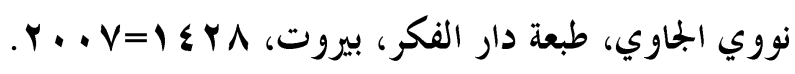

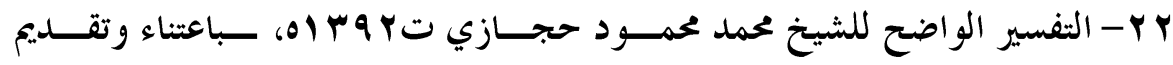

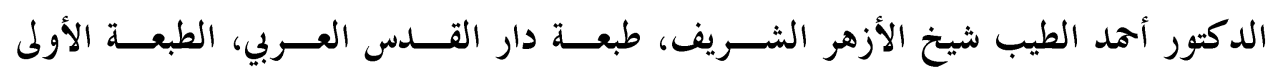
$r+\mid V=1 \leqslant r \Lambda$

哥. $\varepsilon .0$

$\frac{\overline{3}}{3}$

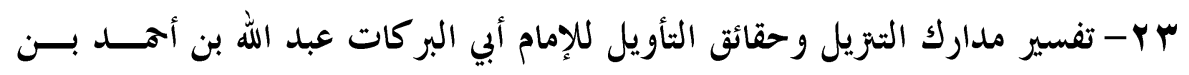

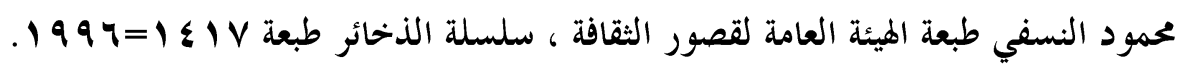

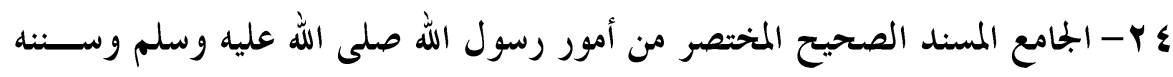

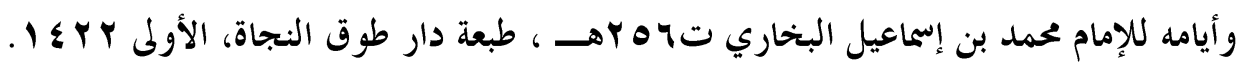

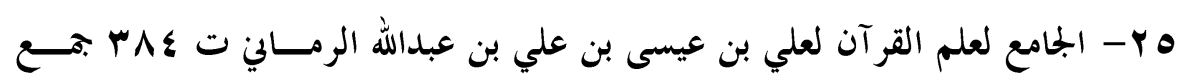

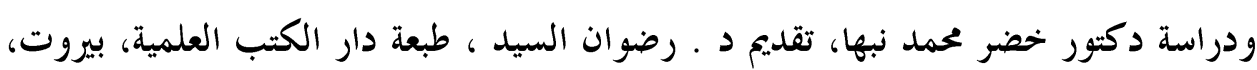

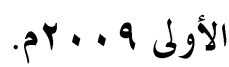
צ Y - الجواهر الحسان في تفسير القرآن لأبي زيد عبد الرحمن بن محمد بن مخلوف الثعالبي

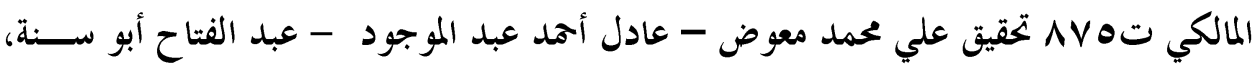

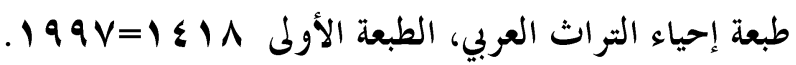

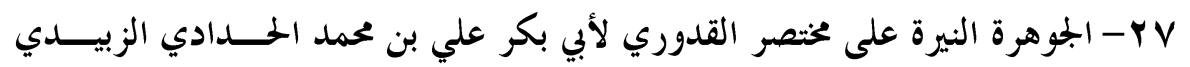

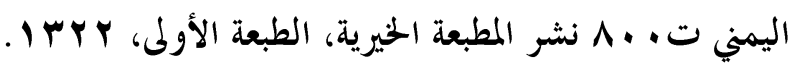

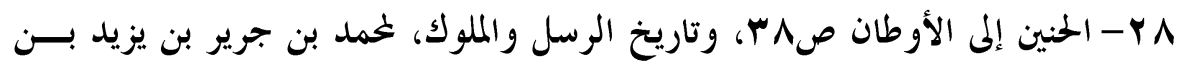

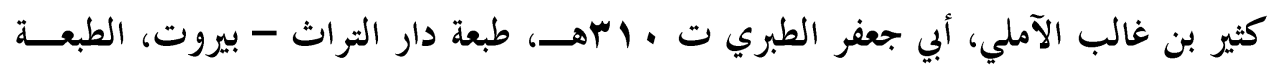

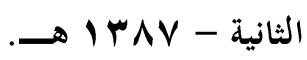

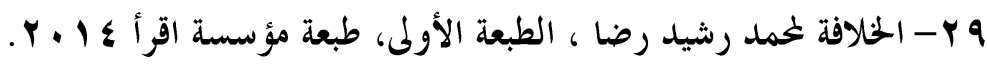

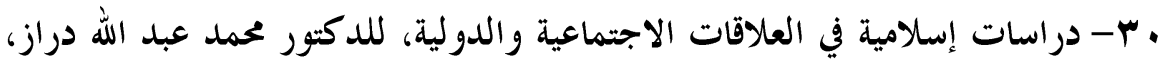


اس إ- دوائر الانتماء وتأصيل الهوية تحرير أ.د. نادية مصطفى - أسامة مجاهد -ماجسـدة

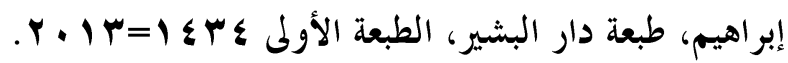

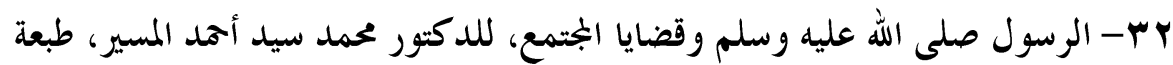

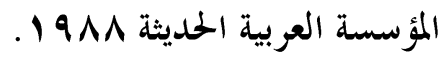
بr- الروضة الندية شرح الدرر البهية لصديق بن حسن بن علي الحســني القنسوجي البخاري، طبعة دار الجيل، بيروت، بدون.

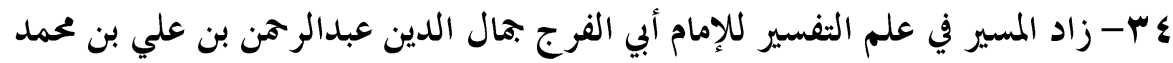

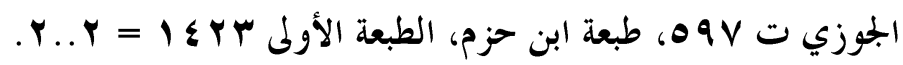

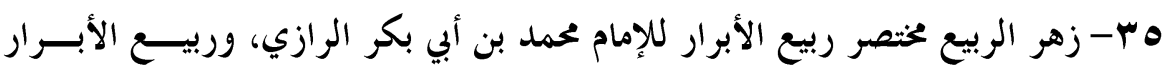

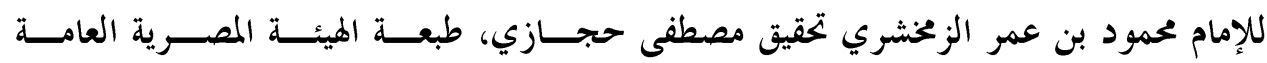

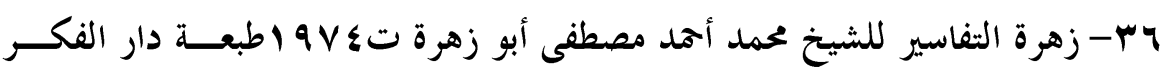
ب. 19 A V

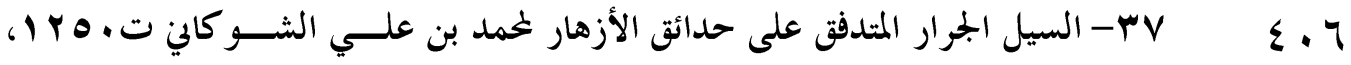

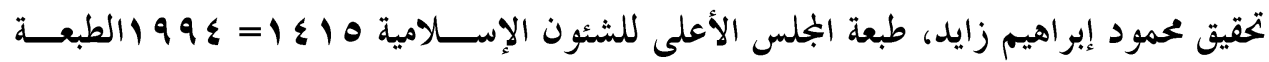

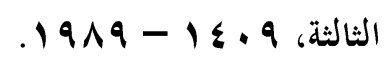
^ץ- الفقه على المذاهب الأربعة لعبد الرحمن الجزيري، طبعة دار الريان للتراث، بدون. $\overline{3}$
$\frac{1}{0}$

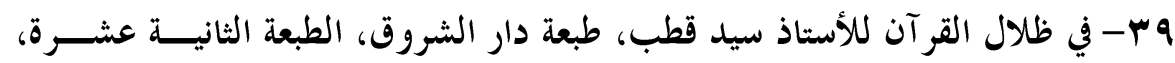

$$
.19 \wedge 7=1 \varepsilon \cdot 7
$$

• ع - الكشاف عن حقائق غو امض التزيل وعيون الأقاويل في وجوه التأويل للعلامة جار

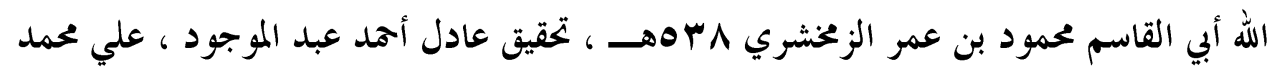

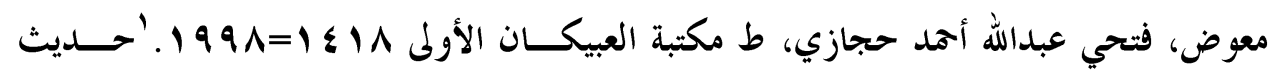
القر آن عن نعمة الأمان للشيخ محمد سيد طنطاوي شيخ الأزهر الأسبق طبعة مجمع مطابع الأزهر

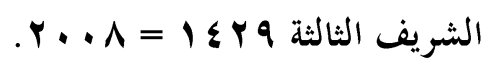


1 إ- لباب التأويل في معابي التزيل للإمام علاء الدين علي بن محمد بن إبراهيم الحخازن

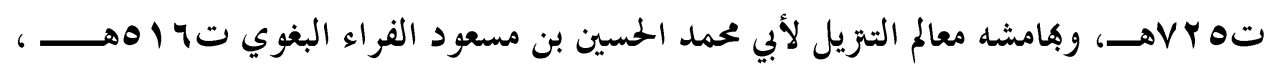

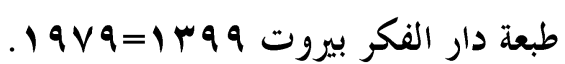

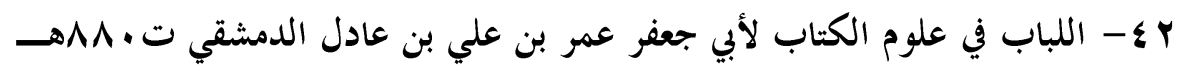

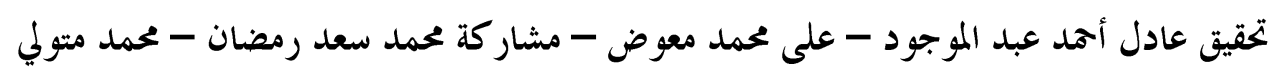

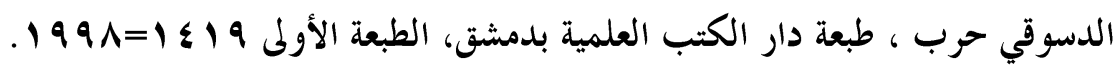

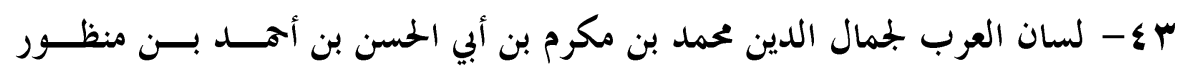

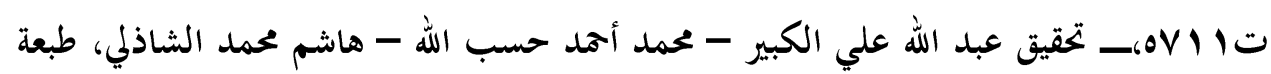
دار المعارف .

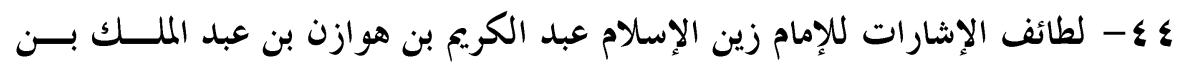

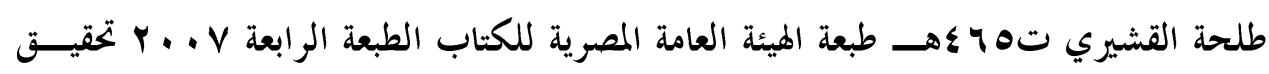
$\varepsilon \cdot V$

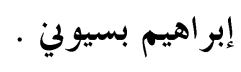

$\frac{\overline{3}}{3}$

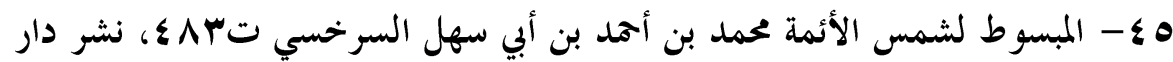

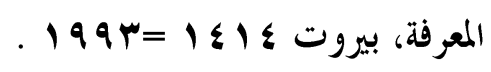

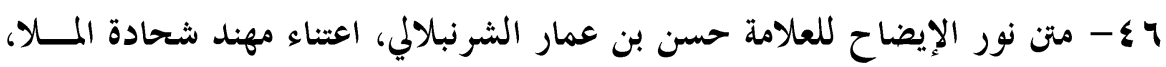

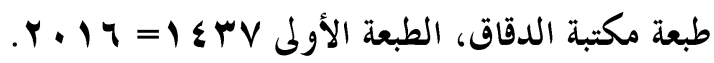
\&V

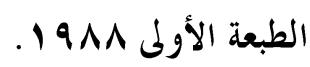

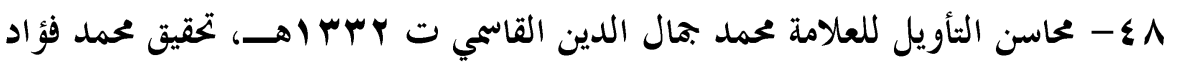

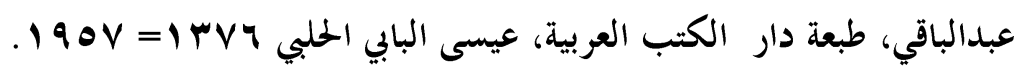

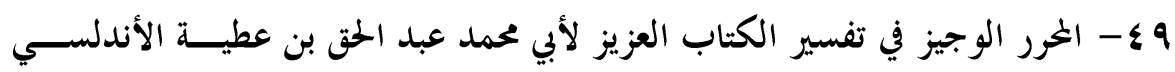

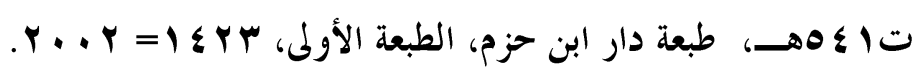

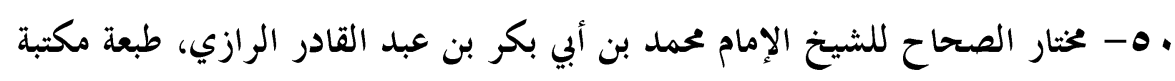

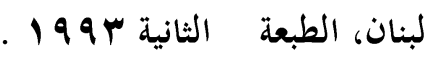
اهـ- المسند المختصر بنقل العدل عن العدل إلى رسول الله صلى الله عليه وسلم للإمام

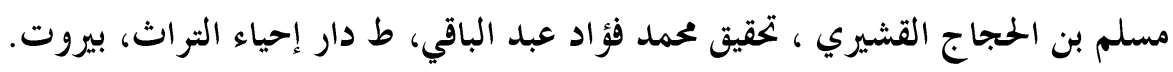


r - المسند للإمام أحمد بن حنبل الشيبالي، تحقيق شعيب الأرنـــؤوط - ط مؤسســة

$$
\text { الرسالة - الأولى ابr| }
$$

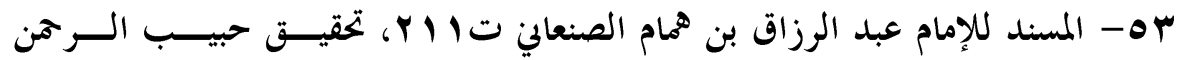
الأعظمي

$$
\text { ط المكتب الإسلامي - بيروت، ط ب، ب مـ 1. }
$$

ـ هـ المسند للإمام أبي يعلى أحمد بن علي بن المثنى الموصلي، ط دار المأمون ، الطبعـة

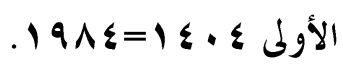

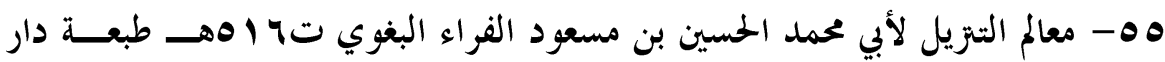

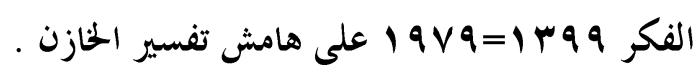

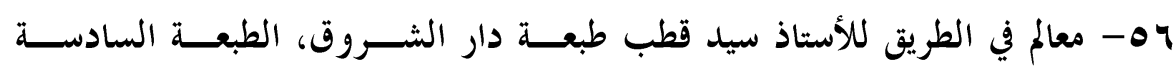

$$
.19 \vee 9=1 \text { \% } 9
$$

V - المعجم المفهرس لألفاظ القر آن الكريم يخمد فؤاد عبد الباقي طبعة دار الحسـديث

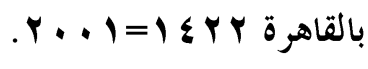

$$
\varepsilon \cdot \Lambda
$$

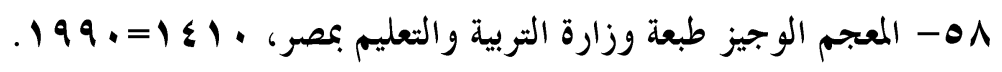

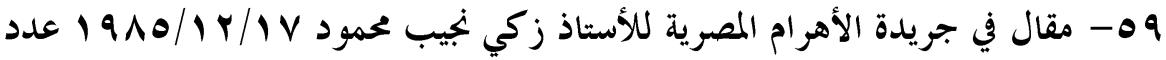

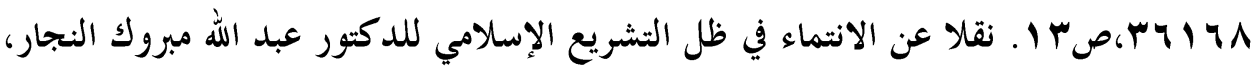

• $4-$

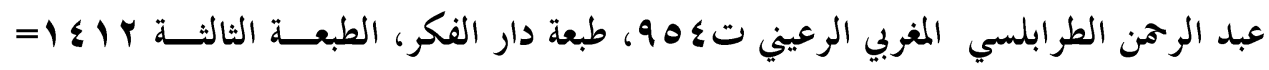

ا ا- الموسوعة الفقهية الكويتية ، أصدرةما وزارة الأوقاف والثئون الإسلامية بالكويت،

$$
\text { الطبعة الأولى، YY }
$$

r ب- النهاية في غريب الحديث والأثر لبجد الدين أبي السعادات المبارك بن محمد بن محمد

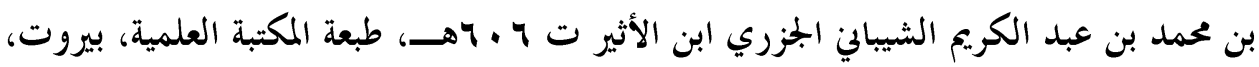

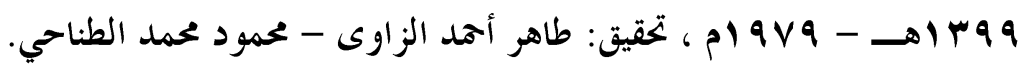


بـ- الوجيز في تفسير القر آن العزيز للإمام أبي الحسن علــى بــن أحــــد الواحسـدي

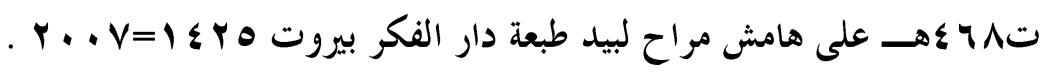

\section{الهموامش والإمالات}

' - تاريخ مدينة دمشق لأبي القاسم علي بن محمد بن هبة الله بن عبد الله الشافعي المعروف بابن

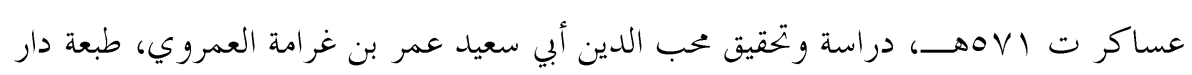

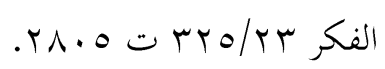

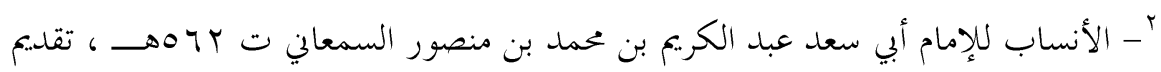

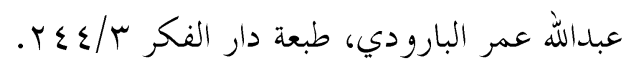

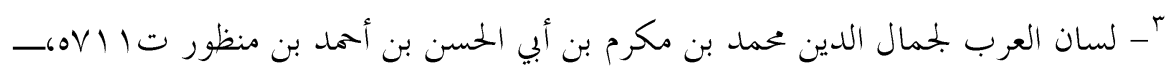

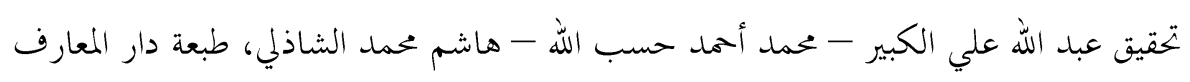

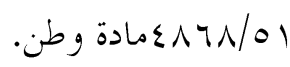

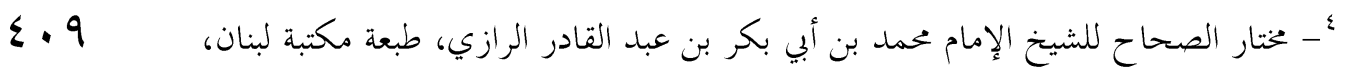
$\frac{\overline{3}}{3}$

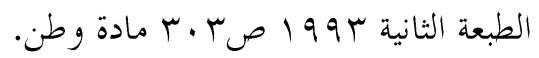

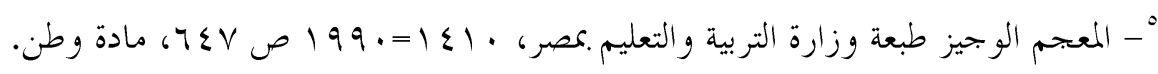

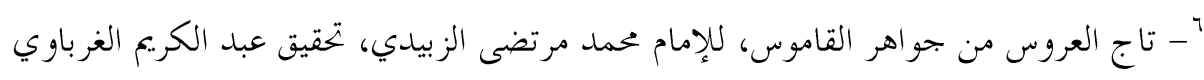

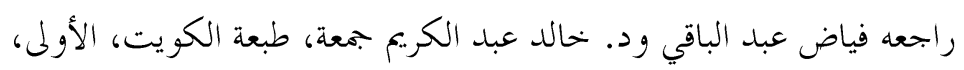
r

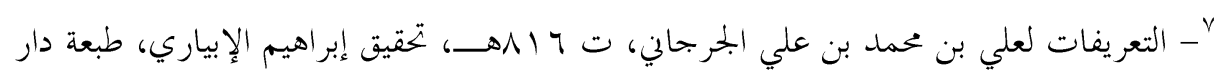

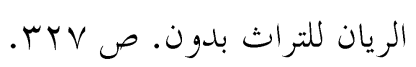
^- الموسوعة الفقهية الكويتية ، أصدرها وزارة الأوقاف والشئون الإسلامية بالكويت، الطبعة

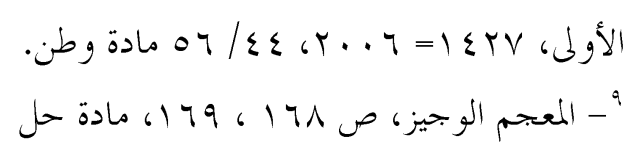

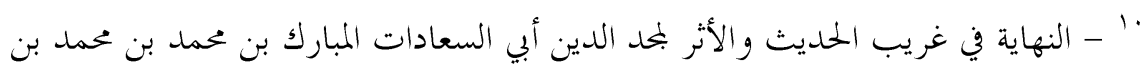

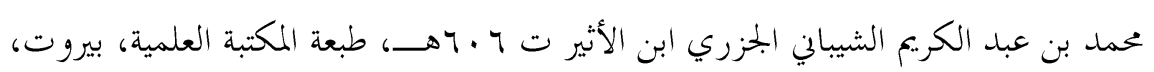

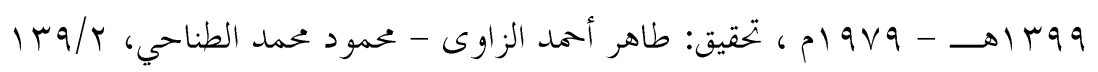

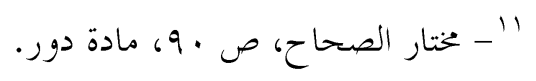


'ب'- الروضة الندية شرح الدرر البهية لصديق بن حسن بن علي الحسني القنوجي البخاري، طبعة

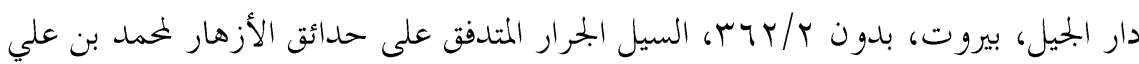
الشو كاين ت .0 ب ال، تحقيق محمود إبراهيم زايد، طبعة المحلس الأعلى للشئون الإسلامية . $\{\wedge 1 / 199 \leqslant 6 \leqslant=1 \leqslant 10$

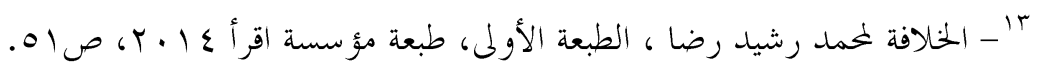

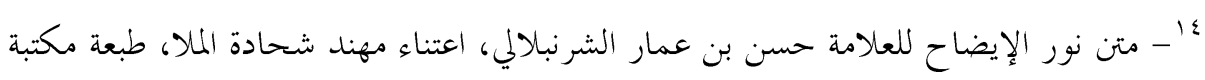

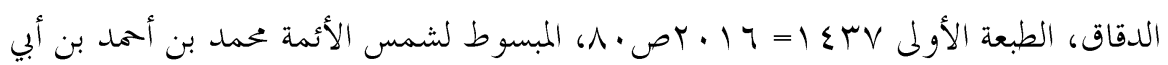

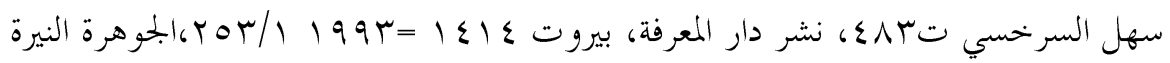
على مختصر القدوري لأبي بكر علي بن محمد الحدادي الزبيدي اليمني ت . . م نشر المطبعة

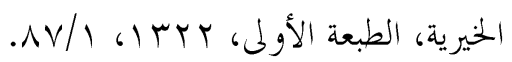
ه' - مواهب الجليل شرح حختصر خليل لشمس الدين أبي عبد الله محمد بن محمد بن عبد الرحمن

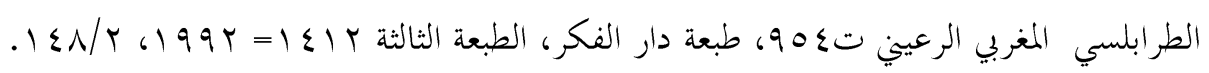
17' - الفقه على المذاهب الأربعة لعبد الرحمن الجزيري، طبعة دار الريان للتراث، بلدون .

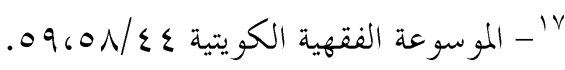

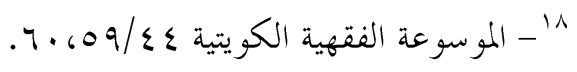

19 - المعجم المفهرس لألفاظ القر آن الكريم عممد فؤاد عبد الباقي طبعة دار الحديث بالقاهرة

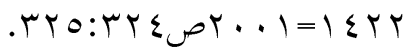

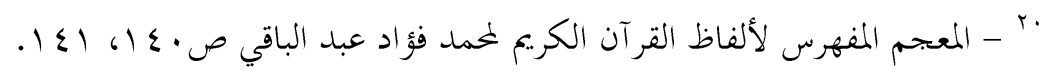

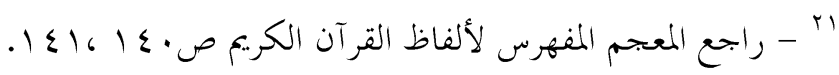

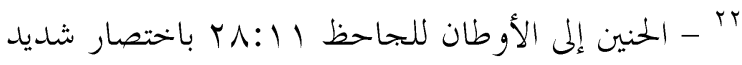
rr - زهر الربيع مختصر ربيع الأبرار للإمام محمد بن أبي بكر الرازي، وربيع الأبرار للإمام محمود

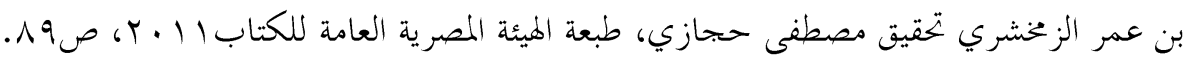

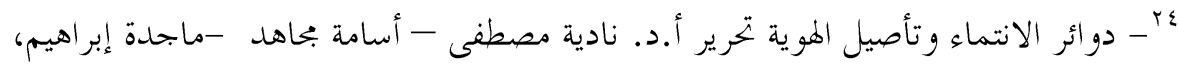

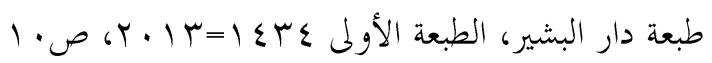


ro - في ظلال القر آن للأستاذ سيد قطب، طبعة دار الشروق، الطبعة الثانية عشرة،

$$
\begin{aligned}
& . V \cdot N / r \text { (19人 } \tau=1 \varepsilon \cdot T \\
& \text { rr } \\
& \text { rr }
\end{aligned}
$$

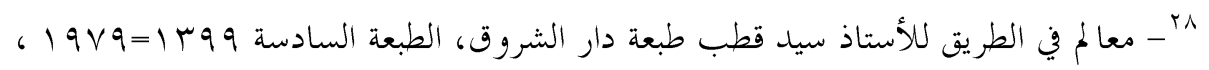

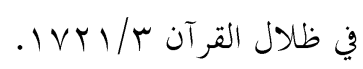

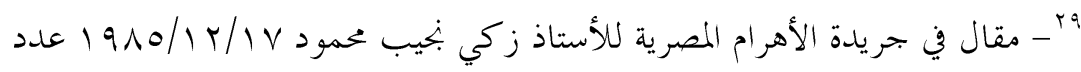

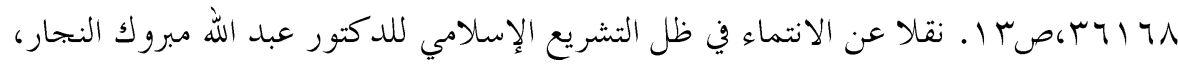

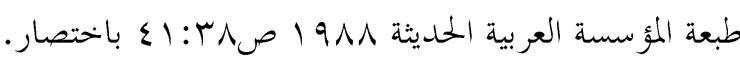

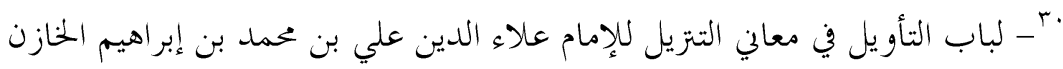

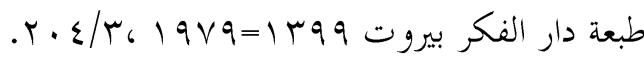

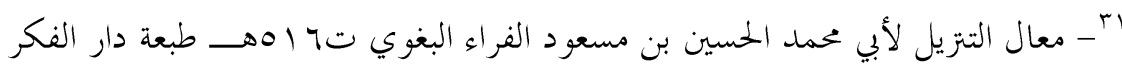

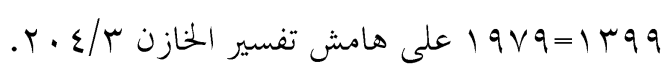
rr

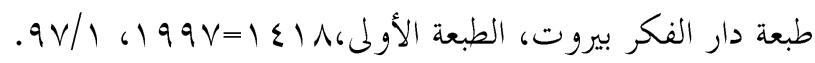
rr

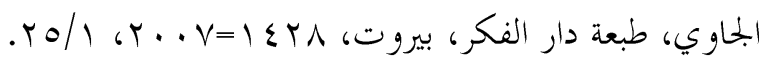

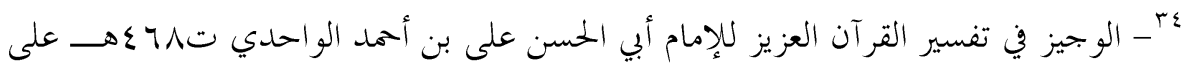

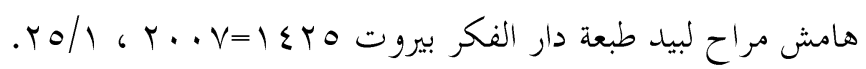

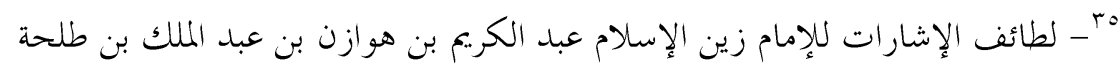

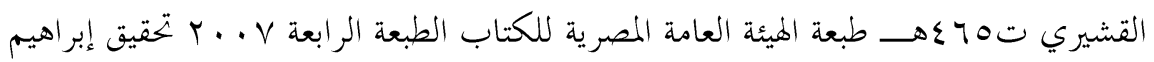

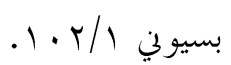
بr - زهرة التفاسير للشيخ محمد أحمد مصطفى أبو زهرة تع 9 الطبعة دار الفكر العربي الطبعة السابعة 


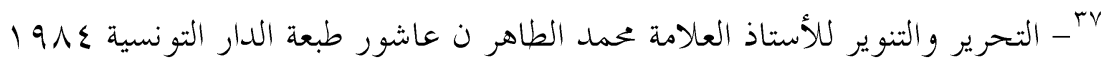
. $r \vee \leqslant / 1 V_{6}$ مَ'الأدب المفرد لإمام محمد بن إسماعيل بن إبراهيم بن المغيرة البخاري، أبي عبد الله ت T ه هــ، تحقيق: محمد فؤاد عبد الباقي، طبعة دار البشائر الإسلامية - بيروت

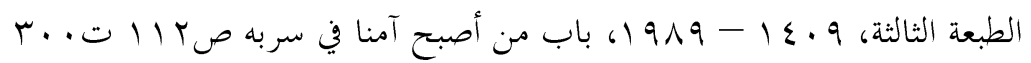

qَrالكشاف عن حقائق غو امض التتزيل وعيون الأقاويل في وجوه التأويل للعلامة جار الله أبي

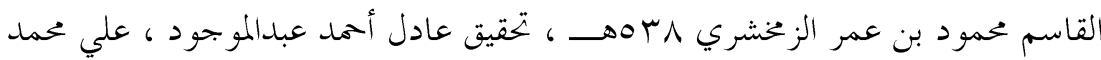

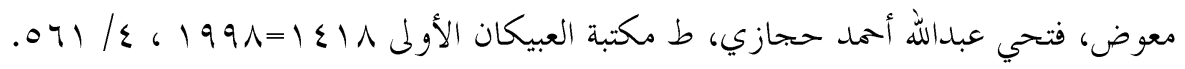
•ح حديث القر آن عن نعمة الأمان للشيخ محمد سيد طنطاوي شيخ الأزهر الأسبق طبعة بحمع

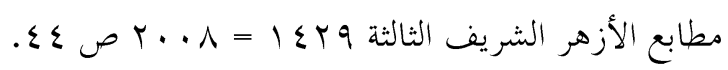

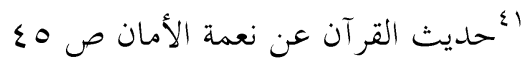

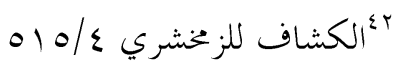

باء- أنوار التزيل وأسرار التأويل للعلامة ناصر الدين أبي سعيد عبدالله بن عمر بن محمد

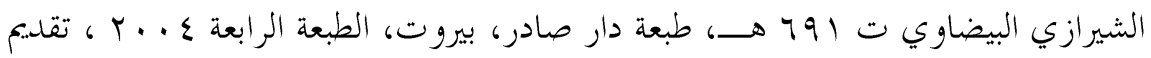

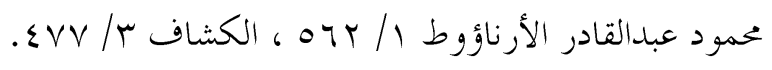
§؛ - الجامع لعلم القرآن لعلي بن عيسى بن علي بن عبدالله الرماتي ت ع مب جمع ودراسة دكتور خضر محمد نبها، تقلديم د ـ رضوان السيد ، طبعة دار الكتب العلمية، بيروت، الأولى 9 . . ب م ص $9 \cdot 9$

" - محاسن التأويل للعلامة محمد جمال الدين القاسمي ت بسم اهــ، تحقيق محمد فؤاد

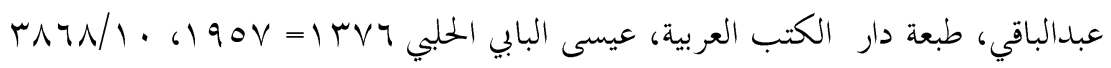

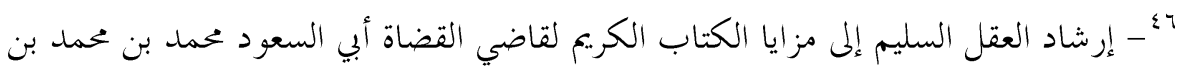
مصطفى العمادي ت r r 9، طبعة مكتبة الرياض الحديثة، بلدون، تحقيق عبدالقادر أحمد عطا، $01 \cdot / r$

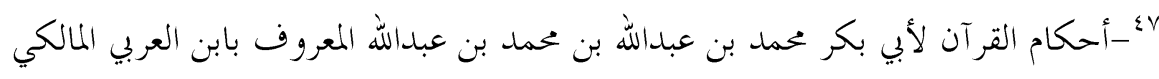

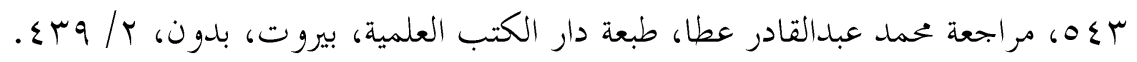




$$
\text { 9 }
$$

•-- أخر جه الإمام أحمد بن حنبل الشيباني في مسنده تحقيق شعيب الأرناؤوط - ط مؤسسة

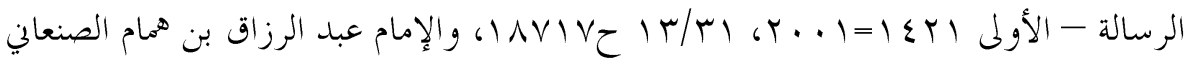
في مسنده ت ال| أح، تحقيق حبيب الرحمن الأعظمي ط المكتب الإسلامي - بيروت، ط ب، م ·ع 1، باب فضل الحرم وأول من نصب أنصاب الحرم

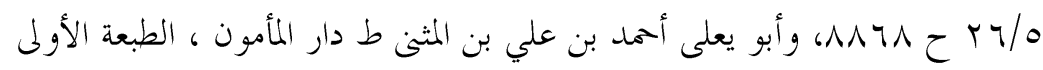
.rTTr乙 $79 / 0$. $19 \wedge \varepsilon=1 \varepsilon \cdot \varepsilon$

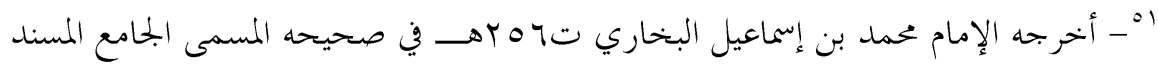
الصحيح المختصر من أمور رسول الله صلى الله عليه وسلم وسننه وأيامه، طبعة دار طوق النجاة،

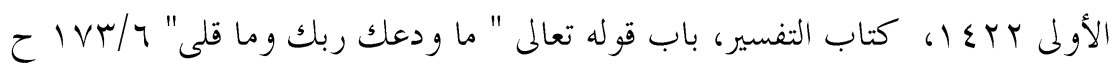

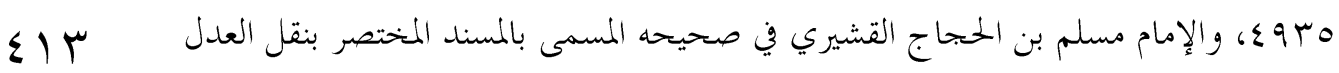
عن العدل إلى رسول الله صلى الله عليه وسلم، تحقيق محمد فؤاد عبد الباقي، ط دار إحياء

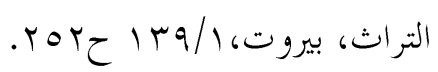
$1000 / r$ /

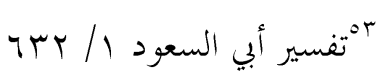

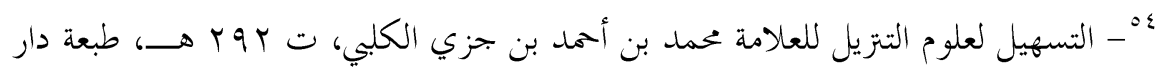

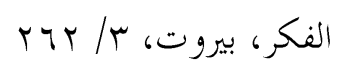

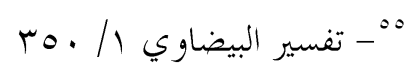
Tه- تفسير القر آن الحكيم الشهير بتفسير المنار للشيخ محمد رشيد رضا، طبعة دار المنار ، الطبعة

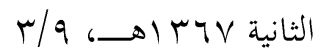
Vه - زاد المسير في علم التفسير لإمام أبي الفرج جمال الدين عبدالرحمن بن علي بن محمد

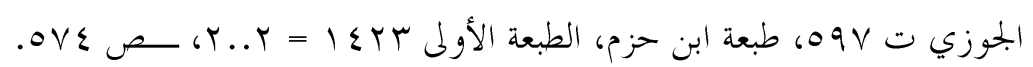

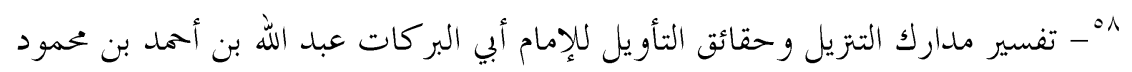

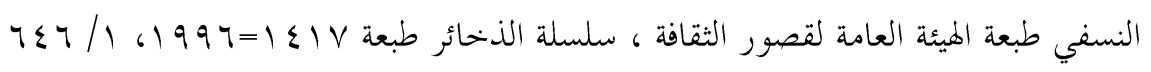

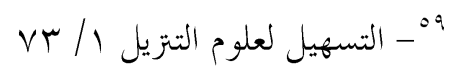




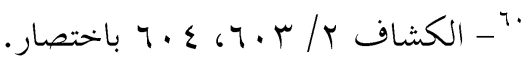

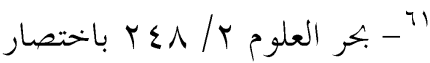

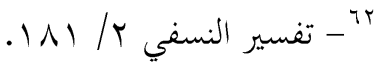

ז'الانتماء في ظل التشريع الإسلامي ص • س، اب باختصار.

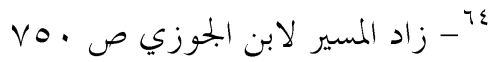

Pro

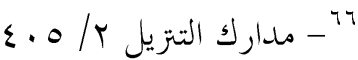

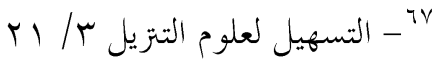

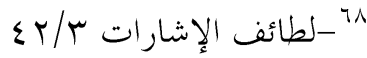

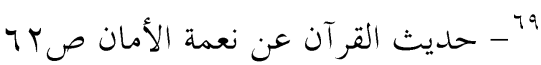

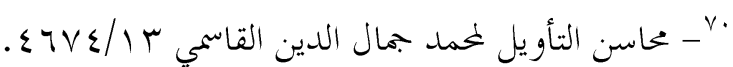

1 - تفسير القر آن العظيم لأبي الفداء عماد الدين اسماعيل بن كثير بن بن ضوء بن كثير الدمشقي ت عV VW]، تخريج محمود بن الجميل - وليد محمد سلامة - خالد محمد عثمان،

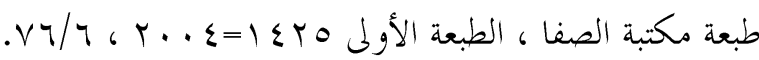

$$
\begin{aligned}
& \text { TVN/T }
\end{aligned}
$$

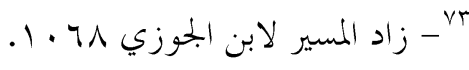

$$
\begin{aligned}
& 7 \text { ¿ }
\end{aligned}
$$

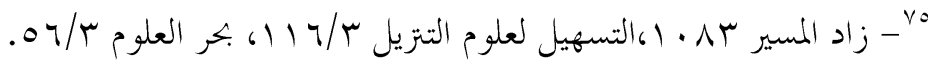

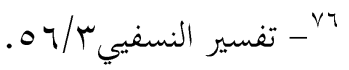

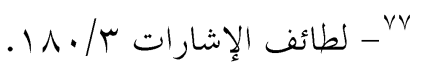

$$
\begin{aligned}
& \text { - - تفسير النسفي ب/ع · 1. }
\end{aligned}
$$

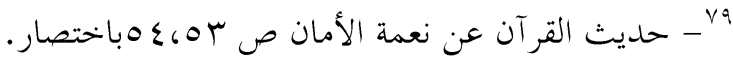

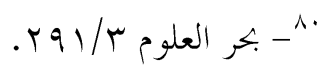

ا^- تفسير القر آن العظيم لأبي الحسن علم الدين علي بن محمد بن عبد الصمد السخاوي

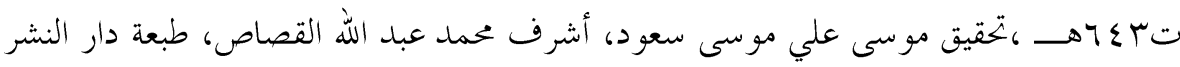

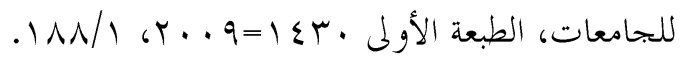




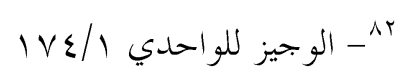

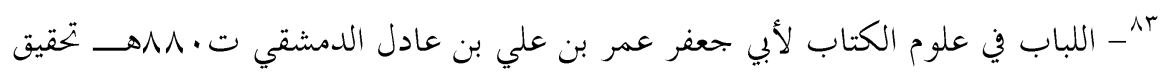
عادل أحمد عبد الموجود - على محمد معوض - مشار كة محمد سعد رمضان - محمد متولي

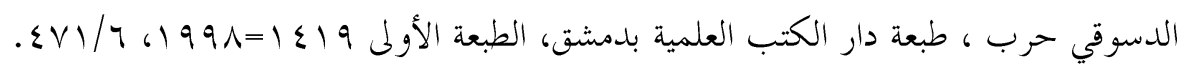

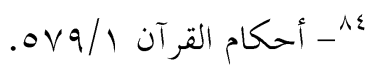

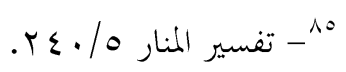

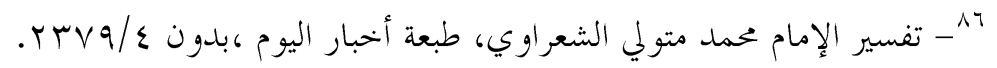
.

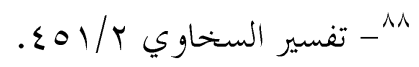
9^- البحر المديد في تفسير القرآن المجيد لأبي العباس أحمد بن محمد بن المهادي بن عجيبة

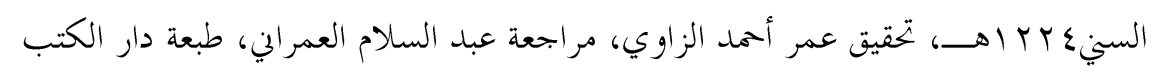

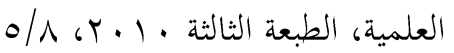

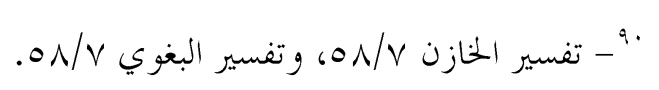

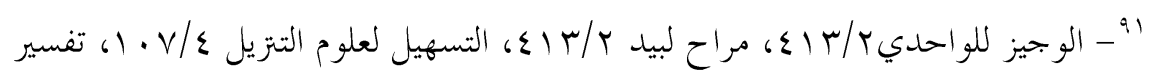
القرآن العظيم لأبي عبد الله محمد بن عبد الله بن أبي زمنين تو 9 سهــ، تحقيق د. أبي عبد الله حسين بن عكاشة - محمد بن مصطفى الكتبي، الطبعة الأولى rr|

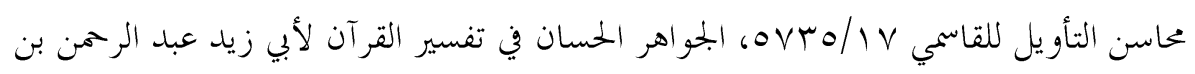
محمد بن مخلوف الثعابي المالكي ته م متحقيق علي محمد معوض - عادل أحمد عبد الموجود

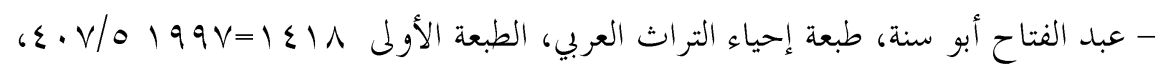

$$
\begin{aligned}
& \text { تفسير أبي السعود ه / . . م. } \\
& \text { Vo/7 - الكشاف } \\
& \text { r r - التحرير والتنوير }
\end{aligned}
$$

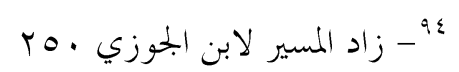

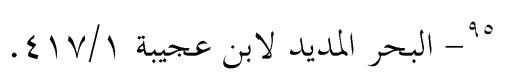

$$
\begin{aligned}
& \text { 999 - مراح لبيد / / / } 1 \text { باختصار يسير. }
\end{aligned}
$$




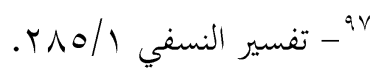

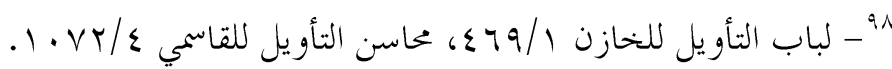

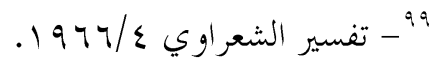

”. - الخرر الوجيز في تفسير الكتاب العزيز لأبي محمد عبد الحق بن عطية الأندلسي

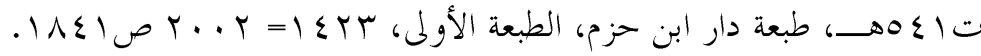

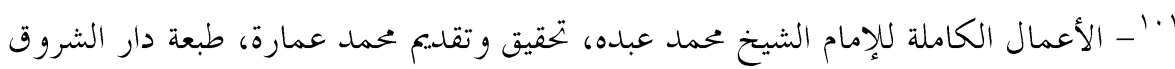

$1169 / \wedge r \ldots 9$ . r.r

ع •. - البحتمع الإسلامي للدكتور مصطفى عبد الواحد، طبعة المؤسسة العربية الحلديثة، الطبعة

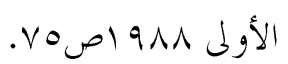

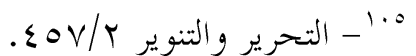
ب.

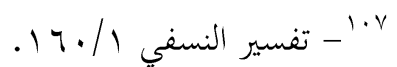

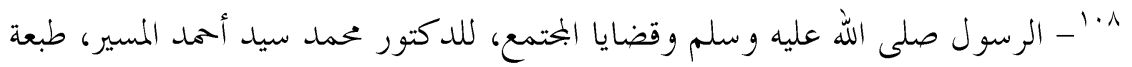

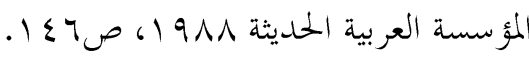

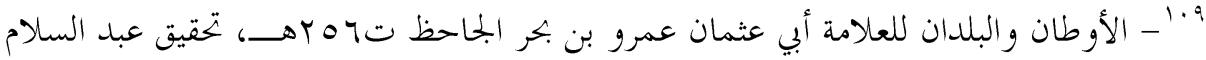

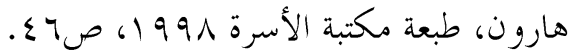
. 'l' - أنوار التزيل وأسرار التأويل للإمام أبي سعيد ناصر الدين عبد الله بن عمر بن محمد

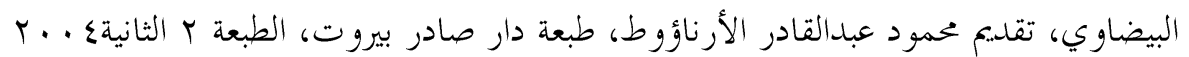
$.1 \% 0 / 16$

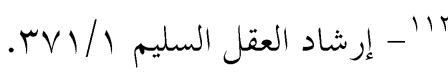

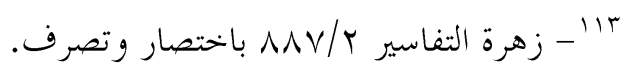
ع 'ا -در اسات إسلامية في العلاقات الاجتماعية والدولية، للدكتور محمد عبد الله دراز، طبعة

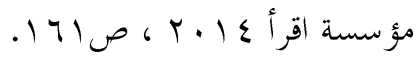


الوطن بين هدي القرآن وضلالات الأفهام

110

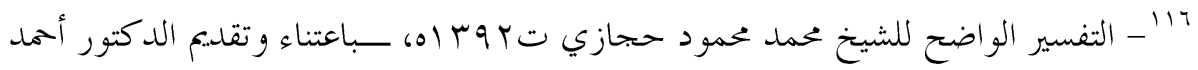

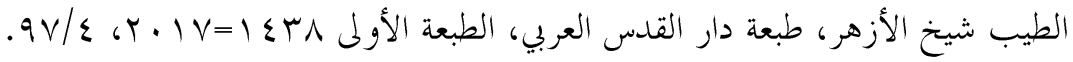

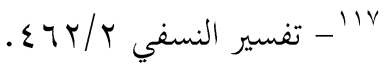

111 - التفسير الواضح ب/

.

•

哥.

ت إ)

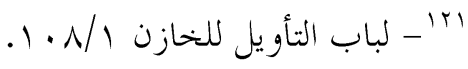

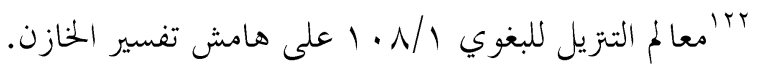

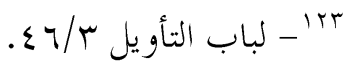

\&) $V$

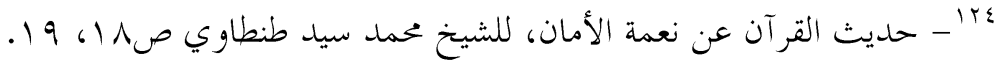

3
$\frac{3}{0}$

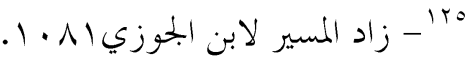

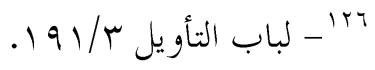

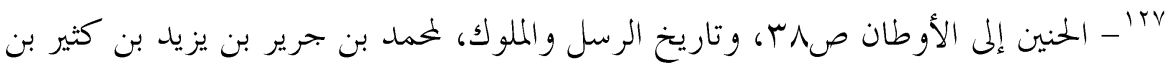

غالب الآملي، أبي جعفر الطبري ت · اسهــ، طبعة دار التراث - بيروت، الطبعة الثانية -

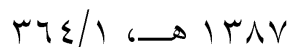

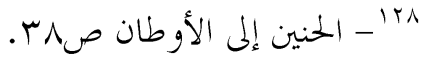

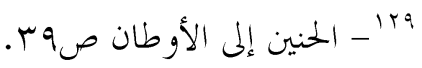




\begin{tabular}{|c|c|c|c|}
\hline الصفحة & موضوع البحث & اسهر الباحث & م \\
\hline 9 & 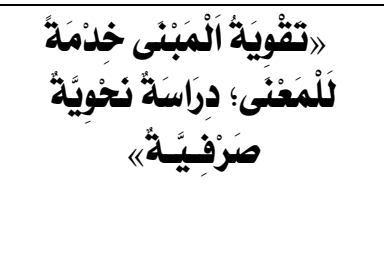 & 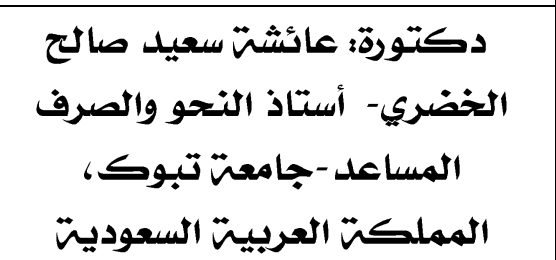 & 1 \\
\hline$n$ & 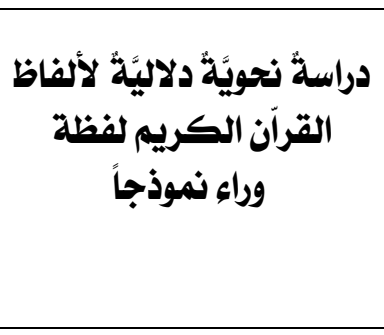 & 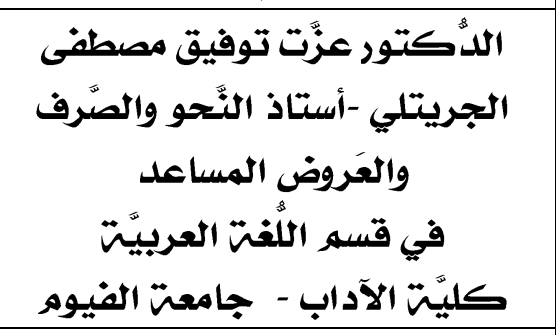 & 2 \\
\hline 174 & حذف اليايه في اللَّرس اللُّوي & 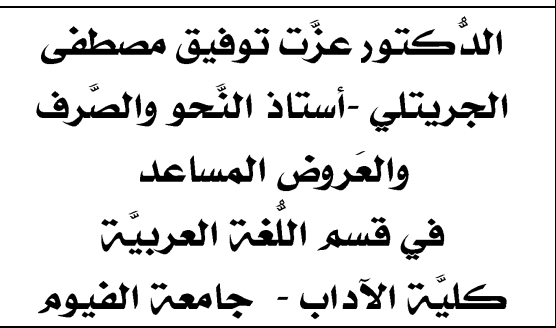 & 3 \\
\hline YAO & 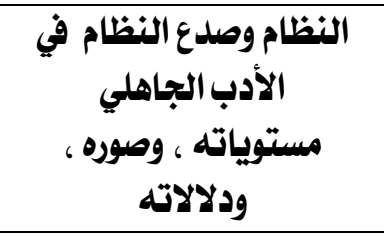 & 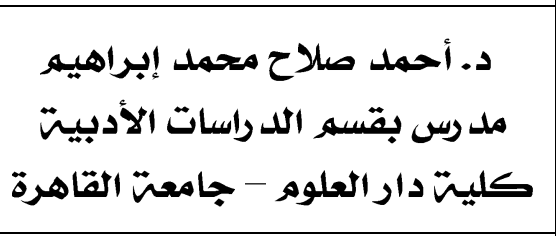 & 4 \\
\hline Frr & الوطن بين هدي الثرآن & 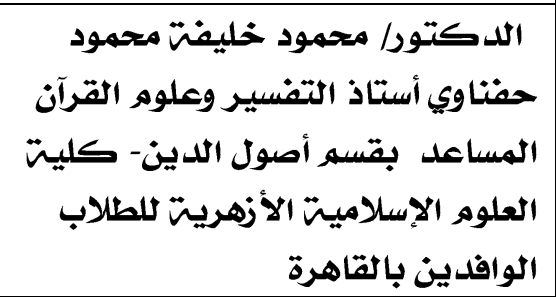 & 5 \\
\hline
\end{tabular}


رقم اليداع

$r \cdot 11 / 11001$

التزقيم الدولي

(ISSN PrOT - 9ATY) 